\title{
AVALIAÇÃO DE ALGUMAS PROPRIEDADES FÍSICO-QUÍMICAS DO CIMENTO AH PLUS PURO E ACRESCIDO DE HIDRÓXIDO DE CÁLCIO
}

MARCO ANTONIO HUNGARO DUARTE

Tese apresentada à Faculdade de Odontologia de Bauru, da Universidade de São Paulo, como parte dos requisitos para obtenção do grau de Doutor em Odontologia - Área de Endodontia. 


\section{AVALIAÇÃO DE ALGUMAS PROPRIEDADES FÍSICO-QUÍMICAS DO CIMENTO AH PLUS PURO E ACRESCIDO DE HIDRÓXIDO DE CÁLCIO}

\section{MARCO ANTONIO HUNGARO DUARTE}

Tese apresentada à Faculdade de Odontologia de Bauru, da Universidade de São Paulo, como parte dos requisitos para obtenção do grau de Doutor em Odontologia - Área de Endodontia.

(Edição Revista)

Orientador: Prof. Dr. Ivaldo Gomes de Moraes 
Duarte, Marco Antonio Hungaro

D85a

Avaliação de algumas propriedades físico-químicas do cimento AH Plus puro e acrescido de hidróxido de cálcio / Marco Antonio Hungaro Duarte. -- Bauru, 1999. 157 p.: il.; $31 \mathrm{~cm}$.

Tese. (Doutorado) - Faculdade de Odontologia de Bauru. USP.

Orientador: Prof. Dr. Ivaldo Gomes de Moraes

Autorizo reprodução total da referida Tese de Doutorado.

Marco Antonio Hungaro Duarte

Autor 


\section{DADOS CURRICULARES}

\section{MARCO ANTONIO HUNGARO DUARTE}

Nascimento

Filiação

$1988-1991$

$1992-1993$

$1994-1996$

$1997-1999$
26 de Abril de 1970 - JABOTICABAL/SP

Henrique Martins Duarte

Sheyla Therezinha Hungaro Duarte

Curso de Graduação em Odontologia na Faculdade de Odontologia de Bauru da Universidade de São Paulo.

Residência em Endodontia, no Hospital de Pesquisa e Reabilitação de Lesões Lábio-Palatais - USP.

Curso de Pós-Graduação em Endodontia, nível de Mestrado, na Faculdade de Odontologia de Bauru USP.

Curso de Pós-Graduação em Endodontia, nível de Doutorado, na Faculdade de Odontologia de Bauru USP. 
Dedico este trabalho

Aos meus paisHenrique e Sheyla, que sempre souberam educar e tratar com carinho os filhos, preocupando-se com os mesmos nos momentos dificeis $e$ vibrando com suas conquistas: se dedicando e esforçando sempre para tornar os sonhos dos filhos em realidade. 


\section{Dedico ainda este trabalho}

As minhas irmãs Márcia e Mônica e aos meus cunhados Max e Ivo, que sempre me trataram com carinho, preocupando-se também com meus passos e torcendo para o alcance dos meus objetivos.

Aos meus sobrinhos Vitor, Guilherme, Bruno e Flávio, com muito carinho.

À Daniela, pela paciência, ajuda e incentivo para a concretização deste trabalho. Tenho um amor e carinho todo especial por você.

\section{Dedico ainda}


Aos meus tios Juarez e Vera e aos meus primos Daniel e Felipe, pela amizade, carinho e incentivo, sempre me recebendo e tratando bem em sua casa, tratando-me como se fosse um filho. 


\section{Agradeço especialmente}

Ao Prof. Dr. Ivaldo Gomes de Moraes, pela paciência, amizade, conselhos e orientação precisa e segura na concretização deste trabalho. Sou eternamente grato pelo tratamento que tem para comigo, o considero mais que um mestre e orientador, o tenho como um pai, que sempre tem se preocupado com seu filho. Admiro-te muito e sempre o tenho como um exemplo a seguir.

Meu muito obrigado.

Um homem honesto é o mais nobre trabalho de

Deus.

Pope 


\section{Agradeço ainda}

\section{À Maria do Carmo, Fernanda, Renata e Guilherme pela amizade e solicitude com que sempre me trataram e me receberam bem e pela preocupação com os meus passos, me considerando como se fosse um membro da família.}

Sou eternamente grato. 
Aos Profs. Drs. Alceu Berbert, Clovis Monteiro Bramante, Norberti Bernardineli e Roberto

Brandão Garcia, pelos ensinamentos que foram essenciais para minha formação clínica, científica e didática e também, pela amizade e prestatividade para com minha pessoa.

Meu muito obrigado. 
Aos funcionários da Endodontia, Edimauro, $\boldsymbol{D}$.

Neide, Suely e Cleide, pelo carinho com que sempre me receberam e trataram e, também pelas constantes ajudas. Vocês foram importantes para minha formação.

Meu muito obrigado. 
Aos professores e amigos Mário Tanomaru Filho, Milton Carlos Kuga, Sylvio de Campos Fraga, José Carlos Yamashita e Eliane Cristina Gulin de Oliveira, pelo incentivo e ajuda para que esse sonho se tornasse realidade.

$\begin{array}{lrr} & \text { "O amigo fiel é forte } \\ \text { proteção; quem r o } & \text { quem } \\ \text { encontrou, achou um } & \\ \text { tesouro" } & & \end{array}$

Eclesiástico 


\section{Agradecimentos especiais}

Aos colegas de Doutorado, Ilan Sampaio do Vale, Eloi Dezan Junior, Alexandre Silva Bramante, Mônica Sampaio do Vale e Lilian Rosane Neuvald pela amizade e convivência agradável.

Ao amigo e irmão, Ilan Sampaio do Vale, pela amizade, troca de conhecimentos e pela colaboração na realização do teste de radiopacidade. O meu muito obrigado.

À Maria Vitória Lauris Fayad, pela ajuda na realização do teste de infiltração.

À Ana Cláudia Cardoso de Oliveira Demarchi, pela amizade e colaboração precisa na realização dos testes de pH e liberação de cálcio.

À Valéria da Biblioteca da FOB/USP, pela revisão bibliográfica deste trabalho.

Aos demais professores da pós-graduação, pelos ensinamentos, que foram importantes na minha formação.

Aos funcionários da Biblioteca da FOB/USP, pela grande atenção e solicitude durante a realização da pós-graduação.

Aos funcionários da pós-graduação da FOB/USP, pela grande atenção e carinho com que sempre me atenderam durante a pós-graduação. 


\section{Agradecimentos institucionais}

À Pós-Graduação, na pessoa do Prof. Dr. Luiz Fernando Pegoraro, pela oportunidade proporcionada para atingirmos mais um degrau da vida.

À Faculdade de Odontologia de Bauru/USP, na pessoa do Prof. Dr. Aymar Pavarini.

À Biblioteca da FOB/USP, pela colaboração direta no aprimoramento científico da minha pessoa.

À FAPESP (Fundação de Apoio a Pesquisa do Estado de São Paulo), pelo apoio fornecido para elaboração $e$ concretização deste trabalho. 


\section{SUMÁRIO}

LISTA DE FIGURAS .......................................................

LISTA DE TABELAS E ANEXOS ................................................

LISTA DE SÍMBOLOS E ABREVIATURAS ....................................

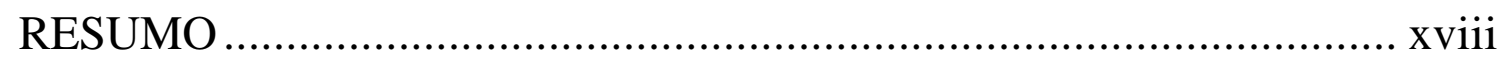

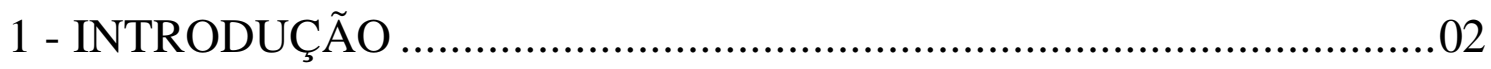

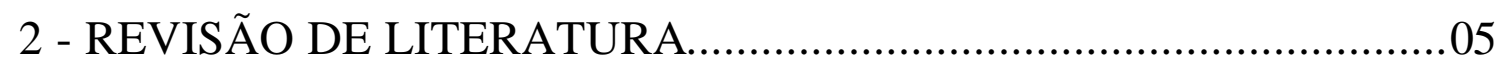

2.1 - Da análise do pH e liberação de íons cálcio ...................................05

2.2 - Da análise da infiltração apical................................................. 18

2.3 - Da análise de outras propriedades físico-químicas .........................49

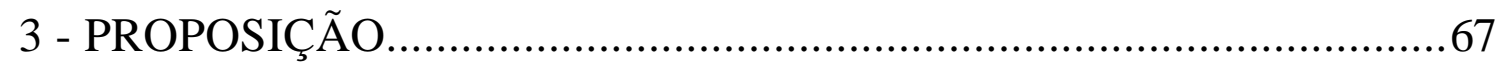

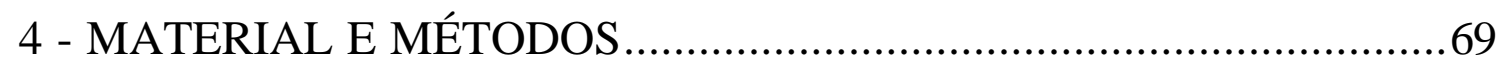

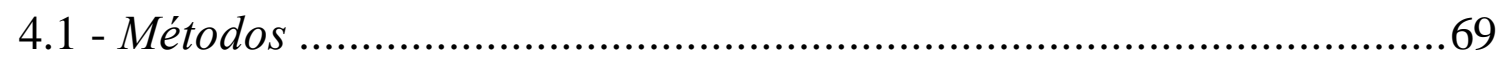

4.1.1 - Análise da infiltração marginal (capacidade seladora).................69

4.1.2 - Análise do tempo de presa ................................................... 71

4.1.3 - Testes de consistência dos cimentos (escoamento) ........................72

4.1 .4 - Determinação da radiopacidade ......................................... 72

4.1.4.1 - Confecção dos corpos de prova ............................................72

4.1.4.2 - Análise e determinação da radiopacidade por imagem digital ...73

4.1.5 - Análise do pH e liberação de íons cálcio .....................................74

4.1.5.1 - Leitura do $p H$........................................................... 75

4.1.5.2 - Leitura da liberação de íons cálcio.........................................75

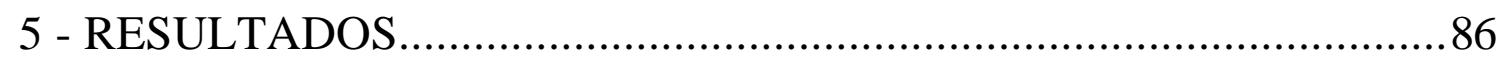

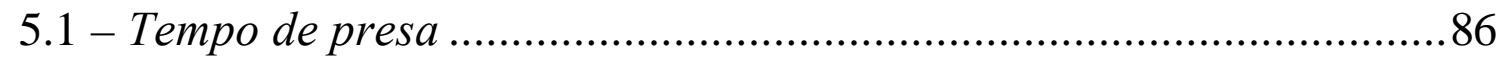

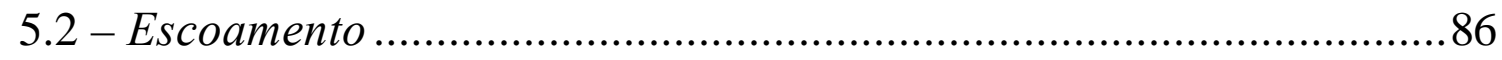

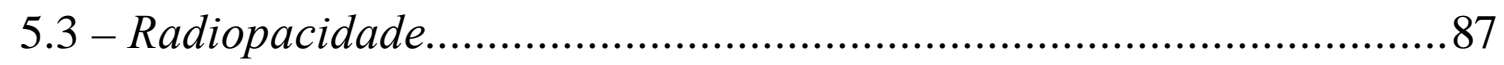

5.4 - Infiltração apical ...................................................... 91 


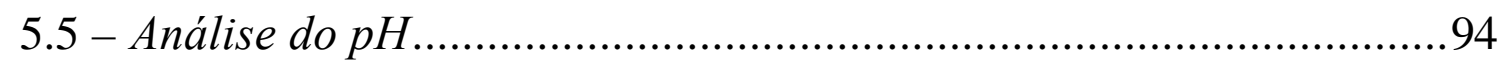

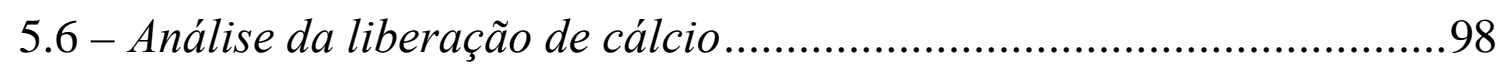

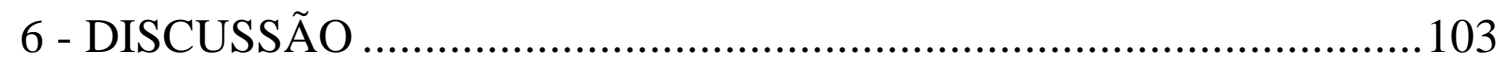

6.1 - Das metodologias empregadas ....................................................... 103

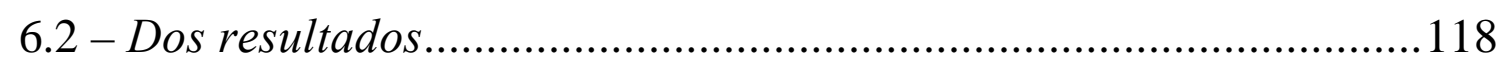

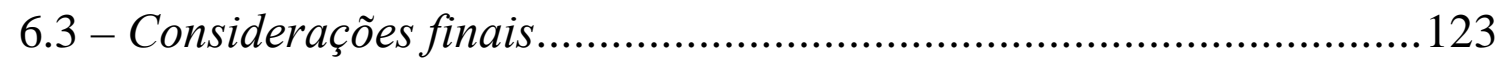

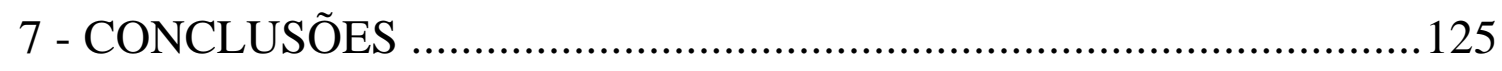

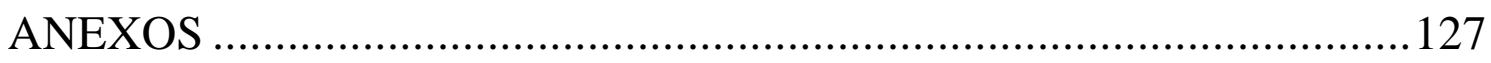

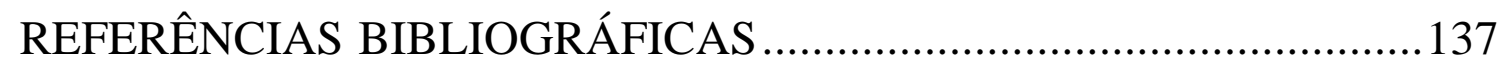

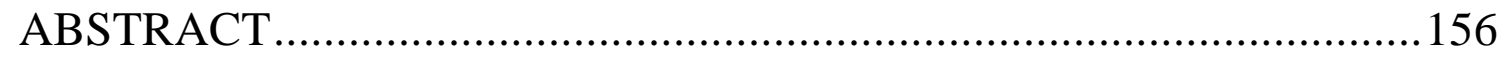




\section{LISTA DE FIGURAS}

FIGURA 1 - Cimento AH Plus puro e modificado.

FIGURA 2 - Hemisecções com os canais obturados com o AH Plus puro e utilizados para determinação da infiltração.

FIGURA 3 - Hemisecções com os canais obturados com o AH Plus acrescido de $5 \%$ de hidróxido de cálcio e utilizados para determinação da infiltração

FIGURA 4 - Hemisecções com os canais obturado com o AH Plus acrescido de $10 \%$ de hidróxido de cálcio e utilizados para determinação da infiltração

FIGURA 5 - Hemisecções com os canais obturados com o óxido de zinco e eugenol e utilizados para determinação da infiltração

FIGURA 6 - Placa óptica com o penetrômetro e os anéis contendo materiais posicionados para tomadas radiográficas

FIGURA 7 - Aparelho de imagem digital Digora empregado para determinação da radiopacidade.

FIGURA 8 - Espectrofotômetro empregado para medição do cálcio liberado.

FIGURA 9 - Representação gráfica das médias da radiopacidade, em mm de alumínio. .88

FIGURA 10 - Representação gráfica das médias das infiltrações marginais apicais, em milímetros, propiciadas pelos materiais estudados.

FIGURA 11 - Representação gráfica das médias do $\mathrm{pH}$ dos materiais estudados, em função do tempo

FIGURA 12 - Representação gráfica das médias da liberação de cálcio dos materiais estudados, em função do tempo. 99 


\section{LISTA DE TABELAS E ANEXOS}

TABELA 1 - Tempo de presa médio, em minutos, dos materiais estudados, em função das condições ambientais .86

TABELA 2 - Diâmetros maior e menor e as médias que correspondem ao escoamento dos materiais estudados.

TABELA 3 - Médias e desvios padrão da densidade radiográfica medida pelo Digora e do correspondente em $\mathrm{mm}$ de alumínio

TABELA 4 - Comparações individuais entre os grupos pelo teste de Tukey-Kramer, da radiopacidade, em densidade radiográfica

TABELA 5 - Comparações individuais entre os grupos, da radiopacidade em milímetro de alumínio pelo teste de Tukey-Kramer

TABELA 6 - Infiltração marginal apical medida em milímetros, propiciada pelos materiais em estudo

TABELA 7 - Comparação global da infiltração apical entre os grupos, pelo teste de Kruskal-Wallis

TABELA 8 - Comparações individuais da infiltração apical entre os cimentos, pelo teste de Miller

TABELA 9 - Médias e desvios padrão do pH dos cimentos estudados nos diferentes períodos de observação.

TABELA 10 - Comparações individuais do $\mathrm{pH}$ dos cimentos, pelo teste de Tukey-Kramer.

TABELA 11 - Comparações individuais entre os períodos de medição do $\mathrm{pH}$, pelo teste de Tukey-Kramer.

TABELA 12 - Comparações individuais intra-grupos do pH para verificar a interação tempo/cimento, pelo teste de Tukey-Kramer. 
TABELA 13 - Médias e desvios padrão da liberação de cálcio em mg\% dos cimentos estudados, nos diferentes períodos de observação

TABELA 14 - Comparações individuais da liberação de cálcio dos cimentos, pelo teste de Tukey-Kramer

TABELA 15 - Comparações individuais entre os períodos de medição da liberação de cálcio, pelo teste de Tukey-Kramer.

TABELA 16 - Comparações individuais intra-grupos, da liberação de cálcio, para verificar a interação tempo/cimento, pelo teste de Tukey-Kramer.

ANEXO 1 - Valores das densidades radiográficas para a escala de $\mathrm{mm}$ de alumínio do penetrômetro.

ANEXO 2 - Valores do pH do cimento AH Plus com 10\% de hidróxido de cálcio.

ANEXO 3 - Valores do $\mathrm{pH}$ do cimento $\mathrm{AH}$ Plus com $5 \%$ de hidróxido de cálcio.

ANEXO 4 - Valores do $\mathrm{pH}$ do cimento AH Plus puro

ANEXO 5 - Valores do pH do cimento óxido de zinco e eugenol....

ANEXO 6 - Valores da liberação de cálcio em mg\% do cimento AH Plus com $10 \%$ de hidróxido de cálcio

ANEXO 7 - Valores da liberação de cálcio em mg\% do cimento AH Plus com $5 \%$ de hidróxido de cálcio

ANEXO 8 - Valores da liberação de cálcio em mg\% do cimento AH Plus puro.

ANEXO 9 - Valores da liberação de cálcio em mg\% do cimento de óxido de zinco e eugenol. 


\section{LISTA DE SÍMBOLOS E ABREVIATURAS}

$\%$ por cento

$\mathrm{pH}$ potencial hidrogênico CRCS Calciobiotic Root Canal Sealer $\mathrm{Ca}^{++}$ cálcio iônico PMCC Para-mono clorofenol canforado OZE óxido de zinco e eugenol EDTA ácido etileno diamino tetracético G grupo ADA Associação Dentária Americana ISO Organização Internacional de Padronização $\mathrm{kV}$ kilovoltagem $\mathrm{Al}$ alumínio $\mathrm{mg}$ miligramas $\mathrm{mg} \%$ miligramas por cento $\mathrm{mL}$ mililitros ${ }^{0} \mathrm{C}$ graus Celsius \# diâmetro 


\section{RESUMO}

Algumas propriedades físico-químicas como radiopacidade, tempo de presa, escoamento, pH, liberação de cálcio e infiltração apical do cimento AH Plus puro ou modificado foram analisadas e comparadas in vitro æ̀ do óxido de zinco e eugenol. As modificações realizadas no AH Plus constaram do acréscimo de $5 \%$ e $10 \%$ de hidróxido de cálcio em peso. Para análise da radiopacidade, os cimentos foram acondicionados em anéis com $10 \mathrm{~mm}$ de diâmetro e $2 \mathrm{~mm}$ de altura de acordo com norma n 57 da ADA e a determinação dos valores se deram através do sistema de imagem digital Digora e depois foram convertidos em $\mathrm{mm}$ de Al. Para o teste de tempo de presa os cimentos, também, foram colocados em anéis metálicos e com auxílio de agulha Gilmore de $453,6 \mathrm{gr}$ de peso determinou-se o tempo de presa final. $\mathrm{Na}$ avaliação do escoamento, os cimentos foram preparados e $0,5 \mathrm{~mL}$ deles foram colocados sobre uma placa de vidro e, em seguida, outra placa com um peso totalizando 120 gramas foi colocada sobre o cimento e após 10 minutos mediu-se o maior e menor diâmetro do mesmo e a média dos dois foi o valor do escoamento. $\mathrm{Na}$ análise da infiltração apical dentes caninos humanos tiveram seus canais instrumentados e a seguir as superfícies externas impermeabilizadas, para então, proceder-se a obturação pela técnica do cone único com os cimentos em estudo. Na seqüência foram imersos em azul de metileno a $2 \%$ durante 7 dias. Finalizado esse período, os dentes foram removidos do corante, lavados, raspados seccionados e a infiltração do marcador foi determinada em microscópio óptico munido de ocular micrometrada. Para análise do $\mathrm{pH}$ e liberação de cálcio, os cimentos foram colocados em tubos com $1 \mathrm{~cm}$ de comprimento e $1 \mathrm{~mm}$ de diâmetro e, posteriormente, imersos em $20 \mathrm{~mL}$ de água deionizada. Nos períodos de $24 \mathrm{~h}, 48 \mathrm{~h}, 7$ dias, 14 dias e 30 dias, $4 \mathrm{~mL}$ da solução eram removidos e, então, se media o pH com auxílio de pHmetro e a liberação de cálcio através de espectrofotômetro de absorção atômica. Os resultados mostraram que o acréscimo de hidróxido de cálcio ao cimento $\mathrm{AH}$ Plus não interferiu significantemente na radiopacidade, não alterou o tempo de presa, melhorou o escoamento, principalmente com o acréscimo de $5 \%$, favoreceu 
significantemente o selamento apical e propiciou um $\mathrm{pH}$ mais alcalino, bem como liberação de ions cálcio. Com relação ao AH Plus puro, evidenciou-se um baixo selamento apical e um escoamento muito elevado. 
1 - INTRODUÇÃO 


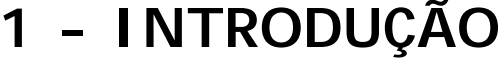

A busca de um material obturador que preencha as propriedades físicoquímicas ideais, tais como selamento, radiopacidade, tempo de presa e escoamento bem como as biológicas tem sido incessante, principalmente com respeito aos cimentos. A ânsia maior tem sido voltada para a obtenção de materiais que, principalmente tenham um efeito estimulador do processo de reparo, isto é, que biologicamente tenha um papel essencial na reparação das patologias apicais e periapicais.

O hidróxido de cálcio tem sido associado aos cimentos obturadores e cones de guta-percha, por ser uma substância que desempenha efeitos biológicos que contribuem, indubitavelmente, para o reparo apical e periapical, visto que o mesmo, por meio do $\mathrm{pH}$ alcalino e liberação de cálcio, atua em nível tecidual levando a efeitos bioquímicos que culminam na aceleração do processo de reparo (BINNIE;MITCHEL ${ }^{20}$, ESTRELA et al. ${ }^{41,43}$, SEUX et al. ${ }^{123}$ ).

BERBERT ${ }^{18}$, em 1978 associou hidróxido de cálcio ao AH26 e em um estudo em dentes de cães detectou uma melhora do comportamento biológico desse material.

MORAES $^{99}$, em 1984 estudando as características físicas do cimento AH26 e suas modificações, pelo acréscimo de hidróxido de cálcio, observou melhoras, principalmente no que se diz respeito ao selamento apical.

Um dos primeiros materiais que surgiram, comercialmente, contendo hidróxido de cálcio na composição foi o Sealapex. HOLLAND; SOUZA ${ }^{60}$ estudando esse material constataram resultados biológicos excelentes, comprovando o efeito positivo da presença de hidróxido de cálcio nos cimentos obturadores.

Outros estudos em dentes de macacos (TAGGER;TAGGER ${ }^{134}$ ), de cães (BERBERT ${ }^{18}$, TRONSTAD; BARNETT; FLAX ${ }^{141}$ ) e em subcutâneo de rato e porcos guíneas (OLIVEIRA et al. ${ }^{103}$, YESILSOY et al. ${ }^{152}$ ), principalmente utilizando o Sealapex têm confirmado o benefício da presença de hidróxido de cálcio nos 
materiais obturadores, inclusive à guta-percha, o que vem melhorar as características seladoras do material (HOLLAND et al. ${ }^{66}$ )

Através das modificações propostas por BERBERT, foi lançado no mercado o Sealer 26, e estudos com esse material têm demonstrado resultados satisfatórios $^{33,138}$.

Um novo cimento endodôntico, o $\mathrm{AH}$ Plus foi lançado no comércio recentemente em 1997, porém, o mesmo não possui em sua composição o hidróxido de cálcio e sim o tungstênio de cálcio.

Em estudo do comportamento biológico e selador desse cimento, ALMEIDA $^{8}$ observou bons resultados. Em clínica, na análise radiográfica dos casos obturados com este cimento, têm apresentado boa radiopacidade, porém sua consistência é um tanto fluída tendo-se observado extravasamentos do material em algumas obturações de canais com ele realizadas. Este fato fica difícil de ser controlado, já que o material é apresentado na forma de duas pastas de fluidez muito próxima. Partiu-se, então, da indagação de qual seria o efeito da adição do hidróxido de cálcio em pó ao AH Plus, sobre as suas propriedades físico-químicas e, conseqüentemente, até as biológicas. Paira a dúvida. 
1 - REVISÃO DE LITERATURA 


\section{2 - REVIS $\tilde{A} O \quad \mathcal{D A} L \mathcal{L}$ ERAT URA}

\section{1 - Da análise do pH e liberação de íons cálcio}

TRONSTAD et al. ${ }^{142}$ em 1981, determinaram in vivo as mudanças de $\mathrm{pH}$, pós-tratamento endodôntico com hidróxido de cálcio. Utilizaram macacos que tiveram alguns de seus dentes reimplantados e outros não e, posteriormente, trataram e preencheram os canais com hidróxido de cálcio. Decorridas 4 semanas, sacrificaram os animais e prepararam os dentes para análise do $\mathrm{pH}$ com o auxílio de marcadores. Verificaram que em dentes necrosados e sem tratamento, o pH do canal, dentina, cemento e ligamento periodontal variou entre 6 e 7,4. Dentes reimplantados e não reimplantados tratados com hidróxido de cálcio mostraram valores de $\mathrm{pH}$ de dentina circumpulpar entre 8 e 11 e na dentina próxima ao ligamento periodontal entre 7,4 e 9,6. Em dentes que apresentavam rizogênese incompleta, o pH da dentina, em sua totalidade, foi entre 8 e $10.0 \mathrm{pH}$ do cemento não foi influenciado pelo hidróxido de cálcio. No entanto, em áreas de reabsorção, encontraram um $\mathrm{pH}$ alcalino na dentina exposta.

ANTHONY; GORDON; DELRIO ${ }^{10}$ mediram o pH da pasta de hidróxido de cálcio quando os veículos foram o soro fisiológico, paramonoclorofenol canforado ou cresatina. Realizaram o estudo em três fases. $\mathrm{Na}$ fase I preencheram os canais com as pastas e os dentes foram imersos em soro fisiológico, medindo-se, posteriormente, o pH da solução. Na fase II a pasta foi colocada diretamente na solução, já na III o pó de hidróxido de cálcio foi colocado nos três veículos até a saturação para então medir-se o pH. Para as três fases, o $\mathrm{pH}$ foi determinado nos períodos de 6, 24, 48 e 72 horas e 1 e 2 semanas. Verificaram que o mais alto $\mathrm{pH}$ ocorreu quando o hidróxido de cálcio foi associado àsolução fisiológica e ao paramonoclorofenol canforado. A associação com cresatina ofereceu os piores resultados.

GORDON; ALEXANDER ${ }^{53}$ determinaram o pH da solução salina após 1 dia e 4 horas, 1 e 2 dias e 1 semana. Onde estavam imersas raízes dentárias que 
tiveram seus canais obturados com Sealapex, CRCS e Cimento de Grossman. Um grupo sem obturação foi utilizado como controle. A coroa foi selada com Cavit em todos os grupos. Verificaram que o Sealapex apresentou os valores mais altos, cujo pico chegou a 8,3 após 4 horas, diminuindo nos demais períodos. $O$ CRCS mostrou resultados mais baixos que o Sealapex no período de 1 e 4 horas, sendo, significantemente, superior ao grupo controle e cimento de Grossman. Nos demais períodos não houve diferença entre os valores de $\mathrm{pH}$ dos cimentos. $\mathrm{O}$ grupo controle (não obturado) apresentou valores, significantemente, menores nos períodos de 3 dias e 1 semana.

Em 1988, TAGGER; TAGGER; KFIR ${ }^{135}$ determinaram a liberação de íons cálcio e o pH dos cimentos Sealapex, CRCS e Hermetic, comparando com os valores apresentados pelo Life e Dycal, utilizados como controle. Empregaram para avaliação da liberação de íons cálcio, um analisador automático de cálcio calibrado pela titulação de E.G.T. $\quad$ No pH utilizaram um instrumento PBS 737. Os cimentos eram espatulados e colocados no interior de tubos de polietileno preenchendo-os totalmente. Imediatamente após o preenchimento, os tubos eram colocados em água destilada. Realizaram as medidas de pH após 15, 30, 45, 60, 75, 90, 105 e 120 minutos da colocação do tubo com o material na água destilada. Verificaram que a liberação de cálcio e o pH apresentados pelo Sealapex foi gradual e prolongada, a exemplo do Life e Dycal. Porém, após 60 e 75 minutos, respectivamente, as amostras de Life e Dycal se desintegraram. O CRCS praticamente não liberou cálcio e os valores de $\mathrm{pH}$ foram baixos, próximo ao neutro. Para o Hermetic, houve uma liberação grande de cálcio nos primeiros 15 minutos.

WANG; HUME ${ }^{144}$ também em 1988 determinaram in vitro a difusão de íons hidrogênio e íons hidroxila de vários ácidos e bases, através da dentina humana e constataram, com surpresa, que a difusão de íons hidrogênio forte foi muito vagarosa, quase inexistente, no período de 16 dias. A água tratada, empregada como controle, difundiu-se muito bem. Os íons hidrogênio de ácidos fracos (ácido cítrico e láctico) se difundiram rapidamente através da dentina, como ocorreu com os íons hidroxila do Dycal. Determinaram também a capacidade 
tampão da dentina e constataram que foi altamente efetiva ao ácido, sendo tal observação atribuída à capacidade tampão da hidroxiapati ta e outros componentes da dentina. O tamponamento de produtos alcalinos foi menor porém, ainda, apresentando um grau elevado. Concluíram que os íons hidrogênios de ácidos fortes penetram muito pouco na dentina devido àremoção imediata de íons da dentina e interação com tamponamento local. A capacidade tampão da dentina a produtos alcalinos pareceu ser mais limitada e pode ser mais rapidamente superada, permitindo a difusão de íons hidroxila.

Utilizando o cimento Dycal, SEUX et al. ${ }^{123}$ em 1991 analisaram in vitro a formação de microcristais de calcita em culturas de células. Verificaram que as células da polpa dental humana se agregaram e aderiram aos microcristais. Através da imunofluorescência e classificação imunológica observaram a alta afinidade de moléculas de fibronectina do soro para com os cristais. Notaram que em quatro semanas, as células em culturas tinham várias características de odontoblastos diferenciados. Concluíram que os achados, fortemente, suportam a importância dos cristais gerados da reação de compostos de hidróxido de cálcio com carbonato do meio e fibronectina, como fatores preponderantes no início da formação da barreira de tecido duro.

LEONARDO et al. ${ }^{84} \mathrm{em} 1992$, determinaram o pH e a liberação de íons cálcio produzido por vários produtos que contém hidróxido de cálcio e entre eles, os cimentos Sealapex e CRCS. Amostras de $1,5 \mathrm{~g}$ foram preparadas para cada $6 \mathrm{~mL}$ de água destilada, sendo 5 amostras de cada para análise do $\mathrm{pH}$ e 3 amostras para liberação de íons cálcio. Determinaram as medidas após 5 e 30 min, 1, 3, 24, 48 e 72 h e 7, 30 e 60 dias para o pH e 5 min, 72 h e 7, 30 e 60 dias para o $\mathrm{Ca}^{++}$. Verificaram que o Calasept apresentou resultado uniforme em todos períodos de tempo, enquanto que a pasta Calen e Calen + PMCC apresentaram elevação do pH até 24 horas, mantendo-se estáveis a partir de então. Para os cimentos, os valores foram menores após $5 \mathrm{~min}, 30 \mathrm{~min}$ e 1 hora, sendo que o CRCS apresentou menor valor. Na liberação de íons cálcio, o Sealapex mostrou valores ascendentes até 7 dias, com declínio aos 30 e 60 dias; já o CRCS apresentou menores valores e estabilizou-se a partir de 72 horas. 
LEONARDO et al. ${ }^{85}$ em 1993, prepararam biomecanicamente 50 incisivos centrais superiores extraídos, tencionando analisar a penetrabilidade, na dentina radicular, de diferentes materiais usados como curativos tópicos entre sessões. Avaliaram os seguintes materiais: no grupo 1, PMCC $(2,5-7,5)$ em cones de papel; no grupo 2, pasta Calen; no grupo 3, pasta Calen + PMCC; no grupo 4, pasta Calen + PMC; no grupo 5, pasta aquosa de hidróxido de cálcio. Pela análise estatística dos resultados, concluíram que os grupos 3, 4, 5 se difundiram mais na massa dentinária, enquanto que o PMCC levado aos canais através de pontas de papel, apresentou os piores resultados.

Também em 1993, NERWICH et al. ${ }^{101}$ determinaram o pH da dentina de dentes extraídos que tiveram seus canais preparados e preenchidos com pasta de hidróxido de cálcio. Realizaram a medida durante um período de 4 semanas, com auxílio de pHmetro e microeletrodos colocados em pequenas cavidades na dentina, interna e externamente ao canal, nos terços apical e cervical. Verificaram que o $\mathrm{pH}$ aumentou dentro de horas na dentina interna, tanto no terço cervical onde foi registrado $\mathrm{pH}$ de 10,8, como, no apical, com pH de 9,7. No entanto, foi necessários de 1 a 7 dias para que $0 \mathrm{pH}$ começasse a aumentar na dentina externa, alcançando um pico de 9,3 na dentina cervical e 9 na apical, depois de 2 a 3 semanas. Concluíram que os íons hidroxila derivado do curativo de hidróxido de cálcio, se difundem através da dentina radicular. A difusão é mais rápida e maior na região cervical. Concluíram, também, que os íons se difundem pouco quando a superfície radicular está intacta, isto é, sem perda de cemento.

TAMBURIC; VULETA; OGNJANOVIC ${ }^{137}$ no mesmo ano, determinaram o pH e liberação de íons cálcio de materiais que não tomam presa, sendo eles o Calcipulp, Calxyl red, Calxyl blue e Cinacanal, e materiais que tomam presa, Dycal Nu-cap e Reolit. Empregaram um potenciômetro para medida do pH e íons cálcio, após a difusão de vidro sinterizado. Efetuaram a avaliação após 30 min, 2, 4, 6, 8, 24 e 48 horas da imersão do material em solução. Verificaram que os materiais que não tomam presa liberaram significantemente mais íons cálcio e hidroxila do que aqueles que tomam presa. Com relação aos que tomam presa observaram 
maior liberação para o Dycal. Atribuíram a menor liberação dos que tomam presa àformação de salicilato de cálcio após mistura das pastas base e catalisa dora.

Também em 1993, WAKABAYASHI et al. ${ }^{143}$. introduziram pasta de hidróxido de cálcio dentro de um compartimento artificial colocado na orelha de um coelho e observaram o efeito da substância no tecido vascular, com auxílio de estereomicroscópio. Averiguaram durante 14 semanas. Constataram muitos precipitados na borda do tecido vivo após a dissolução de microvasos ao redor da pasta. Esses cristais aumentaram nas primeiras 48 horas. Decorrido uma semana, ficou evidenciada a revascularização, verificando capilares neoformados próximo ao precipitado, o qual tornou-se mais liso com o tempo. Os cristais permaneceram estáveis e biocompatíveis durante o período de observação. Observaram alto pico de cálcio e fósforo na camada externa do tecido mineralizado e alto conteúdo de cálcio na porção interna. Concluíram que o precipitado pareceu ter o potencial de induzir calcificação distrófica pela absorção de cálcio e fósforo do tecido.

LAGE-MARQUES et al. ${ }^{81}$, no mesmo ano, avaliaram a velocidade de dissociação iônica do hidróxido de cálcio quando associado a diferentes veículos (anestésico, óleo de oliva, água destilada, soro fisiológico e polietilenoglicol 400). Utilizaram um método constituído de um reservatório superior e outro inferior, separados por uma membrana, possibilitando assim, o monitoramento potenciométrico do $\mathrm{pH}$ até a saturação da solução contida na câmara superior. Os registros obtidos com medidas de $\mathrm{pH}$, referentes aos períodos de 10 a 1260 minutos, foram tabulados e a cinética da dissolução iônica comparada com o coeficiente angular das curvas do logaritmo de concentração de íon hidroxila em relação ao tempo de estabilização de cada grupo. Verificaram que a estabilização da amostra veículada com anestésico ocorreu em menor tempo (60 minutos), atingindo a melhor relação entre valor de liberação iônica em função do tempo. $O$ $\mathrm{pH}$ e concentração iônica foram maiores nos grupos da água destilada e soro fisiológico, porém, o tempo de estabilização apresentou-se significantemente superior, sendo $4 \mathrm{~h}$ e $30 \mathrm{~min}$ para água destilada e 8 horas para o soro fisiológico. Constataram, ainda, que o pior resultado ocorreu com o óleo de oliva. 
LENGHEDEN $^{83}$, também em 1994, testou a união e o crescimento de fibroblastos diploidais embrionários de pulmão humanos, e do ligamento periodontal quando cultivados em pH variando entre 7,2 e 8,4 e concentrações de cálcio entre $100 \mathrm{uM}$ e $20 \mathrm{mM}$, procurando assim, simular condições in vivo. Observou as reações em 1, 3, 6 e 24 horas e 1 semana. Comparou os resultados com $\circ$ controle onde $\circ \mathrm{pH}$ era de 7,5 e concentração de cálcio de $1 \mathrm{mM}$. Constatou que as células do ligamento periodontal eram mais suscetíveis à alterações do pH e concentração de cálcio em relação as células embrionárias diploidais de pulmão. Quando o pH estava acima de 7,8 ambas as células diminuíram significantemente em número. O crescimento foi mais prejudicado pelo $\mathrm{pH}$ e concentrações de cálcio do que a união. $\mathrm{O}$ autor conclui que os resultados ajudam a explicar porque a aplicação do hidróxido de cálcio em $\mathrm{pH}$ elevado como medicação intra-canal pode prejudicar o reparo periodontal, em áreas de superfície radicular, onde o cemento foi alterado pelo trauma ou tratamento periodontal, permitindo assim o acesso do medicamento até à superfície radicular.

BELTES et al. ${ }^{16}$, em 1995, testaram in vitro a citotoxidade de três materiais obturadores que contém hidróxido de cálcio, entre eles o Sealapex. Empregaram para a avaliação, células L929, BAK, 21C13. Após a presa, cobriram os cimentos com as células e determinaram, através de método quantitativo, a citotoxidade em 24, 48 e 72 horas. Verificaram que todos os materiais foram citotóxicos, porém o Sealapex apresentou a mais alta citotoxidade, causando uma diminuição significante na densidade celular. O CRCS apresentou resultados intermediários e o Apexit provou ser o menos citotóxico.

ECONOMIDES et al..$^{34}$, em 1995, testaram a biocompatibilidade tecidual em tecido conjuntivo de rato de quatro cimentos obturadores, sendo eles o AH26, Roth 811, CRCS e Sealapex. Colocaram os cimentos em tubo de teflons e implantaram subcutaneamente em ratos Wistar-Furth. Após os períodos de 7, 14 e 21 dias verificaram os animais, removeram os implantes, fixaram, prepararam histologicamente e avaliaram através do microscópio. Removeram o cérebro, fígado, rim e útero dos animais sacrificados no período de 10 dias e analisaram, 
em espectrofotometria de absorção atômica com chama e concentração de zinco e cálcio nesses órgãos. Os resultados mostraram que o AH26 no período de 7 dias foi o mais mutante, sendo que a reação diminuiu com o tempo. O Roth $811 \mathrm{e}$ Sealapex causaram moderada a severa reação, enquanto que para o CRCS a reação foi de média a moderada. $\mathrm{Na}$ análise do conteúdo de cálcio e zinco averiguaram que o CRCS e o Roth 811 induziram redistribuição de zinco, enquanto, que o AH26 levou àredistribuição de cálcio em alguns órgãos.

ESTRELA et al. ${ }^{42}$, em 1995, utilizando incisivos centrais superiores determinaram in vitro a difusão de íons hidroxila do hidróxido de cálcio quando misturado com polietilenoglicol 400, soro fisiológico ou anestésico. Mantiveram os dentes em atmosfera de nitrogênio a $36,5^{\circ} \mathrm{C}$ na ausência de luz. Em 10 dos 20 dentes de cada grupo, o cemento apical foi removido para averiguar a influência do mesmo na difusão de íons. Utilizaram para análise, um método colorimétrico para determinação da difusão, medindo nos períodos de 7, 15, 30, 45 e 60 dias. Verificaram que para o soro fisiológico e anestésico, o pH passou de 6-7 para 7-8 após 30 dias, permanecendo neste nível até 60 dias. Para o polietilenoglicol 400, a mesma alteração ocorreu em 45 dias, permanecendo também até 60 dias. Deduziram, também que a remoção do cemento não influiu na difusibilidade . Dentro do canal, o $\mathrm{pH}$ sempre foi acima de $12 \mathrm{em}$ todos os períodos.

SIQUEIRA JÚNIOR; FRAGA; GARCIA ${ }^{127}$ em 1995 testaram três propriedades físico-químicas, dentre elas $\mathrm{o} \mathrm{pH}$ proporcionado por cimentos obturadores que contêm hidróxido de cálcio (Sealapex, Apexit e Sealer 26). Como parâmetro de comparação, empregaram o Fill-canal (derivado do O.Z.E.). As outras duas propriedades testadas foram a seladora e a fluidez. Para o pH utilizaram um pHmetro digital, realizando a medição 30, 60 minutos e 7 dias. Verificaram que todos os materiais testados que contém hidróxido de cálcio alcalinizaram o meio. A análise da capacidade seladora mostrou não haver diferença entre os materiais. Quanto àfluidez, o Sealer 26 foi significantemente superior. Concluíram que os cimentos que contém hidróxido de cálcio possuem propriedades significantemente superiores aos cimentos de óxido de zinco e eugenol. 
Também em 1995, SIMON; BHAT; FRANCIS ${ }^{126}$ analisaram o pH e a liberação de íons cálcio proporcionados pelo hidróxido de cálcio quando manipulado com água destilada, soro fisiológico, propilenoglicol e paramonoclorofenol canforado, como veículos. Prepararam os canais de dentes recém-extraídos e preencheram-nos com as pastas em estudo, após impermeabilização da superfície externa dos dentes. Imergiram os dentes em 10 $\mathrm{mL}$ de solução fisiológica e efetuaram a leitura após 1, 2, 3, 4, 5, 7, 14 e 30 dias. Com relação ao $\mathrm{pH}$, verificaram maiores valores para 0 grupo do paramonoclorofenol canforado e água destilada e menores para o soro fisiológico e propilenoglicol. Estes foram estatisticamente menores em relação ao paramonoclorofenol canforado. Concluíram que o propilenoglicol possui qualidades mais desejáveis, devendo ser o veículo de escolha para agregar ao hidróxido de cálcio.

STAEHLE et al. ${ }^{131}$ em 1995, empregando um corante (vermelhocresol) verificaram a alcalinidade de dentes humanos quando estes foram preenchidos com pastas e cimentos contendo hidróxido ou óxido de cálcio. Averiguaram também a influência da remoção da Smear Layer na promoção da alcalinidade da dentina. Concluíram que a pasta Pulpdent, uma solução aquosa de hidróxido de cálcio produziu a maior alcalinização. A remoção da Smear Layer levou ao aumento da alcalinidade a localizações dentinárias distantes do canal. Um efeito menor foi mostrado pelo Sealapex e uma pasta com veículo oleoso (Gangrena Merz) sendo ambos, materiais indicados para obturação. Com a remoção da Smear Layer, estes dois materiais alcalinizaram moderadamente a dentina adjacente. Apenas o Apexit, outro cimento obturador, não foi capaz de alcalinizar nem a dentina adjacente. Afirmaram que a liberação de íons hidroxila não é apenas influenciada pela quantidade absoluta de hidróxido de cálcio, mas também por outros ingredientes que, variavelmente, inibem a liberação deste íon.

DUARTE $^{33}$, em sua dissertação de mestrado no ano de 1996, estudou in vitro o poder antimicrobiano e $\mathrm{opH}$ de materiais utilizados na rotina endodôntica. Os cimentos avaliados foram: Endomethasone; AH 26; Sealapex; Sealer 26; Sealer 26 acrescido de 5\% de hexametilenotetramina; Sealer 26 
acrescido de $10 \%$ de hexametilenotetramina e, também a pasta aquosa de hidróxido de cálcio. Para análise da ação antimicrobiana se empregou o método de difusão radial em placas ágara escavadas. $\mathrm{Na}$ determinação do $\mathrm{pH}$, os cimentos foram colocados em tubos possuindo $2 \mathrm{~mm}$ de diâmetro e $10 \mathrm{~mm}$ de comprimento e, então, imersos em água deionizada a $37^{\circ} \mathrm{C}$. As leituras foram realizadas após 24 e 48 horas e 7 dias do material espatulado, com auxílio de um pHmetro digital. Pela análise dos resultados constatou-se que o Endomethasone apresentou os maiores halos de inibição, seguido do AH26, Sealer 26 com 10\% de hexametilenotetramina, Sealer 26 com 5\% de hexametilenotetramina e Sealer 26. O cimento Sealapex e a pasta aquosa de hidróxido de cálcio não apresentaram halo frente aos microrganismos utilizados para o teste. Quanto ao $\mathrm{pH}$, a pasta de hidróxido de cálcio apresentou os maiores valores, diferenciando-se estatisticamente dos demais. Os cimentos que contém hidróxido de cálcio ou óxido de cálcio na composição apresentaram pH estatisticamente maiores que aqueles que não possuem essas substâncias.

ESBERARD; CARNES; DEL RIO ${ }^{38}$ em 1996, investigaram as mudanças de $\mathrm{pH}$ por longos períodos em cavidades preparadas na superfície dentinária de dentes extraídos após a obturação com guta-percha e diferentes cimentos contendo hidróxido de cálcio. Após a limpeza e preparo dos canais radiculares de 50 dentes humanos unirradiculados recém-extraídos, os mesmos foram divididos em cinco grupos. Em quatro grupos os dentes foram obturados com guta-percha e Sealapex, Sealer 26, Apexit ou CRCS, todos contendo hidróxido de cálcio. O grupo remanescente serviu como controle e não foi obturado. Prepararam cavidades na superfície externa vestibular da raiz, nos terços cervical e médio. Determinaram o pH nestas cavidades no início do experimento e 3,7,14,21,28,45,60,90, e 120 dias após a obturação. Observaram que $\mathrm{opH}$ da superfície radicular não se tornou alcalino quando os cimentos obturadores de canais com hidróxido de cálcio foram empregados. O padrão de $\mathrm{pH}$ verificado $\infty \mathrm{m}$ esses não foi diferente do grupo controle. Concluíram que os cimentos contendo hidróxido de cálcio, embora praticáveis para o uso como cimento obturador de canal, não produziram pH alcalino na superfície radicular, e 
se tal mudança estiver relacionada a tratamento de reabsorções radiculares externas, estes cimentos não contribuem para o tratamento.

ESBERARD; CARNES; DEL RIO ${ }^{37}$, no mesmo ano, determinaram o $\mathrm{pH}$ em cavidades preparadas na superfície radicular vestibular, nas regiões cervical, média e apical de dentes com canais preenchidos com pastas de hidróxido de cálcio. Realizaram a instrumentação em 40 dentes unirradiculados e prepararam cavidades com $1,5 \mathrm{~mm}$ de diâmetro e $0,75 \mathrm{~mm}$ de profundidade nas regiões já citadas, desse dentes. Dividiram os dentes em quatro grupos, sendo que um grupo serviu como controle, e os outros três foram preenchidos com pasta aquosa de hidróxido de cálcio, hidróxido de cálcio misturado com paramonoclorofenol canforado ou pasta Pulpdent. O acesso coronário e o forame apical foram selados com Cavit e cada dente foi estocado em um recipiente contendo solução salina isotônica. Determinaram o pH nas cavidades após $0,3,7,14,21,28,45,60,90$ e 120 dias. Os resultados indicaram que as pastas se difundiram através da dentina em todas as regiões durante o período experimental de 120 dias. O padrão de mudança do $\mathrm{pH}$ na superfície do dente foi similar em todas as regiões independente da pasta empregada. $\mathrm{O} \mathrm{pH}$ alterou-se de 7,6 para 9,5 no período de 3 dias, seguido por um leve declínio para 9,0 nos próximos 18 dias, e finalmente alcançando o $\mathrm{pH}$ acima de 10 no período experimental remanescente. A pasta Pulpdent, na região apical, foi a única exceção deste padrão, com um pH abaixo em relação ̀̀ outras pastas $(\mathrm{pH} 9,3)$. Estes resultados in dicaram que todas as pastas testadas, atingiram um alto $\mathrm{pH}$ na superfície radicular e esse foi mantido por um período de 120 dias.

ESTRELA; PESCE ${ }^{39}$, em 1996, implantaram, em tecido subcutâneo de cão, tubos de polietileno contendo hidróxido de cálcio misturado com soro fisiológico, anestésico e polietilenoglicol 400. Avaliaram a liberação de íons cálcio e hidroxila nos períodos de 7, 30, 45 e 60 dias. Utilizaram para análise, o método de condutometria por titulação do EDTA para análise química do cálcio. A liberação de íons hidroxila foi determinada por analogia com os íons cálcio; os quais estão em relação direta com o peso molecular do hidróxido de cálcio. Verificaram que os maiores valores de liberação de cálcio e hidroxila foram 
proporcionados pela associação com o anestésico, seguido do soro fisiológico e, por último, pelo polietilenoglicol 400. Este apresentou uma liberação mais lenta e gradual, atingindo o topo após 60 dias. Para o anestésico e soro, os maiores valores ocorreram em 45 dias.

PENICHE; SAMPAIO; COLLESI ${ }^{108}$, também em 1996, testaram o pH de pastas de hidróxido de cálcio quando o mesmo foi associado a seis veículos, sendo eles: cloridato de lidocaína com fenilefrina (Novocol), cloridato de prilocaína com felipressina (Citanest), lauril-sulfato de sódio (Endocris), paramonoclorofenol canforado, propilenoglicol e soro fisiológico. A análise foi feita imediatamente e, após 1, 24 e 48 horas da pasta imersa em $30 \mathrm{~mL}$ de água destilada. Constataram que $\mathrm{opH}$ manteve-se acima de $12 \mathrm{em}$ todas as pastas e nos quatro períodos avaliados, embora $\mathrm{o} \mathrm{pH}$ dos veículos sejam diferentes conforme também averiguado.

REHMAN et al. ${ }^{115}$, por meio de um estudo in vitro, determinaram a quantidade e duração da difusão de íons cálcio de um cimento obturador (Apexit) e uma pasta empregada como curativo (Rootcal) que contém hidróxido de cálcio. Utilizaram dentes extraídos, sendo que em alguns, o cemento foi removido, simulando reabsorção dentária. Em um grupo os canais eram obturados com Apexit e técnica da condensação lateral, no outro os canais foram preenchidos só com a pasta. Imergiram os dentes em água deionizada e mediram o cálcio na solução com auxílio de eletrodo seletivo para cálcio nos períodos de 1, 2 e 3 dias e 1, 2, 3, 4 e 8 semanas. Verificaram que a liberação de cálcio com a pasta Rootcal foi maior do que com o Apexit durante todo o período avaliado. A difusão de íons cálcio ocorreu tanto pelo forame, como pelos túbulos nas áreas de reabsorção simulada. Ela foi maior no forame para a pasta Rootcal, enquanto que para o Apexit elas foram semelhantes.

BELTES et al. ${ }^{16}$, em 1997, examinaram os valores de $\mathrm{pH}$ de vários compostos a base de hidróxido de cálcio usados como medicamento intra canal, durante um período de 5 dias. Testaram os seguintes materiais: Calasept, Calcicur, Calxyl azul, Calxyl vermelho, Reogan rápido, e Tempcanal. Observaram que todos os materiais prometiam uma rápida liberação nas primeiras 2 horas, 
alcançando um estágio constante posteriormente. Verificaram que os mesmos exibiram $\mathrm{pH}$ alcalino sendo que o Reogan rápido, Calxyl vermelho e Calcicur apresentaram os maiores valores. Averiguaram também que o $\mathrm{pH}$ final de cada composto correlacionou positivamente com a massa de fração de hidróxido de cálcio contida no composto.

ESTRELA; PESCE ${ }^{40}$, também em 1997, avaliaram quimicamente a formação de carbonato de cálcio proporcionada por pastas de hidróxido de cálcio formada pela associação com três veículos hidrossolúveis, apresentando diferentes características ácido-base, após a implantação de tubos de polietileno com as pastas em tecido subcutâneo de cão. Os três veículos testados foram o soro fisiológico, polietilenoglicol e anestésico, averiguando essa formação nos períodos de 7, 30, 45 e 60 dias. Empregando volumetria de neutralização por meio do uso de ácido hidroclorídrico para titulação, determinaram o carbonato de cálcio formado. Os resultados mostraram que para a pasta de hidróxido de cálcio com soro fisiológico a média de formação de carbonato de cálcio é praticamente inalterada após 30 dias. Para o polietilenoglicol 400, isto foi observado após 45 dias, sendo que os valores foram mais baixos em relação ao soro fisiológico e o anestésico. Para este último a média foi mais alta no período inicial de 7 dias, permanecendo inalterada nos demais períodos.

GUIGAND et al. ${ }^{58}$, em 1997, estudaram a penetração intra-tubular induzida por duas pastas, uma a base de óxido de cálcio e a outra a base de hidróxido de cálcio. Utilizaram dentes de porco que foram divididos em 3 grupos: O grupo A que serviu de controle, grupo $B$ que foi preenchido com a pasta a base de óxido de cálcio e o grupo $\mathrm{C}$, no qual foi utilizada a pasta àbase de hidróxido de cálcio. Após os períodos de 8, 15 e 21 dias examinaram as amostras utilizando várias técnicas microanalíticas e, conjuntamente, pela dispersão de elétrons de imagem em microscopia eletrônica de varredura. Averiguaram que o raio cálcio/fósforo foi mais alto para as amostras com óxido de cálcio. Também, as distâncias sobre qual o raio cálcio/fósforo aumentava, era maior para o óxido de cálcio. Os resultados de microanálise foram confirmados pela análise de dispersão de elétrons. 
SILVA et al. ${ }^{125}$, em 1997, testaram a ionização do hidróxido de cálcio de quatro cimentos obturadores de canal radicular, sendo eles o Sealapex, CRCS, Sealer 26 e Apexit. Os métodos empregados na avaliação foram a condutividade, o pH e a espectrofotometria de absorção atômica. Os cimentos foram espatulados e inseridos em tubos com $6 \mathrm{~mm}$ de diâmetro e $15 \mathrm{~mm}$ de comprimento. Após a presa e 48 horas de estocagem em um dessecador, 5 amostras de cada material foram colocadas em $50 \mathrm{~mL}$ de água destilada e, então, analisaram-se os dados após $0,1,2,4,6$ e 24 horas e 5, 15, e 30 dias de imersão. Os resultados mostraram que o Sealapex foi o cimento que demonstrou mais alto $\mathrm{pH}$, cálcio iônico em todos os períodos experimentais, seguido pelo CRCS, Apexit e Sealer 26.

ALAÇAM; YOLDAS; GÜLEN ${ }^{4}$, em 1998, examinaram a alteração de pH na dentina com 2 diferentes tipos de preparações de hidróxido de cálcio, sendo elas a associação de hidróxido de cálcio com água destilada ou hidróxido de cálcio com glicerina. Utilizaram 140 dentes unirradiculados cujos canais foram preenchidos com as pastas e então, a alteração de pH na dentina foi avaliada em diferentes espessuras de dentina e em diferentes períodos através da medição do $\mathrm{pH}$ no ambiente externo. Verificaram que em todas as espessuras de dentina a associação do hidróxido de cálcio com glicerina mostrou $\mathrm{pH}$ significantemente mais alto que a outra associação. Concluíram que a combinação hidróxido de cálcio + glicerina deve ser utilizada com curativo intra-canal.

HUANG; KAD ${ }^{67}$, também em 1998, compararam o nível de $\mathrm{pH}$ superficial de três tipos diferentes de cimentos obturadores após a mistura em vários intervalos de tempo, in vitro. Espatularam os cimentos de acordo com as instruções do fabricante e incubaram a $37^{\circ} \mathrm{C}$ e $100 \%$ de umidade por $1 \mathrm{~h}, 24 \mathrm{~h}, 5$ dias, 8 dias, 2 semanas, 3 semanas, 4 semanas, 5 semanas, 7 semanas. Calcularam o pH dos materiais nos vários períodos de tempo com o auxílio do pHmetro Twin. Verificaram que o cimento resinoso AH26 apresentou o pH ácido em todos os períodos. O cimento de hidróxido de cálcio (pulp canal sealer) demonstrou $\mathrm{pH}$ alcalino em todos os períodos analisados. $\mathrm{O}$ cimento a base de 
óxido de zinco e eugenol (canals) teve o pH ácido nos períodos de $1 \mathrm{~h}, 2 \mathrm{~h}$ e $24 \mathrm{~h}$, apresentando alcalinidade nos demais períodos analisados.

\section{2 - Da análise da infiltração apical}

GROSSMAN $^{54}$, em 1939, testou o selamento hermético de dez materiais seladores provisórios, frente a infiltração de solução corante, saliva com corante, e bactérias. Os materiais avaliados foram guta-percha, silicona temporária, cimento de oxifosfato de zinco e Pró Tem, sendo que esses materiais foram colocados sozinhos ou associados. Utilizou como corante o azul de metileno, e os materiais foram inseridos em tubos, ao invés de dentes. Observou que os materiais testados não são impermeáveis ao corante e àpenetração bacteriana. Em contato com saliva ocorreu menos infiltração. Averiguou também, que os cimentos contendo óxido de zinco e eugenol foram mais efetivos sob todas as condições, sendo os melhores, enquanto que os cimentos com oxifisfato foram os piores.

KAPSIMALIS; EVANS; TUCKERMAN ${ }^{72}$, em 1965, realizaram investigações procurando melhorar a qualidade das autorradiografias, visando também tornar mais precisa a interpretação dos resultados da penetração de isótopos radioativos entre material obturador e dente e também da permeabilidade de substâncias na estrutura dental. Como radioisótopos empregaram o $\mathrm{S}^{35}$, trítio, glicose tritiada e prolina tritiada, em concentrações variadas. Oscilaram, também, as emulsões e verificaram que as mesmas em placas de vidro fotográfica apresentaram um contato mais íntimo com o dente do que o filme radiográfico. Com isso, a técnica proposta usa um composto autorradiográfico, localizando a área exposta do dente pela passagem de uma combinação de luz refletida e transmitindo, através da placa de vidro sob grande aumento. Portanto, fotos em preto e branco e coloridas podem ser obtidas e o caminho e a profundidade da penetração do isótopo pode ser mais precisamente relacionada com a autorradiografia. Uma parte do dente de $3 \mu \mathrm{m}$ produziu autorradiografias mais contrastadas do que $1 \mathrm{~mm}$. Quanto àconcentração do radioisótopo, para o $S^{35}$ a 
melhor foi de $100 \mu \mathrm{c} / \mathrm{mL}$ e para a glicose tritiada foi de $500 \mu \mathrm{c} / \mathrm{mL}$. Concluíram que a concentração máxima e mínima do isótopo e tempo de processamento devem ser pré-determinados para produzir imagens mais confiáveis.

HOLLAND et al. ${ }^{62}$, em 1974, averiguaram in vitro por meio da penetração de solução de $I^{131}$, a capacidade seladora de cimentos obturadores de óxido de zinco e eugenol, Rickert, Alpha Canal, Piocidina e pasta de Wach. Empregaram 210 dentes unirradiculados, onde dez deles serviram como controle. Realizaram o preparo químico-mecânico dos espécimes e dividiram os dentes em função do material a ser utilizado, de sua consistência (fluido ou consistente), e da técnica de obturação de cone único e pela condensação lateral, sendo que para cada cimento se empregou quarenta dentes, sendo dez para cada subgrupo. Imediatamente após a obturação, os dentes foram imersos na solução de $1^{131}$ a $37^{\circ} \mathrm{C}$ por 24 horas. Após esse período os dentes foram lavados, imersos em resina e seccionados longitudinalmente. Posteriormente àsecção os dentes foram radiografados e as imagens projetadas com aumento de 35 vezes e então se determinou a infiltração com um paquímetro. Os resultados mostraram que houve uma interação significante entre a forma física do cimento e a técnica de obturação, bem como também entre a composição do material e a técnica de obturação. As menores infiltrações ocorreram com a pasta de Wach fluída pela técnica da condensação lateral, no cimento de Rickert consistente em ambas as técnicas e na fluída pela condensação lateral, e no Alpha Canal fluido e condensação lateral.

JACOBSON; VON FRAUNHOFER ${ }^{69}$, em 1976, descreveram um método eletroquímico utilizando resistência ométrica zero, que avalia a quantidade média de áreas permeáveis do sistema de canais radiculares. Utilizaram dentes unirradiculados que foram obturados pela técnica da condensação lateral e, posteriormente, impermeabilizados com um material borrachóide da junção cemento-esmalte até $3 \mathrm{~mm}$ do ápice. Colocaram, então, os dentes em uma solução de cloreto de potássio, e quando a solução infiltrou na obturação atingindo um metal colocado na porção coronária, esse se corroía e, então, se estabeleceu 
a média de infiltração. Verificaram que essa técnica estabelece uma média quantitativa de selamento apical.

PITTFORD ${ }^{110}$, em 1979, comparou o selamento apical proporcionado por cimentos ionoméricos experimentais, com cimentos encontrados no comércio, entre eles o AH26 e dois novos, o Spad e o Methode Z. Utilizaram dentes humanos, unirradiculados recém-extraídos que foram preparados, impermeabilizados e obturados com cone de guta-percha ou de prata e os cimentos em estudos. Após a realização das obturações imergiram os dentes em solução aquosa de eosina que foi o corante utilizado para marcar a infiltração. Após o período de 48 horas de imersão, os dentes foram removidos do corante, lavados e então seccionados no sentido longitudinal, fotografados e então com o auxílio de régua mediram a infiltração do corante. Os resultados mostraram que o AH26 foi o material que apresentou melhor selamento. Quanto aos cimentos ionoméricos, as formulações, Aspa IV SnO e Aspa IV selaram melhor, sendo que esse maior selamento foi nos grupos em que os canais foram obturados pela técnica do cone único. Os dois novos cimentos no mercados, Spad e Methode Z, apresentaram pobre capacidade seladora.

GOLDMAN et al. ${ }^{51}$, em 1980 , avaliaram a resistência de um polímero hidrofílico plástico (poly-HEMA) para a invasão bacteriana. Utilizaram um modelo que empregou bactérias com alta motilidade e uma solução indicadora para determinar a infiltração das bactérias. Os microrganismos utilizados no estudo foram o Proteus mirabilis e o Streptococcus sanguis. Verificaram que não houve alteração da cor do indicador após 42 dias. Concluíram que o poly-HEMA não permite a infiltração de microrganismos no modelo empregado. O Proteus mirabilis e o Streptococcus sanguis permaneceram viáveis por 4 dias em contato com o poly-HEMA. Concluíram ainda, que o modelo foi um método efetivo de testar a capacidade seladora de materiais obturadores, in vitro.

ALLISON; MICHELICH; WALTON ${ }^{6}$ em 1981 avaliaram a influência da adaptação do cone principal, no selamento apical em obturações endodônticas. Dilataram padronizadamente canais radiculares e os cones principais foram selecionados em função da análise visual e tátil. Efetuaram, então, radiografias e 
classificaram os cones como adaptados ou não. Posteriormente, obturaram as espécimes e as imergiram em solução de $\mathrm{Ca}^{45}$, e a microinfiltração foi detectada com autorradiografias. Verificaram que não houve diferença estatisticamente significante entre as obturações dos dentes que tiveram os cones adaptados ou não. Concluíram que o critério radiográfico para averiguação da adaptação do cone principal foi mais rigoroso do que o visual e tátil, e que a adaptação do cone principal, ou seja, obter o travamento, para se efetuar a radiografia, não é necessário para estabelecer melhor selamento apical.

DOUGLAS; ZAKARIASEN ${ }^{32}$ em 1981 desenvolveram e utilizaram um método espectrofotométrico para determinação do volume de infiltração apical para canais radiculares obturados. Empregaram dentes que foram preparados, obturados, impermeabilizados e imersos em corante azul de metileno a $2 \%$. Após o tempo apropriado de imersão no corante, o impermeabilizante foi removido, a superfície cementária limpa e então dissolveram os dentes em ácido nítrico diluído para que o corante retornasse dentro da solução. Utilizando o relacionamento linear existente entre a concentração do corante e suas leituras espectrofotometricamente correspondente, as soluções testes foram analisadas por intermédio do espectrofotômetro e se determinou a concentração do corante. Obtida a concentração do corante e volume das soluções testes, determinou-se, então, o volume da solução de azul de metileno a $2 \%$ dentro do canal obturado. Foi considerada a possibilidade de que a estrutura radicular e/ou a obturação poderia absorver seletivamente corante ou água. Se isto ocorresse, o volume de corante calculado estaria correto. Entretanto, estruturas radiculares e numerosos materiais obturadores de canais foram testados e nenhuma absorção seletiva foi detectada. Concluíram que este método volumétrico de determinar a infiltração tem sido aplicado em vários estudos de infiltração e os resultados observados oscilam de $0,002 \mathrm{~mL}$ a $0,193 \mathrm{~mL}$. O método é fácil de utilizar, está sujeito a mínimo erro, e provém determinação de volume de infiltração, além da medida linear.

ZAKARIASEN; DOUGLAS; STADEN ${ }^{153}$, no mesmo ano, analisaram o relacionamento entre a medida linear e volumétrica da infiltração apical. Empregaram oitenta raízes de dentes unirradiculados cujos canais foram 
instrumentados e, então, divididas em quatro grupos de 20 cada, em função da técnica de obturação utilizada obedecendo o seguinte: A - condensação lateral ativa; B - condensação lateral com eucaliptol; C - Eucapercha modificada; D Cloropercha modificada. Cada raiz foi impermeabilizada e seu ápice exposto a solução de azul de metileno a $2 \%$. Após a imersão no corante, determinaram a infiltração linear e volumétrica (Espectrofotometricamente) do azul de metileno. A média linear e volumétrica dos grupos foram: $A(7,65 \mathrm{~mm}$ e $0,024 \mathrm{~mL}) ; B(5,60 \mathrm{~mm}$ e $0,022 \mathrm{~mL})$; C $(11,20 \mathrm{~mm}$ e $0,087 \mathrm{~mL})$; $\mathrm{D}(12,10 \mathrm{~mm}$ e $0,058 \mathrm{~mL})$. Observaram diferença significante entre os grupos para ambos os método de avaliação. Nas comparações individuais entre os grupos verificaram que o método linear não apresentava diferença entre os grupos $C$ e $D$, enquanto que o volumétrico $O$ demonstrou. Porém, na comparação entre o A e o B o linear constatou diferença enquanto que o volumétrico não. O coeficiente de correlação entre os dois métodos foi de 0,44. Concluíram que a infiltração linear não é satisfatoriamente semelhante ànfiltração volumétrica.

MATLOFF et al. ${ }^{95}$ em 1982, compararam vários métodos utilizados para avaliação da infiltração marginal em obturações endodônticas. Empregaram 63 dentes unirradiculados que foram instrumentados e obturados padronizadamente. Os dentes foram, então, divididos em três grupos de vinte dentes que foram imersos em soluções contendo azul de metileno misturado com $\mathrm{Ca}^{45}$ ou uréia com $\mathrm{C}^{14}$ e albumina com $\mathrm{I}^{125}$, sendo mantidos nas respectivas soluções por 48 horas. Após esse período seccionaram os dentes e radiografaram com filme Royal $X-$ Pan. Determinaram a infiltração do radioisótopo medindo na radiografia e a infiltração do corante com auxílio de um calibrador. Os resultados mostraram que o corante não infiltrou mais que todos os radioisótopos. Quanto aos radioisótopos, a uréia com $\mathrm{C}^{14}$ penetrou mais que o $\mathrm{Ca}^{45}$ e a albumina com $\mathrm{I}^{129}$.

JOHNSON; ZAKARIASEN ${ }^{70}$, em 1983, avaliaram o selamento proporcionado por obturadores de guta-percha ou cone de prata em canais mesiais de molares, terminando no mesmo forame ou em forames distintos. Utilizaram raízes mesiais de primeiro e segundo molares inferiores cujos canais foram obturados, um pela técnica da condensação lateral, e o outro com cone de 
prata. Cada grupo foi dividido em dois subgrupos, em função dos canais armazenarem no mesmo forame ou em forames distintos. Após a obturação, imergiram os dentes em solução aquosa de azul de metileno a $2 \%$ em uma temperatura de $37^{\circ} \mathrm{C}$ por um período de 30 dias. Após esse período, as raízes foram descalcificadas em ácido nítrico e o grau de infiltração foi determinado com auxílio de espectrofotômetro onde se determinou o volume de corante infiltrado. Os resultados indicaram que não houve diferença estatisticamente significante entre os grupos estudados.

ORSTAVIK; ERIKSEN; BEYER-OLSEN ${ }^{106}$, no mesmo ano, mediram a adesão de cimentos obturadores, àdentina e àguta -percha e compararam esses resultados com o selamento proporcionado pelos mesmos materiais. Os cimentos testados foram: cloropercha; AH 26, Endomethasone e Proco-sol. Para testar a adesão utilizaram uma máquina de teste universal, impondo àmesma uma velocidade de $1 \mathrm{~mm} /$ minuto. A força $(\mathrm{N})$ na ruptura da união foi registrada e usada para calcular a força de união $\left(\mathrm{MN} / \mathrm{m}^{2}\right)$. Para averiguação da infiltração, empregaram pré-molares que foram, padronizadamente, instrumentados e obturados com cone e os cimentos em estudo. Para o AH 26, Endomethasone, $\mathrm{N}_{2}$ normal e Proco-sol efetuaram, também, a obturação apenas com cimento. Para medir a infiltração, realizaram secções transversais. Os resultados mostraram que o AH 26 exibiu maior adesão àdentina e àguta -percha, e apresentou infiltração maior que os cimentos de óxido de zinco e eugenol, que demonstraram adesões menores, principalmente àdentina. Concluíram que cuidados devem ser tomados quando se comparar adesão e infiltração.

PITT FORD ${ }^{111}$, no ano de 1983 , estudou a relação existente entre o selamento apical e a resposta tecidual proporcionados por cimentos endodônticos. Empregou os cimentos Aspa IV, Kalzinol, Poly F e Endoseal. Para avaliação histológica, utilizou cães beagle, realizando o tratamento endodôntico nos dentes incisivos e pré molares dos cães. Classificou a resposta inflamatória, após a realização dos cortes histológicos, em ausente, moderada ou severa. Para avaliação da infiltração apical, empregou a eosina como marcador da infiltração, imergindo os dentes no corante por 48 horas. Pela análise dos resultados o autor 
concluiu que é necessário o preenchimento do canal radicular com o material obturador, porém não necessita alcançar o selamento hermético. A escolha particular de um cimento endodôntico nesta investigação pareceu ser sem importância quando da análise da resposta tecidual. Concluiu, ainda, que a importância dos testes de infiltração in vitro foi sobre enfatizada no passado.

TAGGER et al. ${ }^{136}$ descreveram, no mesmo ano, um método melhorado para avaliação tridimensional da infiltração apical. Recomendaram a impermeabilização do dente com verniz ou parafina, com exceção do ápice. Quando do uso da parafina como impermeabilizante, o dente é imerso duas vezes em recipiente contendo a parafina aquecida a $60^{\circ} \mathrm{C}$. Após a impermeabilização, imergiram os dentes em solução aquosa de verde prociano brilhante por 4 dias a $37^{\circ} \mathrm{C}$. Findado esse período, os dentes foram lavados e, então, removeu-se o excesso de corante conjuntamente com o impermeabilizante. Realizaram, então, a desmineralização em ácido nítrico a $10 \%$ por 5 a 10 dias, efetuaram a lavagem em água corrente e, posteriormente, desidrataram os espécimes em álcool em concentração ascendentes de 70 a $96 \%$ e duas mudanças em álcool absoluto. Finalmente, transferiram os dentes para o metilsalicilato para realizar a clareação dos mesmos. Uma vez clareados, fotografaram os espécimes. Concluíram que o método é fácil de aplicar e permite, com auxílio de microscópio com lente micrometrada quantificar a infiltração ocorrida.

MADISON; ZAKARIASEN ${ }^{90}$ avaliaram, em 1984, o efeito do preparo para pino no selamento apical de dentes tratados endodonticamente. Instrumentaram e obturaram os canais radiculares de dentes humanos extraídos, utilizando, na obturação, a técnica da condensação lateral ativa. Realizaram, posteriormente, o preparo para pino imediatamente ou 48 horas após a obturação, utilizando três técnicas diferentes, sendo elas: calcadores aquecidos; lima e clorofórmio; brocas de Peeso. Após os preparos, imergiram os dentes em corante de azul de metileno a $2 \%$ e determinaram a sua infiltração linear ou volumetricamente. Os resultados demonstraram que não houve diferença estatisticamente significante entre as técnicas de remoção da guta-percha e também, entre os intervalos de tempo, nos dois métodos de avaliação. Houve uma 
correlação de $42 \%$ entre os dois métodos de análise, ou seja entre a mensuração linear e volumétrica.

ALEXANDER; GORDON ${ }^{5}$, em 1985, compararam o selamento apical de dois cimentos obturadores com hidróxido de cálcio, sendo eles o Sealapex e o CRCS com o selamento proporcionado pelo cimento de Grossman. Empregaram trinta dentes unirradiculados que foram instrumentados e posteriormente obturados pela técnica da condensação lateral, variando-se o cimento, obedecendo a seguinte ordem: Grupo: cimento de Grossman; Grupo II: Cimento Sealapex; Grupo III: Cimento CRCS. Os dentes foram colocados em um recipiente com algodão úmido e mantidos em um encubador a $37^{\circ} \mathrm{C}$ por seis dias para a presa dos materiais. Posteriormente, imergiram os dentes em solução aquosa de azul de metileno a $2 \%$ por a $37^{\circ} \mathrm{C}$ por 6 dias. Concluído o período, lavaram os dentes e seccionaram e avaliaram a magnitude de infiltração a um aumento de $12,5 \mathrm{X}$. Os resultados mostraram que o Sealapex foi o material que apresentou melhor selamento, seguido do cimento de Grossman, e os piores valores foi com o CRCS, inclusive se diferenciando estatisticamente em relação aos demais.

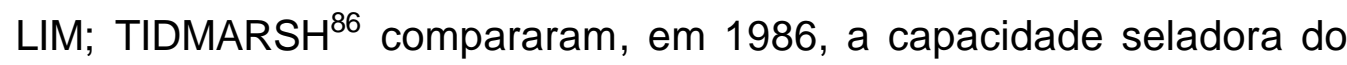
cimento Sealapex com a do AH26. Utilizaram trinta dentes unirradiculados, que foram divididos em dois grupos de 14 dentes, e dois utilizados como controle positivo e negativo. Realizaram a instrumentação dos dentes e a obturação pela técnica da condensação lateral. O método empregado para marcar a infiltração foi o eletroquímico e avaliaram durante 26 semanas. Os resultados mostraram que durante as primeiras 12 semanas o Sealapex apresentou significantemente melhor selamento que o AH26. Após esse período, não ocorreu mais diferença significante.

CERGNEUX et al. $^{28}$, no ano de 1987 , avaliaram in vitro a infiltração ocorrida em canais radiculares obturados, os quais tinham sido previamente limpos quimicamente pelo EDTA ou mecanicamente pelo ultra-som. Foram utilizados 60 dentes unirradiculados que inicialmente foram preparados biomecanicamente com hipoclorito de sódio. Então, os espécimes foram divididos em três grupos experimentais: no grupo I (grupo controle) os canais foram 
imediatamente obturados; grupo II (grupo ultra-som) os canais foram limpos com ultra-som antes da obturação; grupo III (grupo EDTA) os canais foram irrigados com EDTA por 4 minutos antes da obturação. A técnica de obturação foi a do cone único e o cimento ultilizado foi o óxido de zinco e eugenol. Todos os dentes foram, então, submetidos àinfiltração do corante de azul de metileno. Após a imersão seccionaram os dentes transversalmente e então avaliaram, estipulando uma escala com quatro pontos arbitrários. Os resultados mostraram que os dentes do grupo do EDTA apresentaram os menores valores de infiltração, seguido do grupo do ultra-som. O grupo controle apresentou os piores resultados. Concluíram que a remoção da Smear Layer é fundamental para obtenção de um melhor selamento em obturações endodônticas.

LEAL et al. ${ }^{82}$, em 1987, estudaram in vitro o selamento apical proporcionado pelos cimentos Sealapex, AH26 silver free e Fill canal, bem como averiguaram a influência do tempo de armazenagem na infiltração. Utilizaram noventa incisivos superiores que foram instrumentados, impermeabilizados e divididos em três grupos de 30 dentes cada, em função do cimento obturador. Após a obturação, quinze dentes de cada grupo foram imersos imediatamente no corante rhodamine B a $2 \%$ por 7 dias, enquanto que os outros quinze foram imersos em soro fisiológico por 30 dias e, posteriormente, colocados no mesmo corante por mais 7 dias. Concluídos os períodos, os dentes foram seccionados longitudinalmente e, então, avaliaram a magnitude da infiltração. Os resultados mostraram que o AH26 silver free e o Sealapex apresentaram os menores índices de infiltração enquanto que o Fill canal, os maiores. O tempo de armazenagem teve influência significativa sobre a infiltração.

MADISONS; SWASON; CHILES ${ }^{91}$, no mesmo ano, compararam a microinfiltração coronária nos canais radiculares de dentes obturados com gutapercha e Sealapex ou AH26 ou cimento de Roth. Concluindo as obturações, os dentes foram expostos àsaliva artificial por uma semana e, então, colocados dentro do corante, que foi a tinta Pelikan, para marcar a infiltração. Posteriormente, descalcificaram e clarearam os espécimes e, então, mediram linearmente a infiltração, desde a junção cemento esmalte, até à máxima 
penetração do corante. A análise estatística dos dados mostraram que o grupo do AH26 demonstrou significantemente mais infiltração do corante do que os outros grupos. Não houve diferença estatística entre o Sealapex e o cimento de Roth.

ZMENER $^{154}$ comparou, em 1987, a capacidade seladora de dois cimentos a base de hidróxido de cálcio, Sealapex e CRCS, com o selamento proporcionado pelo Tubli-seal, em diferentes períodos de tempo. Noventa dentes superiores, unirradiculados, foram preparados biomecanicamente e obturados pela técnica da condensação lateral com os cimentos em estudo. Concluída a obturação os dentes foram mantidos em $100 \%$ de umidade por 48 horas para a presa do material. Após esse período imergiu os dentes em solução aquosa de azul de metileno a $5 \%$ por diferentes períodos de tempo, sendo eles de 1 , 3 e 10 dias. Ao final de cada período, os dentes eram removidos de corante, lavados, seccionados longitudinalmente e, então, se realizava a medição da infiltração com auxílio de um estereoscópio munido de ocular micrometrada. Não houve diferença significante entre os materiais estudados, porém a infiltração aumentou significantemente com o tenmpo.

KERSTEN ${ }^{77}$ et al., em 1988, desenvolveram um método para produzir dentina artificial. Várias amostras foram produzidas e utilizadas para teste de infiltração. O material empregado consistia de $80 \%$ de hidroxiapatita e $20 \%$ de polietileno. Os blocos confeccionados foram obturados pelas técnicas da condensação lateral ativa e cone único empregando como cimento o $\mathrm{AH} 26$. Os espécimes foram, então, submetidos àinfiltração de ácido butírico (metabólito bacteriano de baixo peso molecular) no sentido coroa-ápice, sendo a infitração quantificada por meio de gás cromatográfico. Como parâmetro, empregaram raízes mésio-vestibulares de molares superiores que foram submetidas aos mesmos procedimentos. Observaram, pelos resultados que marcada diferença foi encontrada entre os dentes obturados pela técnica do cone único em relação à condensação lateral, que apresentou significantemente menos infiltração. Verificaram também, que as variações dos resultados foram menores nos canais produzidos com dentina artificial em relação aos dentes naturais. Concluíram que 
a dentina artificial produziu canais radiculares mais padronizados, sendo confiável para realização de testes de infiltração.

KUGA; MORAES; BERBERT ${ }^{80}$, também em 1988, avaliaram a influência do acréscimo de iodofórmio, nas proporções de 2:1 e 4:1 em volume, no selamento apical proporcionado pelo cimento Sealapex. Empregaram para isso, vinte e quatro caninos humanos que foram abertos de forma a se obter o livre acesso ao canal radicular e, posteriromente, tiveram seus forames padronizados até a lima $\mathrm{K} \# 35$, e instrumentados pela técnica escalonada regressiva. Realizaram, então, a impermeabilização dos dentes e a obturação pela técnica da condensação lateral passiva, utilizando o cimento Sealapex puro e acrescido de lodofórmio nas proporções citadas. Concluída a obturação, selaram a coroa dos dentes e imergiram os mesmos em solução aquosa de azul de metileno a $2 \%$ por sete dias. Após esse período, os dentes foram seccionados e analisados quanto à infiltração linear. Os resultados mostraram que o acréscimo de iodofórmio melhorou o selamento do Sealapex, inclusive na proporção de 2:1 observaram diferença significante em relação ao puro.

BAKHORADAR; BUI; WATANABE ${ }^{13}$, em 1989, compararam o selamento apical proporcionado por 5 cimentos obturadores de canais. Empregaram 60 raízes cujos canais foram instrumentados e, posteriormente, obturados pela técnica da condensação vertical, variando-se os cimentos, obedecendo aos seguintes grupos: I - Cimento ROTH's; II - AH26; III - Sealapex; IV - CRCS ; V - Nogenol. No grupo VI obturaram os canais com guta-pecha sem cimento. Selaram as coroas dos dentes e os incubaram a $37^{\circ} \mathrm{C}$ por 48 horas em umidade para a presa do material. Posteriormente, as raízes foram imersas em tinta da Índia, então, descalcificaram, desidrataram e incluíram as raízes em metilsalicilato para torná-las transparentes. Verificaram, com auxílio de microscópio, a infiltração. Os resultados observados foram: I - 0.45mm; II $0.277 \mathrm{~mm}$; III - 0.343mm; IV $-0.263 \mathrm{~mm}$; V $-0.336 \mathrm{~mm}$; VI $-2.31 \mathrm{~mm}$. Não evidenciaram diferença significante entre os cimentos. Porém no grupo sem cimento a diferença foi significante para com todos. 
GOLDMAN; SIMMONDS; RUSH ${ }^{53}$ em 1989 determinaram in vitro a influência de variáveis como a posição do dente e uso do vácuo, na infiltração apical. Na parte I dentes tiveram os canais preparados além do forame e, então, deixados abertos apicalmente, coronalmente e em ambos os lados. Verificaram que em todos os casos o corante não penetrou completamente. A única exceção foi quando ambos os lados foram deixados abertos e os dentes foram colocados dentro do corante em uma posição vertical. Na parte II, um defeito mensurável em um canal obturado foi deixado aberto apicalmente. Quando os dentes foram imersos no corante a penetração foi incompleta. Quando o ar foi removido pela bomba de vácuo antes da imersão a penetração foi total. Concluíram que estudos que não consideram as pressões tem a validade questionável.

KAUFMAN et al. ${ }^{74}$, em 1989, avaliaram o selamento proporcionado pelo Life e AH26 em obturações realizadas com compactação térmica da guta-percha pelo Engine Plugger. Utilizaram setenta raízes que foram preparadas e, posteriormente, divididas em função do grupo. Em um grupo de 20 o Life foi utilizado como cimento. O AH26 foi empregado em um outro grupo de 20. Vinte dentes foram obturados com guta-percha sem cimento. Os dez remanescentes serviram como controle. Utilizaram como corante a solução de azul brilhante Procion a $1 \%$, onde deixaram os dentes imersos a $37^{\circ} \mathrm{C}$ por 4 dias. Posteriormente, descalcificaram os dentes, clarearam e mediram a penetração do corante. Os resultados mostraram que a infiltração média para o Life foi de 0,575 $\mathrm{mm}$ e do AH26 de $1,025 \mathrm{~mm}$, e não houve diferença estatística entre os dois grupos estudados.

KERSTEN; MOORER ${ }^{76}$, em 1989, investigaram se diferentes tipos de obturações de canais previnem a infiltração de partículas de tamanho compatível com bactérias, moléculas proteicas amplas e também averiguaram a infiltração de azul de metileno, corante comumente usado e comparável com a infiltração de produtos bacterianos de baixo peso molecular. Utilizaram secções radiculares de 9 $\mathrm{mm}$ de extensão obtidas de incisivos e caninos. As raízes obturadas por diferentes técnicas foram montadas no centro de tubos fechados com membranas de borracha em ambos os lados. O reservatório coronário foi preenchido com uma 
solução de $1 \mathrm{mg} / \mathrm{mL}$ de latex, $4 \mathrm{mg} / \mathrm{mL}$ de endotoxina, $0,5 \%$ de ácido butírico; $0,1 \%$ ácido valérico e $0,1 \%$ de azul de metileno em água. Após os períodos de 1 e 2 semana o reservatório apical foi retirado, avaliados quanto àpresença de um dos componentes da solução colocada no reservatório coronário. Verificaram que a infiltração de partículas do tamanho de bactérias ou proteínas de alto peso molecular podem ser evitada quando na obturação se utilizou cimento com a gutapercha e pressão na obturação. A infiltração de ácido butírico mostrou ser comparável com a do azul de metileno e a microinfiltração destas substâncias não podem ser evitadas neste estudo.

$\mathrm{NEGM}^{100}$, em 1989, estudou o efeito da contaminação por sangue humano e umidade na habilidade de selamento de seis cimentos obturadores comumente usados. Os materiais testados - Tubliseal, Diaket, AH26, Nogenol, Roth, Endomethasone - foram usados em canais radiculares, com guta-percha condensada lateralmente. Os espécimes foram imediatamente imersos em sangue, solução salina ou mantidos secos por 2 horas. Todos os dentes foram sujeitados ao corante de azul de metileno a $2 \%$ (solução aquosa) por 1 hora. Uma comparação do selamento foi feita pela observação de penetração do corante ao redor do material obturador. Sob todas as condições, o Tubliseal exibiu a menor quantidade de infiltração, seguido pelo AH26. Não houve diferença significante na profundidade de penetração de corante entre Diaket e Tubliseal em condições secas e úmidas. Embora AH26, Nogenol, Roth e Endomethasone tenham mostrado comparáveis habilidades de selamento sob condições secas, a habilidade de selamento do AH26, Diaket foram superiores àvuelas do Nogenol, Roth e Endomethasone em contaminação pela umidade. Uma queda significante no selamento proporcionado pelo AH26, Diaket, Roth, e Endomethasone foi registrada quando estes materiais foram imersos em sangue. Por outro lado, esta condição não causou mudanças significantes na habilidade de selamento do Nogenol.

SPÄNGBERG; ACIERNO; $\mathrm{CHA}^{130}$ averiguaram, em 1989, a influência do vácuo nos estudos de infiltração, empregando penetração de corante. Empregaram raízes cujos canais foram instrumentados e, então, obturados com 
AH26. Imergiram uma certa quantidade das raízes em azul de metileno a $2 \%$ por uma semana e as outras raízes foram colocadas em uma câmara com 100 mtorr de pressão absoluta, para posterior imersão no corante, enquanto o vácuo era mantido. A magnitude da infiltração foi medida com esteriomicroscópio. Verificaram que o controle sem vácuo mostrou infiltração externa insignificante. No grupo em que o corante foi introduzido após a remoção do vácuo notaram penetração adequada do corante. Concluíram que o uso do vácuo vem tornar os resultados de infiltração de corante mais precisos.

MAGURA et al. ${ }^{92}$, em 1990, avaliaram a penetração de saliva em canais radiculares obturados, relacionando ao tempo de exposição, empregando para isso dois métodos, sendo eles o exame histológico e a infiltração de corante. Utilizaram 160 dentes anteriores humanos, que foram instrumentados até a lima Hedströen $n^{\circ}$ 60. Dez desses dentes permaneceram sem obturação, enquanto que os outros 150 foram obturados pela técnica da condensação lateral ativa com guta-percha e cimento de Roth. Cinquenta dentes obturados receberam restauração provisória coronária de $3 \mathrm{~mm}$ de IRM. Imergiram todos os dentes em $50 \mathrm{~mL}$ de saliva humana e incubaram à temperatura de $37^{\circ} \mathrm{C}$. A saliva foi substituída diariamente durante o experimento. Nos períodos de 2, 7, 14, 28 e 90 dias, 32 dentes eram retirados da saliva. Destes, dois não eram obturados e foram examinados quanto a penetração bacteriana realizando-se a cultura do terço apical. Dez dentes sem IRM foram imersos em tinta da Índia por dois dias para verificar a extensão de penetração salivar. Os outros vinte dentes, dez com e dez sem IRM foram descalcificados e corados em hematoxilina e eosina e pelo Brown\&Hopps, para determinar a infiltração salivar e bacteriana, histologicamente. Verificaram que a penetração de saliva visualizada histologicamnete foi significantemente menor do que a determinada pelo corante. A penetração de saliva após 3 meses foi significantemente maior do que nos quatro períodos anteriores.

KING et al. ${ }^{78}$, no mesmo ano, determinaram o selamento apical proporcionado por vários materiais obturadores retrógrados, sendo eles a gutapercha brunida a frio, amálgama, amálgama com verniz, Super EBA e Ketac- 
silver. Utilizaram dentes anteriores humanos que foram preparados e, posteriormente, confeccionadas as cavidades retrógradas. Os materiais foram, então, inseridos nas cavidades, sendo que a guta-percha sem cimento e o TERM serviram como controle positivo e negativo, respectivamente. Após as obturações retrógradas, os dentes foram levados àestufa a $37^{\circ} \mathrm{C}$ por 24 horas e $100 \%$ de umidade para presa dos materiais. Decorrido esse período, os dentes foram colocados em um aparelho com pressão de 10psi. Após esse procedimento ficaram imersos no corante para determinar-se a microinfiltração nos períodos de 24h, 1, 2 e 3 semanas, 1, 2 e 3 meses. Os resultados mostraram que o Ketacsilver apresentou significantemente menor selamento em todos os períodos analisados. Não houve diferença entre o Super EBA, amálgama e amálgama com verniz.

POLLARD; WELLER; KULILD ${ }^{112}$, também em 1990, realizaram a análise da infiltração in vitro em canais radiculares obturados com guta-percha e cimento, seguidos da imersão imediata ou mediata no corante, que foi a tinta da Índia. Empregaram sessenta dentes humanos unirradiculados que foram instrumentados e obturados com guta-percha e cimento. Cada grupo de 20 dentes foi então imerso no corante (tinta da Índia) imediatamente após a obturação, depois de 1 dia e após 7 dias. Após um período de imersão de 7 dias no corante, os dentes foram clareados até se obter a transparência e, então, realizaram a medida da infiltração, em estereomicroscópio. Observaram infiltração completa no controle positivo e nenhuma infiltração no controle negativo. Após a análise estatística dos dados não detectaram diferenças estatísticas entre os grupos em estudos.

PORKAEW et al. ${ }^{113}$, no mesmo ano, averiguaram a influência de resíduos de pastas de hidróxido de cálcio no selamento apical de obturações endodônticas. Utilizaram 66 caninos humanos extraídos, unirradiculados, que tiveram suas coroas removidas e os canais instrumentados até a lima tipo $\mathrm{K} 90$ a 1 $\mathrm{mm}$ aquém do comprimento da raiz. As raízes foram, então, divididas em quatro grupos de 18 dentes cada, sendo que em três grupos se empregou medicação intra-canal de hidróxido de cálcio, sendo eles o curativo de hidróxido de cálcio 
USP, Calasept e Vitapex, respectivamente, enquanto que o grupo controle foi obturado sem o uso prévio de curativo. Incubaram os dentes com curativo a $37^{\circ} \mathrm{C}$ durante 1 semana em $100 \%$ de umidade. Após esse período, os curativos foram removidos e os canais dilatados com a lima $K n=100$. Um dente de cada grupo foi submetido a análise em microscopia de varredura, enquanto que os demais foram obturados com guta-percha e cimento pela técnica da condensação lateral ativa. Imergiram as raízes em solução aquosa de azul de metileno a $2 \%$ por duas semanas e após esse período mediram a infiltração, linearmente com auxílio de microscópio e volumetricamente empregando espectrofotômetro. Encontraram uma correlação altamente significante entre a infiltração linear e volumétrica. Observaram também que os grupos que empregaram curativo tiveram a infiltração significantemente menor que o sem curativo, não havendo diferença significante entre os tipos de curativo.

TORABINEJAD; UNG; KETTERING ${ }^{139}$, também no ano de 1990, avaliaram a infiltração bacteriana in vitro em dentes obturados, porém não se realizando o selamento coronário. Quarenta e cinco canais foram instrumentados e, então, obturados com guta-percha e cimento (Cimento de Roth) pela técnica da condensação lateral ativa. Colocaram as porções coronárias da obturação em contato com Staphylococcus epidermidis e Proteus vulgaris. O número de dias requeridos para essas bactérias penetrarem em toda a extensão do canal radicular foi determinado. Verificaram que $50 \%$ dos canais radiculares foram completamente contaminados depois de 19 dias de exposição ao Staphylococcus epidermidis; enquanto que para ocorrer o mesmo índice de penetração para 0 Proteus vulgaris o tempo requerido foi de 42 dias.

HOLLAND et al. ${ }^{63}$, em 1991, analisaram a infiltração marginal após a obturação do canal de dentes humanos extraídos, com diferentes cimentos obturadores. Estudaram os cimentos: óxido de zinco e eugenol, Fill canal, Rickert, AH26, Sealapex, CRCS, New $B_{2}$ e um cimento experimental. Tencionando avaliar melhor quantitativamente a infiltração marginal ocorrida, os espécimes foram mergulhados em solução de azul de metileno em ambiente com vácuo, 24 horas e 75 horas após a obturação. Decorridos os períodos mencionados acima, 
seccionaram os dentes longitudinalmente e dimensionaram os resultados com o auxílio de uma ocular micrometrada submetendo, posteriormente, os dados à análise estatística. Notaram que os cimentos a base de hidróxido de cálcio e resina epoxi, apresentaram menor grau de infiltração que os a base de óxido de zinco e eugenol. Com relação ao tempo, as infiltrações foram significantemente menores no período de 24 horas.

LIMKANGWALMONGKOL et al. ${ }^{87}$, também no ano de 1991, avaliaram o selamento apical proporcionado pelos cimentos Apexit, Sealapex, AH26 e TubliSeal em obturações endodônticas pela condensação lateral. Empregaram 125 dentes que foram instrumentados pela técnica escalonada regressiva e, então, divididos em cinco grupos, em função dos quatro materiais estudados e um grupo que foi obturado sem cimento. Após a obturação os dentes foram mantidos a $37^{\circ} \mathrm{C}$ por 48 horas para a presa dos materiais. Concluído esse período, impermeabilizaram os dentes e os imergiram em solução aquosa de azul de metileno a $2 \%$, e colocaram em centrífuga por 3 minutos. Seccionaram transversalmente e observaram o nível de infiltração do corante. Os resultados mostraram que o AH26 infiltrou 0,82 mm; Apexit 1,67 mm, Sealapex 2,28 mm, Tubli-Seal 1,95 mm e sem cimento $8,37 \mathrm{~mm}$. Concluíram que o cimento deve ser empregado sempre com a guta-percha na condensação lateral e que o AH26 apresentou um selamento significantemente melhor do que os outros materiais.

LIMKANGWALMONGKOL; ABBOT; SANDLER ${ }^{88}$, em 1992, compararam a capacidade seladora dos cimentos Apexit, Sealapex, AH26 e TubliSeal quando utilizados na técnica da condensação lateral ativa. Empregaram cinquenta dentes unirradiculados, que foram preparados biomecanicamente pela técnica escalonada regressiva, tendo como agente irrigante o EDTA a 15\% com cetrimida associado ao hipoclorito de sódio a 1\%. Posteriormente, dividiram os dentes em 5 grupos de 10, em função do cimento em estudo e um grupo controle que foi obturado sem cimento. Concluída a obturação, estocaram os dentes a $37^{\circ} \mathrm{C}$ em $100 \%$ de umidade por 48 horas, e após esse período impermeabilizaram os dentes e os colocaram no corante de azul de metileno a $2 \%$ e centrifugaram por 3 minutos. Após esse período, seccionaram os dentes longitudinalmente e 
determinaram a magnitude da infiltração. Os resultados mostraram que a penetração do corante foi o seguinte: AH26: 0,48 mm; Apexit: 1,33 mm; Sealapex: 4,59 mm; Tubli-Seal: 5,58 mm e guta-percha sozinha 7,99 mm. A análise estatística demonstrou que o $\mathrm{AH} 26$ se diferenciou significativamente dos demais e o Apexit também filtrou significantemente menos que o Sealapex e o Tubli-seal. Não houve diferença significante entre o Sealapex e o Tubli-Seal.

SAHLI et al. ${ }^{116}$, no mesmo ano, avaliaram o selamento apical proporcionado por vários cimentos obturadores utilizando um novo método baseado no uso de um radioisótopo e uma técnica de detecção externa. Empregaram 150 dentes unirradiculados que foram instrumentados e, posteriomente, divididos em seis grupos experimentais e dois grupos controles em função dos cimentos a serem utilizados, sendo dois a base de óxido de zinco e eugenol, dois de resina e dois de hidróxido de cálcio, sendo que para o controle positivo só se empregou guta-percha, e o controle negativo teve o forame selado com verniz. A técnica utilizada na obturação foi a condensação lateral e uma vez obturados os dentes e após a presa dos cimentos, imergiram os ápices radiculares dos espécimes em uma solução contendo o radioisótopo metaestável TC ${ }^{99}$. Verificaram pelos resultados, que nenhuma infiltração ocorreu no controle negativo. Houve uma ampla diferença estatística entre os grupos experimentais e o controle positivo. O melhor selamento ocorreu com o Sealapex que se diferenciou estatisticamente dos demais. O AH26, Tubli-seal, Diaket não se diferenciaram entre si, porém, foram estatisticamente superiores ao CRCS e Endomethasone que demonstraram os piores resultados.

HOLLAND et al. ${ }^{64}$, em 1993 avaliaram a influência dos resíduos de hidróxido de cálcio no selamento proporcionado pelas obturações endodônticas. Empregaram oitenta dentes humanos extraídos que foram preparados biomecanicamente recebendo ou não o hidróxido de cálcio como curativo de demora por uma semana. Após removerem o hidróxido de cálcio, por diferentes procedimentos, obturaram os dentes pela técnica da condensação lateral e posteriormente, mergulharam os espécimes em azul de metileno a $2 \%$, em ambiente com vácuo. Decorrido 24 horas, partiram os dentes longitudinalmente e 
avaliaram as infiltrações marginais, submetendo os dados a análise estatística. Verificaram que o emprego do hidróxido de cálcio determinou significante melhora na qualidade do selamento marginal da obturação de canal e que esse efeito persiste após o emprego de diferentes procedimentos para a remoção do material.

STARKEY; ANDERSON; PASHLEY ${ }^{133}$, no mesmo ano, estudaram o efeito do $\mathrm{pH}$ do corante azul de metileno a $2 \%$ na infiltração apical. Empregaram 84 raízes de dentes humanos extraídos que foram preparadas e obturadas e, posteriormente, tiveram seus ápices secionados para, então, serem confeccionadas cavidades retrógradas que foram preenchidas com amálgama ou material restaurador endodôntico temporário. Após a realização das obturações retrógradas, imergiram os dentes em solução aquosa de azul de metileno a $2 \%$ com pH controlado de 1, 2, 3, 5, 7 ou em azul de metileno a $2 \%$ em água deionizada tamponada. Após a imersão no corante por 7 dias a $37^{\circ} \mathrm{C}$, seccionaram as raízes e averiguaram a infiltração ocorrida. Os resultados demonstraram significantemente menos infiltração do corante no $\mathrm{pH} 1$ e 2 para o grupo do amálgama. Todos os outros grupos do amálgama e todos do material restaurador endodôntico temporário não apresentaram diferenças significantes atribuíveis ao pH. O material restaurador endodôntico temporário apresentou significantemente menos infiltração do que o amálgama em todos os pHs. Observaram, também, um efeito tampão significante da estrutura radicular no corante.

SCHUURS et al. ${ }^{121}$, em 1993, descreveram os fatores relacionados à estatística que determinam o tamanho adequado da amostragem na realização de estudos. Apresentaram exemplos de cálculo de poder de teste. Analisaram o poder de teste da maioria dos estudos de infiltração e observaram que quase $2 / 3$ apresentavam 10 ou menos amostras por grupo e em torno de $90 \% 20$ ou menos. Portanto, comprovaram que menos do que a metade apresentava um poder de teste adequado (convencionalmente 80 ou mais). Relataram que precauções são necessárias na extrapolação dos resultados desses estudos. Enfatizaram que o poder de teste pode ser aumentado utilizando número de amostras maiores ou, alternativamente, ampliando o "efeito tamanho", e também um interesse em 
diferenças maiores entre os escore médios, ou minimizando a variabilidade dos dados. Concluíram que, em estudos em que as amostras são pequenas e os resultados oscilam bastante, deve-se optar por testes não paramétricos, como o Kruskal-Wallis.

WU; WESSELINK ${ }^{147}$, também em 1993, realizaram, por meio de levantamento bibliográfico, uma análise crítica dos métodos de infiltração. Averiguaram que o método mais empregado foi a medição linear da infiltração de marcadores (corantes ou radioisótopos). Observaram que ocorreu um alto nível de variações entre estudos empregando métodos similares. Discutiram os problemas de tais estudos e concluíram que mais pesquisas deveriam ser realizadas sobre as metodologias de infiltração, ao invés de continuar avaliando a capacidade seladora de diferentes materiais e técnicas que podem fornecer poucas informações relevantes.

WU et al. ${ }^{151}$, no mesmo ano, desenvolveram um método onde o transporte propagativo de água da porção coronária para apical foi determinado pelo movimento de bolhas de ar no tubo de vidro capilar, conectado no ápice de secções radiculares experimentais. Utilizaram, para tal feito, uma pressão de $120 \mathrm{Kpa}(1,2 \mathrm{~atm})$. Prepararam os canais radiculares de 60 caninos humanos superiores que, posteriormente, foram obturados com guta-percha e cimento pela técnica da condensação lateral ativa. Trinta dessas raízes foram expostas a penetração bacteriana de Pseudomonas aeruginosas, colocadas no reservatório coronário. Ao final de 50 dias todos os espécimes permitiram a penetração do microrganismo até a porção apical. Todos os espécimes foram, posteriormente, submetidos ao transporte de água. Os resultados foram divididos em três categorias, onde 39 raízes estavam na categoria impermeável, 14 na de leve infiltração e 7 na de acentuada infiltração. Dois espécimes mostraram penetração bacteriana dentro da categoria leve e acentuada. O teste com penetração prévia de bactéria não influenciou significantemente no padrão de transporte de fluidos, que foi medido subseqüentemente. Concluíram que o transporte de fluido através de canais obturados, na maioria das raízes não permite a passagem de bactérias. 
BARTHEL et al. ${ }^{14}$ avaliaram, em 1994, a infiltração apical do cimento AH26 espatulado em diferentes consistências, em função da variação da proporção pó/resina e da temperatura. Empregaram 60 incisivos superiores que foram instrumentados e divididos em 4 grupos. Os dentes foram obturados pela técnica da condensação lateral e cone único, utilizando AH26 na proporção ideal $(2 / 1)$ e fluida $(0,8 / 1)$, aquecido e em temperatura ambiente. Imergiram os dentes em fucsina básica e, posteriormente, seccionaram os dentes e avaliaram o grau da infiltração, microscopicamente. Verificaram que o melhor selamento foi conseguido com o AH26 fluido em temperatura ambiente empregando a condensação lateral.

MEDEIROS; PESCE; MOURA ${ }^{96}$, no mesmo, ano averiguaram o selamento apical proporcionado por duas diferentes condições de inserção do cimento obturador. Empregaram 30 incisivos superiores que foram abertos e instrumentados, delimitando como limite apical $1 \mathrm{~mm}$ do forame. Posteriormente, obturaram os dentes pela técnica da condensação lateral passiva utilizando o cimento N-Rickert, porém, variando-se o método de inserção do cimento, obedecendo a seguinte ordem: G 1 - Inserção do cimento com a ponta do cone de guta-percha em movimentos de vai e vem até que todo o cone estivesse envolvido. G 2 - Inserção de uma única vez do cone de guta-percha besuntado com o cimento; Inserção do cone sem cimento. Posteriormente, impermeabilizaram a superfície externa do dente com exceção da porção apical e imergiram em solução de azul de metileno a $0.5 \%$ a $37^{\circ} \mathrm{C}$, por 72 horas. Posteriormente, incluíram os dentes em gesso e desgastaram até que toda obturação fosse visualizada e, então, mediram a infiltração. Os resultados mostraram que o $G 1$ apresentou melhor selamento seguido do $G 2$, e se diferenciaram significantemente do $G 3$.

SMITH; STEIMAN ${ }^{129}$, também em 1994, compararam in vitro a microinfiltração apical de quatro cimentos obturadores de canais radiculares, utilizando o método de infiltração de corante e clarificação da estrutura dentinária para visualização do corante infiltrado. Ketac-Endo, Tubliseal (fórmula velha), Tubliseal (nova fórmula) e o cimento de Roth 801 foram comparados com um 
grupo controle em que a condensação lateral da guta-percha foi realizada sem cimento. Dentes anteriores foram instrumentados, obturados de acordo com o grupo e estocados por 4 dias. Decorrido esse período, os dentes foram impermeabilizados e imersos em corante de tinta da Índia por 8 dias. Posteriormente à imersão no corante, os dentes foram desmineralizados, clareados e, então, se determinou a penetração linear do corante. Observaram que todos os grupos com cimento selaram significantemente mais que o grupo sem cimento. Não houve diferença significante entre as fórmulas do Tubliseal, e o Ketac-Endo apresentou significativamente mais infiltração que os outros cimentos.

WU; DE GEE; WESSELINK ${ }^{148}$, também em 1994, compararam o método de penetração de corante com o modelo de transporte de fluido em obturações endodônticas. Sessenta secções radiculares de incisivos centrais superiores humanos foram obturadas por uma técnica modificada de maneira a permitir uma leve quantidade de infiltração e, então, dividiram os dentes dentro de três grupos iguais. Vinte secções radiculares foram inicialmente montadas em um modelo de transporte de fluido e permitiram a passagem desse fluido sobre uma pressão de $10 \mathrm{Kpa}(0,1 \mathrm{~atm})$. Outras vinte secções radiculares foram montadas de acordo com o mesmo método, porém, antes foram sujeitadas ao transporte de ar sob a mesma pressão. As vinte secções remanescente não foram expostas ao transporte de fluido e nem de ar. Então, todas as 60 secções radiculares foram sujeitadas a penetração de uma solução de azul de metileno a $2 \%$. Verificaram, pelos resultados, que o transporte de fluidos foi um método muito mais sensível em detectar espaços ao longo da obturação do que o corante. Depois do transporte do fluido por três horas sob baixa pressão para eliminar o ar, o corante penetrou significantemente mais profundamente do que sem o transporte de fluido prévio, o qual sugeriu que o ar presente em espaços vazios ao longo da obturação do canal preveniu a penetração do corante.

WU; DEGEE; WESSELINK ${ }^{149}$, no mesmo ano, avaliaram a capacidade seladora dos cimentos AH26, Sealapex, Ketac-endo e Tubli-seal, apresentando diferentes espessuras. Empregaram para essa análise dentes bovinos que foram seccionados e preparados, obtendo-se espécimes com $4 \mathrm{~mm}$ de altura e $7 \mathrm{~mm}$ de 
diâmetro externo e $3 \mathrm{~mm}$ em diâmetro interno (luz do canal). Obturaram as espécimes com os cimentos em estudo e guta-perchas preparadas em dois diâmetros, de $3 \mathrm{~mm}$ e $2,5 \mathrm{~mm}$, e um grupo de dentes foi apenas preenchido com os cimentos. Com isso obteve-se amostras obturadas com espessura de cimento de $0,25 \mathrm{~mm}, 0,05 \mathrm{~mm}$ e $3 \mathrm{~mm}$. Para averiguação da capacidade seladora, os espécimes foram montados em um aparato de transporte de fluido, onde a infiltração foi determinada em microlitro, Os resultados mostraram que na espessura de 3mm o AH26 e o Sealapex apresentaram os melhores resultados. $\mathrm{Na}$ espessura de $0,25 \mathrm{~mm}$, o $\mathrm{AH} 26$, Sealapex e Ketac-endo selaram melhor que o Tubli-seal e na espessura de $0,05 \mathrm{~mm}$ o Ketac-endo se portou melhor que os demais cimentos. Verificaram, também, que a espessura de cimento influência significantemente na capacidade seladora.

AHLBERG; ASSAVANOP; TAY², em 1995, compararam o padrão de infiltração apical mostrado pelo azul de metileno a 5\% e tinta da Índia. Utilizaram 125 dentes unirradiculados que foram instrumentados pela técnica escalonada regressiva. Dividiram os dentes em três grupos que foram obturados pela técnica da condensação lateral e os seguintes cimentos: Sealapex(40 raízes);Tubli-seal (40 raízes); Ketac endo (20 raízes). As demais raízes foram utilizadas como controles positivos e negativos. A raízes foram seladas e imersas por 7 dias em azul de metileno ou tinta da Índia. Seccionaram longitudinalmente após o período e avaliaram a penetração do corante em esteriomicroscópio. Averiguaram que, em todos os grupos, o azul de metileno infiltrou mais do que a tinta da Índia, sendo a diferença significante para os grupos com cimento.

BONETTI FILHO et al. ${ }^{22}$, no mesmo ano, avaliaram o selamento apical proporcionado pelos cimentos Sealer 26 e Ketac-endo, comparando-os ao cimento Fillcanal. Empregaram 39 incisivos superiores que foram instrumentados transpassando o forame em $1 \mathrm{~mm}$ até a lima $\mathrm{K} 50$. Cones 50 foram testados e transpassados além ápice, cortando-se o excesso com lâmina de bisturi. Posteriormente, realizaram a obturação pela técnica da condensação lateral, variando-se os cimentos. Impermeabilizaram os dentes e imergiram em solução de azul de metileno a $2 \%$ a uma temperatura de $37^{\circ} \mathrm{C}$ por 24 horas. Na seqüência, 
os dentes foram lavados, raspados e seccionados para mensuração da infiltração, que foi realizada com o aparelho "Profile projector" com aumento de 20X. Verificaram que o Sealer 26 apresentou melhor selamento, seguido do Fillcanal e os piores resultados foram com o Ketac-endo, apresentando diferença estatística nas comparações globais.

CARVALHO et al. ${ }^{27}$ avaliaram, em 1995, o uso da vibração ultra-sônica no selamento apical proporcionado por cimentos obturadores àbase de óxido de zinco e eugenol, sendo eles o Fillcanal, cimento de Grossman - USP, Endo-fill. Utilizaram trinta dentes unirradiculados que foram instrumentados e obturados pela técnica de vibração ultra-sônica, variando os cimentos. Concluída a obturação os dentes foram imersos em azul de metileno a $0.5 \%$ e mantidos a $37^{\circ} \mathrm{C}$ por 48 horas. Findado o período, lavaram os dentes e seccionaram no sentido proximal para mensuração da infiltração. Os resultados mostraram que o Fillcanal apresentou a menor infiltração.

HOLLAND, MURATA; SALIBA ${ }^{61}$, também em 1995, verificaram o efeito a curto e médio prazo de resíduos de hidróxido de cálcio no selamento marginal após obturações com diferentes materiais. Empregaram dentes humanos unirradiculados que foram preparados biomecanicamente recebendo ou não, a seguir, um curativo de demora com hidróxido de cálcio. Posteriormente, obturaram os dentes pela técnica da condensação lateral e os cimentos: Fillcanal, AH26, Apexit. Após 24 horas e 30 dias imergiram os dentes em azul de metileno a 2\% em ambiente com vácuo. Na seqüência, seccionaram os dentes e dimensionaram a infiltração. Verificaram que o curativo de hidróxido de cálcio determina melhor selamento e esse efeito é mantido a médio prazo. Com relação aos cimentos o Apexit foi que selou melhor, seguido do AH26.

SAUNDERS; SAUNDERS ${ }^{118}$, no mesmo ano de 1995, avaliaram a infiltração coronária proporcionada por duas técnicas de obturação e dois cimentos de hidróxido de cálcio após a estocagem por longo período de tempo. Utilizaram 90 dentes unirradiculados que foram preparados biomecanicamente e, então, divididos em quatro grupos de 20 dentes cada, em função da técnica de obturação e cimento utilizado. Dois grupos foram obturados pela técnica da 
condensação lateral, sendo que em um deles o cimento empregado foi o Sealapex e no outro o Apexit. Nos outros dois grupos a técnica de obturação utilizada foi a JS Quickfill, uma técnica termoplastificadora, variando também o cimento. Os dez dentes remanescente serviram como controle positivo e negativo. Após as obturações, seccionaram as coroas dos dentes e, então, os estocaram por 1 ano a $37^{\circ} \mathrm{C}$ em solução salina. Findado este período, imergiram os dentes em tinta da India utilizando pressão reduzida e, então, clarearam os dentes para a determinação da magnitude de infiltração em microscópico com aumento de 6 vezes. Os resultados mostraram que a técnica da condensação lateral selou significantemente mais do que a JS Quickifill. Não houve diferença entre os dois cimentos na técnica da condensação lateral, porém na termoplastificada 0 Sealapex infiltrou significantemente mais do que o Apexit.

BRAMANTE; DUARTE; BRAMANTE ${ }^{25}$, no ano de 1996, averiguaram o selamento apical proporcionado pelos cimentos com hidróxido de cálcio Apexit, Prócanal e Set sealer, comparando ao óxido de zinco e eugenol. Empregaram quarenta dentes unirradiculados que tiveram seus forames padronizados até a lima $\mathrm{K} 30$, transpassando $1 \mathrm{~mm}$ além do comprimento real do dente. Instrumentaram o canal pela técnica escalonada regressiva determinando, a lima K 50 como instrumento de memória e, então, impermeabilizaram as superfícies externas e obturaram o canal pela técnica do cone único, variando os cimentos empregados. Concluída a obturação, selaram as coroas e imergiram os dentes em solução de azul de metileno a $2 \%$ em uma temperatura de $37^{\circ} \mathrm{C}$, por 7 dias. Ao fim do período estipulado, lavaram os dentes, e seccionaram-nos e analisaram a magnitude de infiltração. Os resultados mostraram que o Apexit apresentou os melhores resultados, seguido do Pró-canal. Os piores resultados foram com o Set sealer.

HOLLAND et al. ${ }^{65}$, também no ano de 1996, avaliaram o selamento proporcionado por quatro cimentos endodônticos àbase de hidróxido de cálcio, comparando os resultados àueles obtidos pelo óxido de zinco e eugenol. Utilizaram 50 dentes unirradiculados que foram instrumentados e obturados pela técnica da condensação lateral, variando os cimentos, utilizando os seguintes: 
Sealapex, CRCS, Sealer 26, Apexit e óxido de zinco e eugenol (grupo controle). Após a obturação imergiram os dentes em água por 24 horas e, posteriormente, em vácuo por dez minutos para, então, estocarem os espécimes em corante de azul de metileno por 12 horas. Concluído esse período seccionaram os dentes e analisaram a infiltração com o auxílio de estereomicroscópio munido de ocular micrometrada. Os resultados mostraram que os cimentos com hidróxido de cálcio selaram mais que o óxido zinco e eugenol. Os resultados obtidos com CRCS foram significantemente piores do que aqueles com Sealapex, Apexit e Sealer 26.

SEM; PISKIN; BARAN ${ }^{122}$, no mesmo ano estudaram, in vitro a possível correlação entre a penetração de quatro cimentos no interior de túbulos dentinários com a capacidade de selar o canal radicular. Empregaram na realização do estudo 45 dentes que foram instrumentados, removendo-se a smear layer, obturou-se os canais pela técnica do cone único com guta-percha e um dos quatro cimentos seguintes Diaket, Endomethasone, CRCS ou Ketac-endo. A extensão da infiltração foi medida por meio de escores após a imersão dos dentes em tinta da Índia por 72 horas. Os mesmos espécimes foram usados para averiguar a penetração do cimento no interior dos túbulos dentinários através do método de microscopia eletrônica de varredura. Verificaram que o Diaket tinha a menor infiltração com relação aos outros cimentos. No que diz respeito à penetração no interior dos túbulos o mesmo Diaket demonstrou uma imbricação mais homogênea enquanto que o Ketac-endo mostrou os piores resultados, ou seja, maior infiltração marginal e menor penetração no interior dos túbulos. Verificaram que houve uma relação inversa entre penetração tubular e infiltração do corante, apesar dessa correlação não ser estatisticamente significante.

PANTHOMVANICH; EDMUNDS ${ }^{107}$, também em 1996, investigaram in vitro a extensão de infiltração apical em canais simulados em blocos de resina, utilizando quatro métodos de infiltração diferentes, sendo eles: penetração passiva do corante; centrifugação; vácuo seguido da penetração passiva, pressão aumentada seguida da penetração passiva. Empregaram quarenta blocos de resina, que foram preparados e obturados e, posteriormente, divididos em quatro grupos de 10 blocos cada em função do método utilizado para a penetração do 
corante azul de metileno a $2 \%$. Após a imersão, registraram a maior penetração do corante nas quatro faces de cada bloco. Verificaram que houve uma larga variação na infiltração em cada espécime individual e entre os espécimes dentro de cada grupo. Observaram que a penetração passiva apenas infiltrou significantemente menos que as outras três técnicas.

TANOMARU FILHO et al. ${ }^{138}$ em 1996, compararam a capacidade seladora apical de dois cimentos obturadores com hidróxido de cálcio, sendo eles o Sealapex e o Sealer 26, \&̀uela promovida pelo cimento de óxido de zinco e eugenol. Empregaram trinta dentes unirradiculados que foram abertos e tiveram seus forames padronizados até a lima $\mathrm{K} 30$ passando $1 \mathrm{~mm}$ além do comprimento do dente. Posteriormente, instrumentaram os canais pela técnica escalonada regressiva determinando como instrumento de memória a lima K50. Os dentes foram impermeabilizados e, então, obturados pela técnica do cone único, variando-se os cimentos. Após a obturação, as coroas foram seladas e imergiram os dentes em solução de azul de metileno a $2 \%$ em uma temperatura de $37^{\circ} \mathrm{C}$ por 7 dias. Após o período determinado, lavaram os dentes e seccionaram no sentido vestíbulo lingual e averiguaram a magnitude da infiltração. Os resultados mostraram que o Sealer 26 apresentou melhor selamento, diferenciando-se estatisticamente dos demais.

ALMEIDA $^{8}$, em 1997, em sua tese de doutorado avaliou o cimento $\mathrm{AH}$ Plus quanto ao selamento apical, comparando-o ao Ketac-endo e ao Fill canal. Utilizou 99 incisivos centrais superiores humanos extraídos, que foram divididos em três grupos de 33 dentes cada, que foram inicialmente instrumentados com limas Nitiflex até o número 55, ultrapassando-se $2 \mathrm{~mm}$ do forame apical. Posteriormente, realizou a obturação dos dentes com guta-percha e os cimentos em estudo, utilizando a técnica clássica condensação lateral. Efetuada as obturações realizou a impermeabilização dos dentes com esmalte de unha em toda a sua extensão, exceto um a dois $\mathrm{mm}$ ao redor do forame apical. Então, imergiu os dentes em corante de azul de metileno a $2 \%$ sob vácuo por 24 horas e, posteriormente, realizou a lavagem do mesmo por mais 24 horas e, então, seccionou-os longitudinalmente. Determinou a penetração do corante com o 
auxílio de um perfilômetro e os dados foram submetidos a análise estatística. Verificou que o $\mathrm{AH}$ Plus apresentou os menores índices de infiltração, diferenciando-se estatisticamente do Fill canal e Ketac-endo. Entre os dois últimos não houve diferença estatística.

ANTONIO; MOURA ${ }^{11}$, também em 1997, avaliaram in vitro a capacidade seladora proporcionada pelos cimentos N-Rickert, AH26, Sealapex e Ketac-endo. Utilizaram 95 dentes unirradiculados que tiveram seus forames padronizados até a lima tipo $\mathrm{K} 30$ ultrapassando $2 \mathrm{~mm}$ além do comprimento do dente. Posteriormente, impermeabilizaram os dentes e, então, realizaram a obturação pela técnica da condensação lateral passiva, variando o cimento e em um grupo utilizou-se apenas guta-percha. Imergiram os dentes em azul de metileno a $2 \%$ por 72 horas. Concluído esse período, seccionaram-nos e submeteram-nos àmedição da infiltração utilizando um método computadorizado. Os resultados mostraram que, na comparação global, não houve diferença significante entre os cimentos porém, na comparação dois a dois, o Ketac-endo apresentou os piores resultados diferenciando-se estatisticamente dos demais.

KONTAKIOTIS; WU; WESSELINK ${ }^{79}$, no mesmo ano, averiguaram o efeito do curativo de hidróxido de cálcio no selamento apical de obturações endodônticas. Empregaram 80 raízes de incisivos centrais superiores que foram divididas em dois grupos, sendo que no grupo I 40 raízes receberam o curativo e no grupo II, as outras 40 raízes não receberam. Todas as raízes tiveram os canais obturados com guta-percha e cimento Tubli-seal. Mediram a infiltração de 20 raízes em cada grupo por modelo de transporte de fluido modificado, realizando as medidas nos períodos de $48 \mathrm{~h}, 2,4,8,16$ semanas. No entanto, nas outras 20 raízes de cada grupo a infiltração foi medida empregando o corante de azul de metileno a $1 \%$. Os resultados mostraram que, usando o modelo de transporte de fluido, nenhuma diferença significante foi encontrada entre os grupos estudados. No método com azul de metileno, o grupo com curativo, infiltrou significante menos que o grupo em que o curativo não foi empregado. Os resultados controversos entre os modelos indicam que problemas existem com os mesmos. 
ZMENER et al. ${ }^{155}$, também em 1997, examinaram a capacidade seladora de um novo cimento endodôntico de resina epóxica, o AH Plus, utilizando - AH26 como controle e parâmetro de comparação. Prepararam biomecanicamente o canal radicular de 72 dentes unirradiculados, empregando a técnica escalonada regressiva. Posteriormente, obturaram os dentes pela técnica da condensação lateral, com um dos dois cimentos, e então, estocaram os espéciemes por 48 horas a $37^{\circ} \mathrm{C}$ em $100 \%$ de umidade para permitir a presa dos cimentos. Finalizado este período, imergiram os dentes em azul de metileno a 5\% por 2, 4, 10 dias. No final de cada período, removeram os dentes do corante e seccionaram longitudinalmente e determinaram a infiltração em um estereomicroscópio. Os resultados mostraram que o AH26 selou, estatisticamente, melhor que o $\mathrm{AH}$ Plus nos três períodos analisados. Houve também, diferença estatística entre os períodos de imersão ocorrendo um aumento da infiltração com o passar do tempo.

ANTONOPOULUS; ATTIN; HELLWIG ${ }^{12}$, em 1998, estudaram métodos de penetração do corante em condições normais, sob pressão negativa ou sob alta pressão. Utilizaram noventa incisivos superiores humanos que foram instrumentados e obturados ou pela técnica da condensação lateral ativa, ou pela técnica do cone único, usando em ambas as técnicas o AH Plus como cimento obturador. Após a obturação os dentes foram mantidos em ambiente a $37^{\circ} \mathrm{C}$ e $100 \%$ de umidade por 7 dias para presa do cimento. Concluido esse período imergiram os dentes no corante que foi a tinta da Índia para penetração passiva e pressão negativa (60 Torr) e a Rhodamina B com resina epóxica para condições de alta pressão (200 Mpa). Avaliaram a infiltração através da clareação dos espécimes, medindo linearmente a face que infiltrou mais e todas as quatro superfícies. Os resultados revelaram nenhuma diferença significante entre a penetração passiva e pressão negativa do corante. A infiltração pelo método de alta pressão foi significantemente mais baixa. Com relação àécnica de obturação, a capacidade seladora, foi similar entre elas. Concluíram que não há necessidade de usar pressão negativa para avaliar a capacidade seladora de obturação in vitro. 
OLIVER; ABBOT ${ }^{102}$, em 1998, compararam in vitro a infiltração apical e coronária permitida pelo Ketac-endo e AH26, quando utilizada a técnica da condensação lateral ativa. Utilizaram 28 incisivos superiores que tiveram suas coroas removidas e, posteriormente, os canais foram preparados biomecanicamente. Dividiram as raízes em dois grupos experimentais de doze espécimes cujos canais foram obturados com guta-percha e os cimentos em estudo pela técnica da condensação lateral ativa. No grupo do Ketac-endo, após a obturação, foram removidos $3 \mathrm{~mm}$ de guta-percha e cimento da porção coronária e esse espaço foi preenchido apenas pelo Ketac-endo. Os outros quatro dentes serviram de controle positivo e negativo. Concluída a etapa de obturação e presa dos cimentos, impermeabilizaram os dentes e imergiram em solução de azul de metileno a $2 \%$ em ambiente com vácuo de $660 \mathrm{~mm}$ de mercúrio por 5 minutos e, então, após esse pequeno período, deixaram no corante por mais 2 dias. Finalizado esse tempo, seccionaram os dentes e determinaram a magnitude de infiltração. Verificaram os seguintes resultados na porção apical: Ketac-endo 1,08 mm; AH26 0,75 mm; e na porção coronária: Ketac-endo 6,29 mm; e AH26 6,67 $\mathrm{mm}$. Observaram que esses dados não foram estatisticamente significantes no confronto entre materiais porém, intra materiais, a infiltração apical foi significantemente menor que a cervical.

WU; KONTAKIOTIS; WESSELINK ${ }^{150}$, no mesmo ano, analisaram a perda de cor do azul de metileno quando em contato com seis materiais odontológicos, sendo eles o amálgama, Fuji II, pasta de hidróxido de cálcio, MTA, óxido de zinco e eugenol, e o Cavit. Utilizaram tubos de silicone e raízes humanas com $10 \mathrm{~mm}$ de comprimento e 1,5 mm de diâmetro interno que foram preenchidos com os materiais testados e posteriormente imersos em $0,8 \mathrm{~mL}$ de solução de azul de metileno a $1 \%$. Determinaram a densidade ótica do corante antes e depois de 24, 48 e 72 horas de imersão, utilizando para isso um espectrofotôómetro com 596 $\mathrm{nm}$ de comprimento de onda. Verificaram que todos os materiais com exceção do Fuji II levaram a descoloração do azul de metileno, sendo que após 24 horas a densidade ótica do corante no grupo do hidróxido de cálcio já havia reduzida em $73 \%$, enquanto que para o MTA a redução era de $84 \%$. Concluíram que o azul de 
metileno é descolorido por alguns materiais odontológicos, o que pode levar a resultados incorretos no teste de infiltração com esse corante, e concluíram também que na realização de testes com outros corantes, a densidade ótica deveria ser medida antes do emprego do mesmo para averiguar se não sofre alteração pelos materiais.

ECONOMIDES et al. ${ }^{35}$, em 1999, examinaram o efeito da Smear Layer na microinfiltração apical após 16 semanas. Utilizaram cento e quatro dentes humanos extraídos, que foram divididos em quatro grupos: A1: com Smear Layer e obturação com guta-percha + cimento de Roth 811; A2: com Smear Layer e obturação com guta-percha + AH 26; B1: sem Smear Layer e obturação com gutapercha + cimento de Roth 811; B2: sem Smear Layer e obturação com gutapercha $+\mathrm{AH}$ 26. A microinfiltração foi determinada pelo método eletroquímico. Paralelamente, 12 dentes foram examinados em microscopia de varredura para comprovar a eficiência do método em remover a Smear Layer. Os resultados mostraram que a remoção da Smear Layer reduziu significantemente a infiltração do AH 26. Quanto ao Roth 811, a Smear Layer não interferiu no selamento.

GALE; DARVELL ${ }^{49}$, também no ano de 1999, revisaram a evidência de permeabilidade dentinária, procurando esclarecer e enfatizar o efeito da permeabilidade nos testes de infiltração e chamaram a atenção para a necessidade de uso de métodos especiais para evitar tal efeito. Realizaram uma revisão sobre o assunto que abrangeu entre 1887 a 1997, sendo avaliados 249 artigos. Concluíram que o pré-requisito para alguns testes de penetração de corantes é que o espécime não fraturado são por si só é impermeável aos marcadores. Entrada do corante não pode ser usada para indicar corretamente a localização e severidade da trinca. A relativa impermeabilidade do esmalte intacto, permite os testes de selamento na interface esmalte-restauração, porém o mesmo não é verdadeiro quando se usa a dentina a qual é porosa. A maioria dos marcadores atravessa seus túbulos e, portanto, resultados falsos positivos são muito comuns. Recente interesse em agentes de união dentinária tem aumentado a necessidade desses testes com a dentina, mas esses sérios fatores de confusão têm permanecidos despojados e tem sido somente controlado, adequadamente, 
em apenas um dos estudos levantados. Se os testes de infiltração de corantes são feitos para serem confiáveis, então adequado controle é requerido.

SIQUEIRA JÚNIOR et al. ${ }^{128}$ também no ano de 1999 avaliaram in vitro a infiltração coronária de saliva no interior de canais radiculares obturados pela técnica da condensação lateral de guta-percha, utilizando dois cimentos contendo hidróxido de cálcio. Os canais obturados com guta-percha e Sealapex ou Sealer 26 foram montados em um aparato e expostos àsali va. Verificaram o número total de dias requerido para completa contaminação dos canais radiculares. A avaliação foi conduzida por 60 dias. Observaram que 35\% dos espécimes do Sealer 26 apresentaram total contaminação após 60 dias, enquanto que no grupo de Sealapex esse valor foi de $80 \%$ decorrido o mesmo período. Concluíram que o Sealer 26 demonstrou menos infiltração coronária de saliva que o Sealapex.

\section{3 - Da análise de outras propriedades físico-químicas}

GROSSMAN ${ }^{55}$, em 1958, estipulou uma fórmula de cimento obturador (cimento de Grossman), bem com as propriedades ideais que deve possuir um cimento obturador, sendo elas: 1 - selamento hermético; 2 - constância volumétrica; 3 - aderência à paredes do canal; 4 - ser tolerável pelos tecidos apicais e periapicais; 5 - boa qualidade de trabalho; 6 - fácil introdução no canal; 7 - bom tempo de trabalho; 8 - tomar presa no interior do canal; 9 - não alterar a cor do dente; 10 - possuir ação bactericida ou bacteriostática. O autor também realizou testes clínicos com o cimento proposto e encontrou bons resultados.

HIGGINBOTHAM $^{59}$, no ano de 1967, realizou testes que averiguaram o tempo de presa, espessura de película, solubilidade, radiopacidade e capacidade seladora de alguns cimentos endodônticos. Os materiais avaliados pelo autor foram: Kerr pulp canal sealer puro e com associação de acetato de zinco, Tubliseal; Diaket A; Proco-sol; Kloropercha. Empregou a especificação № 8 proposta pela ADA utilizada para avaliação do fosfato de zinco, para averiguação do tempo de presa e espessura de película. Para constatação das outras propriedades, se seguiu metodologia proposta por outros autores, sendo que no teste de infiltração 
empregou o radioisótopo $\mathrm{Ca}^{45}$ como marcador. Pelos resultados o autor verificou para o tempo de presa que os materiais Kerr pulp canal sealer, Tubli-seal e Diaket A, apresentaram uniformidade. A adição de acetato de zinco acelerou drasticamente o tempo de presa do Kerr pulp canal sealer. $\mathrm{Na}$ espessura de película, o Tubli-seal demonstrou a menor. Quanto àsolubilidade, o Proco -sol foi o menos solúvel tanto em água quanto no ácido cítrico. No que diz respeito à radiopacidade, os melhores resultados foram alcançados pelo Kerr pulp canal sealer puro e com acetato de zinco. Para a capacidade seladora, o Proco-sol e o Kerr pulp canal sealer selaram melhor após um mês do que em um dia, e o autor concluíu que cuidadosa técnica de condensação se faz necessária para alcançar melhor capacidade seladora.

CURSON; KIRK ${ }^{30}$, em 1968, compararam dez cimentos obturadores de canais quanto a qualidade seladora, agressão tecidual, adesão e tempo de presa. Verificaram que para o tempo de presa, o cimento de fosfato de zinco, o cimento de óxido de zinco e eugenol (presa rápida e o reforçado) e o Tubli-seal a presa foi rápida sendo que a umidade acelerou o tempo de presa com exceção do fosfato de zinco. No teste de infiltração, averiguaram que os cimentos de óxido de zinco eugenol e os resinosos, entre eles o $\mathrm{AH} 26$, foram os mais satisfatórios. $\mathrm{Na}$ adesividade verificaram que o óxido de zinco eugenol foi o que manteve maior adesividade, se portando melhor. Quanto àagressão tecidual, todos os cimentos agrediram, porém, a reação foi severa para o fosfato de zinco e bioxol. Concluíram que todos os cimentos de óxido de zinco e eugenol e o de resina epóxica AH26 são favoráveis como cimentos obturadores de canais e que o óxido de zinco eugenol não modificado é um cimento muito satisfatório.

WEISMAN $^{145}$, em 1970, avaliou o escoamento (fluidez) de dez cimentos obturadores de canais radiculares, sendo eles: AH26, Diaket, cimentos de Grossman n: 811, cimento de Grossman n: 812, Kerr pulp canal sealer, Klorapercha N²0; Proco-sol, Tubli-seal, Pulp dent "ZOC". Utilizou um método que consistia de uma pipeta com tamanho de 33,6 mm de altura, 0,19 mm de diâmetro e volume de $0,001 \mathrm{~mL}$, que era conectada a um $\mathrm{T}$ com uma borracha na extremidade vertical e na horizontal de um lado foi aplicado vácuo e do outro o 
dedo. Realizou a espatulação dos cimentos e então levou o conjunto pipeta e T sobre o cimento e aplicou o vácuo por 15 segundos. Após esse período mediu o quanto de cimento entrou na pipeta. Os resultados mostraram que o Pulp dente apresentou a maior fluidez, seguido da mistura "ZOC" e do Tubli-seal. Os piores resultados ocorreram com o Proco-sol e Diaket.

BOVIS; HARRINGTON; WILSON ${ }^{24}$, em 1971, descreveram um aparelho para determinação do tempo de trabalho e tempo de presa de materiais empregados em odontologia, denominado de reômetro oscilante. Apresentaram a foto e o esquema do aparelho, bem como relataram o funcionamento do mesmo e realizaram a determinação do tempo de trabalho e de presa de algumas resinas compostas quimicamente ativadas. Concluíram que a simplicidade, praticidade e velocidade de operação do reômetro oscilante, o torna praticável para os testes padrões. Quanto ̀̀ resinas compostas avaliadas, a Adaptic e a Concise mostraram os melhores resultados.

WIENER; SCHILDER ${ }^{146}$, em 1972 testaram, o tempo de presa dos cimentos Kerr pulp canal sealer, Tubli-seal, Proco-sol, Proco-sol radiopaco com prata e os cimentos da Roth n: 501, 511, 601 e 801. Avaliaram os cimentos sob as seguintes condições ambientais: Temperatura: $62^{\circ} \mathrm{F}, 72^{\circ} \mathrm{F}, 82^{\circ} \mathrm{C}$ e umidade relativa de $0 \%, 50 \%$ e $100 \%$. Espatularam os cimentos sob condições controladas de proporção pó-líquido e inseriram em cubos 14,5 por 14,5, por 14,5 e levaram 0 conjunto nas condições ambientais a serem avaliadas. Uma espátula contendo 46 gramas foi utilizada para constatação da presa. Observaram que o Tubli-seal apresentou o tempo de presa mais rápido em todas as condições. Notaram também, que o aumento da temperatura e da umidade aceleraram o tempo de presa em todos os materiais analisados.

ABRAMOVICH; GOLDBERG ${ }^{1}$ verificaram, em 1976, por meio de microscopia eletrônica de varredura, a adesividade æ̀ paredes de canais radiculares dos cimentos AH26, Diaket A, Tubli-seal, cimento de Grossman e das pastas de hidóxido de cálcio e o Biocalex. Dentes unirradiculados tiveram os canais dilatados até a lima K 50 e, posteriormente, obturados com os cimentos pela técnica do cone único de guta-percha. Os dentes foram, então, mantidos a 
$37^{\circ} \mathrm{C}$ por cinco dias para a presa dos materiais. Para as pastas, os dentes foram dilatados nos dois terços coronários e, então, preenchidos com as mesmas. Em cada dente foram feitos três trocas das pastas, com intervalos de 7 e 15 dias. Concluídos os períodos, os dentes foram seccionados longitudinalmente e avaliados em microscopia eletrônica de varredura. Da análise dos resultados, os autores concluíram que nenhum dos materiais usados nesse estudo mostraram total obliteração dos túbulos dentinários. A dificuldade de obliterar os túbulos indicam que os cimentos não aderem, porém são meramente comprimidos ̀̀ paredes.

GROSSMAN ${ }^{56}$, no mesmo ano, testou o tamanho das partículas, fluidez, tempo de presa, adesão e infiltração marginal dos cimentos AH26, Diaket A, Kerr sealer, Mynol, N2, N2 sem chumbo, Proco-sol, Roth 801, Roth 811, RC 2B, Tubli-seal e óxido de zinco eugenol. Utilizando metodologias adaptadas, avaliou as propriedades físicas citadas acima. Verificou que para o tamanho das partículas, o AH26, Roth 811, Kerr sealer e Roth 801 demonstraram os melhores resultados, enquanto que o Diaket A e Proco-sol foram os piores. Quanto àluidez, esta foi maior para o AH26, seguido do Roth 801, Mynol e Roth 811, já o RC 2B, N2, N2 sem chumbo e óxido de zinco eugenol não fluíram. No tempo de presa, observou-se que o Proco-sol seguido do AH26 tiveram os maiores tempos, sendo eles: 40 horas e 32 horas, respectivamente, enquanto que o Kerr sealer e o Tubliseal apresentaram os menores tempos, sendo de uma hora para menos. $\mathrm{Na}$ adesão dos cimentos, o AH26 e o Diaket A foram os mais adesivos, enquanto que o óxido de zinco eugenol não apresentou adesividade. Para a infiltração marginal, o Diaket demonstrou melhor comportamento, tanto após a espatulação quanto após a presa, enquanto que o óxido de zinco eugenol e o Mynol foram os piores.

McCOMB; SMITH ${ }^{89}$, também em 1976, testaram algumas propriedades físicas de nove cimentos endodônticos encontrados comercialmente e dois materiais experimentais, a base de policarboxicilato. Avaliaram a fluidez, tempo de presa, radiopacidade, força compressiva, adesão à dentina e solubilidade. Averiguaram, pelos resultados, que os cimentos a base de óxido de zinco e eugenol apresentaram baixa resistência a força tênsil e alta solubilidade, 
conjuntamente com o Diaket $\mathrm{A}$ e não mostraram nenhuma adesão àdentina. $\mathrm{O}$ AH26 proporcionou bons resultados quanto àresistência, fluidez, radiopacidade e adesão àdentina, porém a solubilid ade foi alta apra um material epóxico. Os dois mateirais experimentais apresentaram significantemente melhores resultados do que os cimentos comercializados quanto àresistência, adesão e solubilidade, sendo esta última bem baixa. Para a adesão àdentina os resultados dos experimentais foi duas vezes maior que a averiguada para o $\mathrm{AH} 26$. Verificaram que a grande variação nas propriedades dos materiais encontrados no mercado, demonstraram a natureza empírica desses cimentos.

BENATTI; STOLF; RUHNKE ${ }^{17}$, em 1978, estudaram a consistência, tempo de presa e alteração dimensional de cinco materiais obturadores, sendo eles: Fill canal, Endomethasone, Trimcanal, Alpha canal e óxido de zinco eugenol. A metodologia utilizada na consistência foi uma adaptação da norma $n=8$ do grupo brasileiro de especificação para materiais dentários. Para averiguação do tempo de presa empregaram um penetrômetro, seguindo a recomendação da mesma especificação. Na alteração dimensional lançaram mão do microscópio de medida Leitz Witzlar. Da análise dos resultados os autores concluíram que a consistência ideal, é conseguida quando a mistura é erguida com a espátula sem gotejar por dez segundos ou quando sua fluidez permite aderência entre a espátula e placa de vidro a uma altura de $2 \mathrm{~cm}$, observaram também que o tempo de presa e alterações dimensionais são diretamente relacionados àproporção pó -líquido. A consistência clínica ideal (mais espessa) apresentou melhores resultados.

GROSSMAN ${ }^{57}$, no mesmo ano, testou a solubilidade dos cimentos AH26, Diaket, Tubli seal, Proco-sol, Kerr, Roth 801, Roth 811, Mynol, óxido de zinco eugenol e N2. Para isto, cilíndros metálicos com $1 \mathrm{~cm}$ de comprimento e 6 $\mathrm{cm}$ de diâmetro foram rigorosamente limpos e, posteriormente, colocados em placa de vidro e identificados. Foi realizado, então, o preenchimento dos tubos com cimentos e deixados àtemperatura ambiente para permitir a presa dos materiais. Posteriormente, colocou-se em um encubador a $37^{\circ} \mathrm{C}$ para certifiar-se que a presa dos cimentos tinha ocorrido desprovido de umidade. No dia seguinte pesou-se os tubos e então imergiu-os em solução composta de $98 \%$ de água 
deionizada e duas partes de caldo nutriente para simular o exsudato periapical mantendo os tubos nesta solução por uma semana, sendo que a renovação da solução era diária. Decorrido este período os tubos foram secos e pesados novamente, onde a perda de peso foi considerada o grau de solubilidade. Os resultados apontaram que o $\mathrm{AH} 26$ e o Diaket apresentaram o menor grau de solubilidade, enquanto que os cimentos que são derivados do óxido zinco eugenol apresentaram solubilidade variada.

BOSCOLO; BENATTI; GONÇALVES ${ }^{23}$, em 1979, avaliaram a radiopacidade de oito cimentos obturadores de canais radiculares, sendo eles: AH26, Endomethasone, Tubli-seal, Óxido de Zinco, Eugenol, Fill Canal, Diaket A, Trim Canal e Alpha Canal. Confeccionaram 10 corpos de prova de cada cimento contendo $5 \mathrm{~mm}$ de diâmetro e $3 \mathrm{~mm}$ de altura, e após 24 horas foram radiografados em filme oclusal: A leitura radiográfica de cada corpo foi realizada em fotomicroscópio II de Zeiss, acoplado a uma fotomultiplicadora RCAI Pa 8 Zeiss. Concluíram que o AH26 apresentou significantemente maior radiopacidade que os demais cimentos estudados.

ELIASSON; HAASKEN ${ }^{36}$, em 1979, averiguaram a densidade radiográfica de 26 materiais de impressão, sendo que os valores foram expressos em espessura de alumínio, equivalente. Posteriormente, sob condições clínicas simuladas somente dez dos materiais testados puderam ser distinguidos consistentemente da estrutura óssea, em radiografias periapicais. Verificaram também, maior dificuldade em detectar objetos com margem biselada do que objetos com espessura uniforme. Concluíram, ainda, pela análise dos resultados que a radiopacidade mínima requerida para a detecção de um corpo estranho no tecido gengival deve ser no mínimo de $2 \mathrm{~mm}$ de alumínio.

BEYER-OLSEN; ORSTAVIK ${ }^{19}$, no ano de, 1981 apresentaram um método padronizado e reproduzível para determinar a radiopacidade de materiais odontológicos. O método associa análise densitométrica de espécimes de tamanho padronizado com um objeto de alumínio, sob condições controladas de exposição e processamento do filme. Discutiram e avaliaram aspectos metodológicos, bem como realizaram a medida da radiopacidade de 40 materiais. 
Detectaram uma ampla variação entre os diferentes tipos de material pelo método proposto e pela avaliação clínica. Constataram que o exame visual feito por vários observadores não ofereceu medidas confiáveis da radiopacidade.

KAFFE et al. ${ }^{71}$, em 1983, avaliaram a radiopacidade de 14 marcas de guta-perchas encontradas no comércio, empregando o padrão recentemente elaborado para materiais endodônticos, que consiste na quantificação em $\mathrm{mm}$ de alumínio. A nova medida foi testada com o densitômetro. Verificaram que a radiopacidade de todas as guta-perchas testadas excederam grandemente 0 mínimo requerido. Entretanto, concluíram que a performance de algumas destas marcas não é satisfatória no uso clínico e sugeriram que o padrão seja revisado, elevando o requisito para a radiopacidade e outros testes de uso a ser realizado.

MORAES ${ }^{99}$, também em 1984, realizou uma sucessão de experimentos buscando esclarecer a causa do enegrecimento do AH26, mormente quando recebia $20 \%$ de hidróxido de cálcio no pó. Encontrou uma interação entre o bisfenol $A$, a hexametilenotretramina e o óxido de bismuto. A mesma também se dava substituindo-se esse último pelo subnitrato ou carbonato de bismuto. Este redundou em um discreto acinzentamento. Realizou, então, testes de alterações de cor, textura e volume, de radiopacidade, de consistência e tempo de presa, buscando outros radiopacificadores e resinas tipo bisfenol $A$ e respectivos endurecedores intentando assim, obter novos cimentos epóxicos viáveis para obturação de canais radiculares. Após 30 experimentos, obteve 4 formulações. Então, elas foram submetidas àvueles mesmos testes para comparações com outros materiais obturadores de canais radiculares, como o AH26 original ou com hidróxido de cálcio, o óxido de zinco e eugenol e guta-perchas de diversas procedências. Os ensaios culminaram com o de infiltração marginal, onde 216 dentes unirradiculados tiveram seus canais preparados e obturados com os cimentos experimentais e, com AH26 ou com óxido de zinco e eugenol. Após a impermeabilização de suas superfícies, exceto próximo ao forame apical eles foram imersos em solução de azul de metileno a $2 \%$, onde permaneceram por 72 horas e até 30 dias. Então, realizou, a secção longitudinal dos dentes e mediu a extensão de infiltração marginal das obturações. Após a análise dos testes de 
infiltração marginal e os testes de alteração de cor, e considerando os testes de consistência e de radiopacidade de todos os cimentos estudados, um dos cimentos experimentais teve desempenho destacado em relação ao $\mathrm{AH} 26$ original e ao cimento de óxido de zinco e eugenol, dentro dos padrões clínicos.

SAMPAIO; SATO ${ }^{117}$, no ano de 1984, averiguaram o escoamento apresentado pelos cimentos AH26, Fill canal, Alpha canal, Trincanal, N-Rickert e óxido de zinco e eugenol. Empregando placas de vidro dupla, com uma folha milimetrada entre elas, colocaram $0,1 \mathrm{~mL}$ de cimento na parte superior, e mantiveram as placas em posição vertical a $37^{\circ} \mathrm{C}$ e umidade relativa de $100 \%$. Nos períodos de 1, 24 e 72 horas e 1 semana, determinaram o escoamento apresentado pelos materiais. Os resultados mostraram que o AH26 demonstrou 0 maior escoamento, com o aumento através dos períodos avaliados. O segundo melhor resultado foi com o N-Rickert, sendo que para ele e os demais cimentos o escoamento não alterou após a primeira hora. O óxido de zinco e eugenol e o Alpha canal não apresentaram escoamento.

SATO; SAMPAIO ${ }^{120}$ analisaram, em 1985, a capacidade adesiva de três cimentos obturadores de canais radiculares, em três intervalos de tempo diferentes. Empregando um dispositivo de roldana, com peso para tracionar e verificar a adesividade do cimento àdentina, realizaram os testes nos períodos de 01, 24 e 168 horas após a espatulação do cimentos Rickert, N-Rickert e Alpha canal. Avaliando os resultados, concluíram que os cimentos Rickert e N-Rickert apresentaram boa adesividade com discreta superioridade por parte do Rickert porém, sem se diferenciarem estatisticamente. Esta adesividade foi maior nas primeiras 24 horas, com uma redução após 168 horas. O Alpha canal apresentou os piores resultados.

ZYTKIEVITZ; LIMA; SOBRINHO ${ }^{156}$, em 1985, estudaram o escoamento e tempo de presa inicial e final de seis cimentos obturadores de canais radiculares (N-Rickert, Trim Canal, Alpha Canal, Endomethasone, OZE e AH26). Para realização dos testes adaptaram as específicações de no 8 do grupo Brasileiro de Pofessores de Materiais Dentários e a $n^{\circ} 30$ da ADA. Pelos resultados obtidos puderam concluir que o $\mathrm{N}$-Ricket apresentaram maior escoamento, seguido pelo 
Trim Canal e AH26. Endomethasone e Alpha-Canal apresentaram resultados relativamente iguais entre si e o óxido de zinco e eugenol foi o que apresentou menor escoamento. Para o tempo de presa, esse foi maior para o óxido de zinco e eugenol, seguido pelo AH26 e o menor tempo foi do Trim Canal.

ORFALI; LILLEY; MOLOKHIA ${ }^{105}$, em 1987, investigaram a radiopacidade de dez materiais encontrados comercialmente. Para este teste, as normas 6876, 1986 da ISO e n 57, 1984 da ANSI/ADA estipulam espessura do espécime de 1 e $2 \mathrm{~mm}$ respectivamente. Nesse trabalho empregaram três espessuras das espécimes, 0,5mm; 1,3mm; e uma clinicamente estipulada, utilizando um canal artificial, no qual o cimento foi condensado com cones radiolúcidos. Realizaram radiografias em um aparelho $70 \mathrm{kV}$ com 16 impulsos, e uma distância foco-filme de $300 \mathrm{~mm}$. Mediram a radiopacidade com um densitômetro. Os valores de radiopacidade observados para os discos de 1,3mm de espessura variaram de 1,95 até $11,30 \mathrm{~mm}$ de alumínio, para aquelas de $0,5 \mathrm{~mm}$ de espessura foram de 1,37 a 3,26mm de alumínio equivalente. Os resultados dos diferentes materiais foram da mesma ordem para ambas as espessuras de materiais. Nos dentes simulados, os valores da radiopacidade foram de $0.42 \mathrm{a}$ $1,30 \mathrm{~mm}$ de alumínio equivalente, e a ordem dos materiais diferiram da ordem obtida nas duas espessuras, sendo isso possilvemente devido a diferença de viscosidade entre os materiais devendo, portanto, a viscosidade ser considerada quando da realização dos testes de radiopacidade dos materiais.

MARCIANO; MICHAILESCO ${ }^{94}$, no ano de 1989, determinaram a composição química confirmada na análise de difração do raios $\mathrm{X}$, de alguns cones de guta-perchas encontrados no comércio. Averiguaram, também, por meio de métodos de varredura colorimétrica diferencial a plasticidade das guta-perchas em resposta ̀̀ variações de temperatura. Observaram que houve grande heterogeneidade química entre os cones de guta-percha de diferentes marcas, bem como entre os pequenos e grandes da mesma marca. O sulfato de bário foi quem determinou a radiopacidade, e o óxido de zinco influenciou na plasticidade, enquanto que o excesso de guta-percha parecia produzir cones mais quebradiços os quais foram ruins na prática clínica. Pela varredura colorimétrica diferencial 
verificaram que as mudanças térmicas dentro da qual a guta-percha mostrou sua plasticidade máxima, não alterou quimicamente 0 material. Determinaram também, a temperatura máxima que os plastificadores devem possuir, devendo essa não exceder $60^{\circ} \mathrm{C}$.

ALAÇAM; GÖRGÜL; ÖMÜRLÜ3 ${ }^{3}$, em 1990, avaliaram três radiopacificadores diferentes para ser utilizado com o hidróxido de cálcio. Os materiais testados foram o diatrizoato meglumina, iotalamato meglumina e o sulfato de bário. Empregaram várias proporções dos radiopacificadores com hidróxido de cálcio, sendo que o veículo utilizado foi a água destilada. Após a manipulação das pastas, inseriram as misturas em moldes de teflon contendo 2 $\mathrm{mm}$ de altura e $10 \mathrm{~mm}$ de diâmetro, e então radiografaram, utilizando filme agfa. Com as radiografias em mãos, compararam a radiopacidade com densidade de escala do alumínio e de duas amostras de dentina. Verificaram que o diatrezoato meglumina $(69 \%)$ e o iotalamato meglumina $(60 \%)$ apresentaram resultados similares a $34 \%$ de sulfato de bário.

BIRMAN et al. ${ }^{21}$, em 1990, estudaram a biocompatibilidade, o escoamento e a adesividade dos cimentos Sealapex e N-Rickert. Para estudo da biocompatibilidade os autores empregaram camundongos, nos quais foram implantados lamínulas de vidro revestidas com o material. Nos períodos de 3, 7, 15,30 e 60 dias os animais foram sacrificados e a região preparada para análise microscópica. Analisaram, também, o escoamento, comparando com aquele do NRickert, onde os cimentos eram espatulados e $0,1 \mathrm{~mL}$ do material eram colocados na parte superior de uma placa de vidro de 30 por $30 \mathrm{~cm}$ que possuia na sua face posterior papel milimetrado, o conjunto placa e cimento era levado a estufa a $37^{\circ} \mathrm{C}$ e $100 \%$ de umidade, ficando em posição vertical, mediante o auxílio de suportes apropriados para a sustentação. Para a adesividade, o cimento era colocado entre duas fatias de dentina tratadas como no procedimento clínico, e após os tempos de 1, 24 e 168 horas, as amostras eram submetidas àtração. Na análise histológica verificou-se, para o Sealapex, que em todos os períodos de tempo ocorria uma reação tipo corpo estranho, não se encontrando pontos de calcificação. Quanto ao escoamento verificou-se que esse era discreto para o 
Sealapex e bem menor que aquele encontrado para o N-Ricket. $\mathrm{Na}$ análise da adesividade verificou-se que, ao final de 168 horas, esta era nula para o Sealapex, apresentando resultados bem menos favoráveis do que o N- Rickert.

KATZ et al. ${ }^{73}$, no mesmo ano, determinaram a radiopacidade de vários tipos de guta-percha e de discos de dentina. Prepararam discos com $1 \mathrm{~mm}$ de espessura de 15 diferentes cones de guta-percha comerciais e experimentais e testaram suas radiopacidades. A radiopacidade de $1 \mathrm{~mm}$ de dentina foi similarmente testada com um densitômetro. Todas as radiografias foram realizadas em filme do grupo $D$ e do grupo $E$ de sensibilidade. Verificaram que a radiopacidade média dos discos de guta-percha no filme do grupo $D$ de sensibilidade foi equivalente a 7,26 $\mathrm{mm}$ de alúminio e $7,53 \mathrm{~mm}$ no filme do grupo $E$ de sensibilidade excedendo, significantemente, o mínimo requerido que é de 3 $\mathrm{mm}$ de alumínio. As amostras de dentina foram uniformes em suas radiopacidades e equivalente a $1 \mathrm{~mm}$ de alumínio.

GETTLEMAN; MESSER; ELDEEB ${ }^{50}$, em 1991, avaliaram a influência da Smear Layer na adesão de cimentos endodônticos, àdentina. Utilizaram 120 espécimes, sendo 40 por cada cimento, 20 com e 20 sem Smear Layer. Os dentes anteriores superiores foram fraturados longitudinalmente e a superfície interna foi preparada. Em uma metade de cada dente foi deixado a Smear Layer e na outra metade foi removida empregando o EDTA a $17 \%$ por 3 minutos, seguido pela irrigação com hipoclorito de sódio a 5,25\%. Utilizaram para testar a adesão um aparato especialmente desenhado, e o cimento foi colocado em um recipiente com $4 \mathrm{~mm}$ de diâmetro com $4 \mathrm{~mm}$ de profundidade, o qual incidiu com a superfície dentinária em um ângulo de 90ㅜ , e então se armazenou o conjunto a 37으 e 100\% de umidade por 7 dias. Após esse período realizaram os testes de tração. Os resultados mostraram diferenças significantes entre o AH26, Sutan e o Sealapex, com o AH26 sendo mais forte e o Sealapex o mais fraco. A única diferença significante, com respeito àpresença ou ausência de Smear Layer foi encontrada com o AH26 o qual se uniu melhor àdentina quando a Smear Layer foi removida.

RAY; SELTZER ${ }^{114}$, no mesmo ano, testaram várias características físicas de um novo cimento de ionômero de vidro. Averiguaram o tempo de presa, 
facilidade de manipulação, adaptação, adesão à parede dentinária e radiopacidade. Realizaram, também, microscopia eletrônica de varredura com auxílio de microsondas para constatar a composição de cada material. Todas as propriedades do ionômero de vidro foram comparadas com a do cimento de Grossman. Os resultados indicaram, que com relação as propriedades testadas, o cimento de ionômero de vidro foi superior ao cimento de Grossman.

KAZEMI; SAFAVI; SPANGBERG ${ }^{75}$, em 1993, estudaram em períodos prolongados, as alterações dimensionais dos cimentos Endofill, AH26, óxido de zinco e eugenol e Endomethasone. Averiguaram, também, o tempo de presa dos respectivos materiais. Para o teste de alterações dimensionais, espatularam os cimentos e injetaram em finas camadas na parede interna de pipetas de vidro com $1 \mathrm{~mm}$ de diâmetro. Preencheram as pipetas com água deionizada e o menisco foram registradas periodicamente durante 180 dias. Após esse período, removeram a água das pipetas e as amostras foram secas, e então mediram a massa e o volume dos cimentos. O AH26 e o Endofill apresentaram uma expansão inicial seguida de uma perda volumétrica. Os dois cimentos a base de óxido de zinco e eugenol, iniciaram com uma perda após poucas horas da mistura. Para o AH26 verificaram que a primeira perda volumétrica ocorreu durante os primeiros trinta dias, enquanto que para o Endofill foi após trinta dias. Averiguaram, também, que a menor alteração dimensional, ocorreu com o Endofill. Com relação ao tempo de presa, esse foi de 2,5 horas para o Endofill, 4 horas para o óxido de zinco e eugenol, 9 horas para o Endomethasone e 12 horas para - AH26. Concluíram que uma significante alteração dimensional e perda de volume contínua pode ocorrer com os cimentos endodônticos.

DEGEE; WU; WESSELINK ${ }^{31}$, em 1994, testaram a capacidade seladora, contração de presa e tempo de presa do cimento ionomérico Ketacendo, comparando os resultados ànueles o btidos pelo $\mathrm{AH} 26$ silver free. Utilizaram 60 cilindros com comprimento de $8 \mathrm{~mm}$ e diâmetro de $4 \mathrm{~mm}$ que foram preparados a partir de dentina radicular bovina, que tiveram a Smear Layer removida, antes de serem cimentados juntos, deixando $01 \mathrm{~mm}$ de espaço. Isto resultou em 15 amostras cimentadas com Ketac-endo e 15 com AH26. Após cobrirem a superfície 
lateral com verniz, conectaram o final de cada cilindro a um tubo contendo água com uma pressão de $120 \mathrm{KPa}$ (1,2 atm). Determinaram a infiltração, medindo-se a penetração de bolhas na interface dente e cimento. $O$ tempo de presa foi determinado com o auxílio de um reômetro e a contração de presa através de um dilatômetro de mercúrio. Verificaram que o Ketac-endo infiltrou significantemente mais que o AH26. Observaram, ainda, que a falha adesiva foi de $88 \%$ para o Ketac-endo e $15 \%$ no AH26. Detectaram que a infiltração ocorreu mais na interface dentina/cimento para o Ketac-endo e através de fraturas coesivas para o AH26. O tempo de presa registrado foi de 34 horas para o AH26 e 2,5 horas para o Ketac-endo. Quanto àcontração de presa, observou -se um valor de $2 \%$ para 0 AH26 após 70 horas, e 3,6\% para o Ketac-endo após 15 horas.

FIDEL et al. ${ }^{44}$, no mesmo ano de 1994 , avaliaram a adesão àdentina dos cimentos Sealer 26, Apexit, CRCS e Sealapex, utilizando o Fill canal como controle. Usando um método que registrava a força tênsil, os autores verificaram que o Sealapex e Apexit apresentaram as menores adesões. Sem o uso de EDTA, o CRCS foi o que apresentou maior adesão, seguido do Sealer 26. Com o uso do EDTA o Sealer 26 demonstrou a melhor adesividade àdentina. Concluíram que a aplicação do EDTA àdentina aumentou a adesão dos cimentos, com exceção do Sealapex.

FIDEL et al. ${ }^{45}$, em 1994, estudaram a solubilidade e a desintegração de cimentos endodônticos que contêm hidróxido de cálcio. Testaram os cimentos Sealer 26, CRCS, Sealapex e Apexit. Espatularam os materiais e os introduziram em moldes de teflon e incubaram o conjunto a $37^{\circ} \mathrm{C}$, com $95^{\circ}$ de umidade. Decorrido um período três vezes maior que o do tempo de presa, as amostras foram removidas dos moldes, pesadas e imersas em $50 \mathrm{~mL}$ de água deionizada e, então, incubadas novamente a $37^{\circ} \mathrm{C}$, por uma semana. Concluído o período, as amostras foram retiradas da água e, então, desumidificadas por 24 horas, sendo pesadas novamente. Verificaram que o Sealer 26 e o Apexit se portaram como os menos solúveis, seguidos pelo CRCS. O Sealapex apresentou alta solubilidade, com valores bem acima do preconizado pela América Dental Association. 
SAVIOLI; SILVA; PÉCORA ${ }^{119}$, também em 1994, estudaram a influência de cada componente químico do cimento de Grossman sobre as propriedades físicas de escoamento, tempo de presa e espessura de filme. Realizaram os experimentos de acordo com a especificação $\mathrm{n} \cong 57$ da ADA. Aviaram-se 7 fórmulas diferentes a partir do óxido de zinco puro até a fórmula original do cimento de Grossman. Observaram que a resina natural é aceleradora do tempo de presa e responsável pelo escoamento. O tetraborato de sódio anidro funciona como retardador da reação química entre o óxido de zinco e eugenol, porém, não consegue realizar essa função quando da presença de resina natural. A espessura de filme só é obtida quando a proporção do óxido de zinco e da resina natural é de 100:65.

FIDEL et al. $^{46}$, em 1995, estudaram a alteração dimensional de cimentos que continham hidróxido de cálcio em sua composição, sendo eles: Sealer 26, CRCS, PR sealer (cimento confeccionado no laboratório de pesquisa em endodontia da FORP - USP), Apexit, Sealapex. Confeccionaram corpos de prova que foram medidos antes e após a imersão em água deionizada por 30 dias. Com as medidas em mãos, determinaram a alteração dimensional. Constataram que o cimento Sealapex não resistiu ao experimento, pois desintegrou-se. Todos os cimentos sofreram ligeira expansão, com os maiores índices sendo encontrados com o PR sealer e os menores com o Sealer 26.

FIDEL et al. ${ }^{47}$, no mesmo ano, constataram, utilizando a especificação no 57 da ADA, o tempo de endurecimento dos cimentos Apexit, Sealapex, CRCS e Sealer 26. Os cimentos eram espatulados e colocados em anéis metálicos de 10 $\mathrm{mm}$ de diâmetro e $2 \mathrm{~mm}$ de altura, fixados com auxílio de cera em uma placa de vidro de $1 \mathrm{~mm}$ de espessura, $25 \mathrm{~mm}$ de largura e $75 \mathrm{~mm}$ de comprimento. Após 120 segundos do início da mistura, o conjunto era colocado em um recipiente plástico com vedação hermética e umidade relativa de $95 \%$, que foi levado a uma temperatura de $37^{\circ} \mathrm{C}$. A presa do cimento foi constatada com o auxílio de uma agulha Gilmore de 100 gramas de peso e $2 \mathrm{~mm}$ de ponta ativa. Os resultados mostraram que o CRCS apresentou um tempo de presa de 23 minutos, Apexit de 
1 hora e 30 minutos, Sealer 26 de 41 horas e 22 minutos e o Sealapex de 45 horas e 34 minutos.

TORABINEJAD et al. ${ }^{140}$, também em 1995, determinaram a composição química, $\mathrm{pH}$ e radiopacidade do agregado de trióxido mineral(MTA), e tambem realizaram a análise comparativa do tempo de presa, força compressiva e solubilidade do material com o amálgama, Super EBA e IRM. Espectrofotômetro de energia dispersiva de raios $X$ em conjunto com microscopia de varredura foram utilizados para determinar a composição do MTA, enquanto que o pH foi aferido com auxílio de um pHmetro com eletrodo compensado pela temperatura. $\mathrm{Na}$ radiopacidade empregaram o método descrito na norma 6876 da ISO. Já na avaliação do tempo de presa e força compressiva empregaram o método proposto pela instituição de padronização inglesa. Para averiguação da solubilidade, 0 método utilizado foi o proposto pela ADA com algumas modificações. Os resultados mostraram que as principais moléculas presentes no MTA são os íons cálcio e fósforo. Quanto ao pH observaram que ele é inicialmente de 10,2 e alcança 12,5 após 3 horas. MTA é mais radiopaco que o Super EBA e o IRM, possuindo um valor de $7,17 \mathrm{~mm}$ de alumínio equivalente. Quanto ao tempo de presa verificaram que era mais rápido para o amálgama, 4minutos e para o MTA ele foi o mais longo, 2 horas e 45 minutos. Na força compressiva essa foi de 40MPa em 24 horas, aumentando para $67 \mathrm{MPa}$ após 21 dias. Na avaliação da solubilidade, exceto para o IRM, nenhum dos outros materiais se mostrou solúvel sob as condições desse estudo.

SHAH et al. ${ }^{124}$, em 1996, averiguaram a radiopacidade de alguns materiais obturadores retrógrados, sendo eles: amálgama, Kalzinol, IRM, Super EBA, Vitrebond, Fuji II LC, Chemfil e guta-percha. Os materiais foram espatulados e inseridos em anéis contendo $10 \mathrm{~mm}$ de diâmetro e $1 \mathrm{~mm}$ de altura. Radiografaram os anéis contendo os materiais em estudo e as radiografias foram, então, avaliadas densitometricamente, comparando a radiopacidade com a espessura de alumínio correspondente. Verificaram que os cimentos de ionômero de vidro (Vitrebond, Fuji II LC, Chemfil) apresentaram radiopacidade abaixo do padrão internacional para cimentos endodônticos ( $<3 \mathrm{~mm}$ de alumínio), os três 
materiais com o óxido de zinco e eugenol (Kalzinol, Super EBA, IRM) possuiam radiopacidade entre 5 e $8 \mathrm{~mm}$ de alumínio e a guta-percha demonstrou uma radiopacidade de 6,1 $\mathrm{mm}$ de alumínio, enquanto que o amálgama apresentou a melhor radiopacidade, maior que $10 \mathrm{~mm}$ de alumínio. Os autores concluíram que o material a ser empregado em obturações retrógradas deve apresentar radiopacidade maior que os cimentos endodônticos.

PETRY et al. ${ }^{109}$, no ano de 1997 , avaliaram utilizando o sistema de imagem digitalizada da Acu Ray a radiopacidade dos cimentos N-Rickert, Fill canal, Sealer 26 e Sealapex. Os cimentos foram espatulados e inseridos no interior de tubos, e posteriormente levados a estufa a $37^{\circ} \mathrm{C}$ com umidade de $95 \%$ por um período de 24 horas e o tempo instruído pelo fabricante para a presa do material. Posteriormente, as amostras foram estocadas em um recipiente úmido por 14 dias. Após esse período, as amostras foram submetidas aos testes de radiopacidade empregando o sistema de imagem digitalizada Acu Ray. Os resultados mostraram que não houve diferença estatisticamente significante na radiopacidade, quando o material foi deixado 24 horas ou o tempo instruído pelo fabricante para a presa. O Sealapex apresentou a menor densidade ótica porém, sem se diferenciar estatisticamente dos demais que apresentaram resultados semelhantes.

ALMEIDA; ANTONIO; MOURA ${ }^{7}$, em 1998, analisaram a radiopacidade de grupos obturadores de canais, sendo eles: AH26, N-Rickert, Sealapex, Fill Canal. Os cimentos foram espatulados e inseridos em moldes de plástico apresentando $5 \mathrm{~mm}$ de diâmetro e $2 \mathrm{~mm}$ de altura seguindo especificação $\mathrm{n}$. $57 \mathrm{da}$ American Dental Association. Posteriormente, levaram os conjuntos àestufa a $37^{\circ} \mathrm{C}$ por 24 horas. Empregaram dois copos de prova por cimento e após a presa realizaram a radiografia das amostras em filme oclusal (Ektaspeed plus) e, então, mediram a radiopacidade com auxílio de um fotodensitômetro. Os resultados mostraram que o N-Rickert e o FillCanal apresentaram maior radiopacidade, apresentando densidade radiográfica de 0,46 , enquanto que o AH26 apresentou valores de 0,78 e o Sealapex foi o que atenuou mais a passagem da luz, apresentando valor de 0,90 . 
ONO; MATSUMOTO ${ }^{104}$, em 1998, avaliaram as propriedades físicas (selamento, radiopacidade, fluidez, tempo de trabalho e solubilidade) de um novo cimento obturador $\mathrm{CH} 61$. Comparando com aquelas do AH26, Sealapex e Canals. A capacidade seladora foi realizada com tubos de vidro. A fluidez utilizando-se dois métodos (Grossman e ISO 1986). A radiopacidade, tempo de trabalho e solubilidade de acordo com a norma da ISO 1986. Averiguaram pelos resultados, que em 24 horas não ocorreu infiltração no $\mathrm{CH} 61$ e houve diferença significante com os demais cimentos. Para análise da fluidez, os resultados diferiram de método para método sendo que no de Grossman o AH26 apresentou maiores valores, enquanto que no da ISO o Canals obteve os valores mais elevados. $\mathrm{Na}$ radiopacidade, ela diminuiu na seguinte ordem: $\mathrm{AH} 26$, Canals, $\mathrm{CH} 61$ e Sealapex. Para solubilidade ela foi mais baixa para o $\mathrm{CH} 61$. Concluíram que o $\mathrm{CH} 61$ apresentou excelente capacidade seladora e baixa solubilidade. 
3 - PROPOSIÇÃO 
3 - PROPOS IÇ $\tilde{\mathcal{A} O}$

Diante do exposto na introdução e da justificativa pertinente, nos propusemos a avaliar a influência do acréscimo 5 e 10\% em peso de hidróxido de cálcio ao AH Plus em relação:
a) Ao seu tempo de presa;
b) À sua radiopacidade;
c) À sua capacidade seladora, pela análise da infiltração marginal de corante azul de metileno a $2 \%$;
d) Ao seu escoamento;
e) Ao seu pH e liberação de íons cálcio. 


\section{4 - MATERIAL E MÉTODOS}




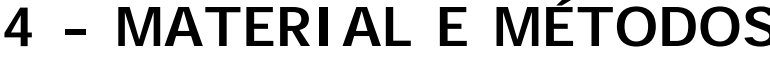

Foi utilizado para a realização deste trabalho o cimento $\mathrm{AH}$ Plus (Figura 1) cuja composição está apresentada abaixo. A partir desse cimento foram preparados outros dois experimentais, acrescentando-Ihe proporcionalmente $5 \% \mathrm{e}$ 10\% de hidróxido de cálcio em peso.

Composição do AH Plus:

- Pasta Epóxi: Diepoxi; tungstênio de cálcio; óxido de zircônio; aerosol; e pigmento.

- Pasta Amina: Amina 1-adamantane; N.N'dibenzil-5-oxanonandiamine-1,9; TCD-diamina; tungstênio de cálcio; óxido de zircônio; aerosol; óleo de silicone.

\section{1 - MÉTODOS}

\subsection{2 - ANÁLISE DA INFILTRAÇÃO MARGINAL (CAPACIDADE SELADORA)}

Para este e todos os testes, o cimento AH Plus, que é apresentado na forma de duas pastas, conforme já salientado, foi sempre proporcionado colocando-se partes iguais das pastas, de acordo com as instruções do fabricante. Para as modificações, as duas pastas eram pesadas e a elas se acrescentava $5 \%$ ou $10 \%$, em peso, de hidróxido de cálcio, em pó, proporcionado ao peso total.

Foram utilizados para essa análise 80 dentes caninos humanos recémextraídos, os quais, inicialmente foram armazenados em formalina a $10 \%$. Efetuou-se a abertura coronária de maneira convencional até obtenção de livre acesso ao canal radicular. A padronização do forame foi realizada dilatando o canal em toda sua extensão até a lima tipo $\mathrm{K} \mathrm{n}^{\circ} 30^{* *}$. A instrumentação do canal foi realizada por meio da técnica escalonada regressiva, estabelecendo-se o degrau apical de instrumentação a $1 \mathrm{~mm}$ aquém da extensão total e tendo como instrumento de memória a lima tipo $K \mathrm{n}^{\circ}-45$, realizando-se o escalonamento até a

\footnotetext{
* Dentsply De Trey, Konstanz, Alemanha

** Maillefer, Baillanges, Suiça
} 
lima tipo $K \mathrm{n}^{\circ}$ 60. Durante toda instrumentação foi efetuada irrigação com hipoclorito de sódio a $1 \%$, cerca de $1 \mathrm{~mL}$ a cada troca de instrumento e ao final EDTA* por 3 minutos e, então, finalizou-se a irrigação com soro fisiológico. Após a instrumentação os dentes foram impermeabilizados externamente passando-se duas camadas de araldite de presa lenta ${ }^{* *}$ e uma de esmalte para unhas. Concluída a impermeabilização dividiu-se os dentes em quatro grupos de vinte elementos cada, de acordo com o cimento obturador empregado:

- Grupo I: cimento AH Plus

- Grupo II: experimental I - cimento AH Plus com 5\% de hidróxido de cálcio (MERCK)

- Grupo III: experimental II - cimento AH Plus com 10\% de hidróxido de cálcio (MERCK)

- Grupo IV: controle - cimento de óxido de zinco e eugenol. ${ }^{\star \star}$

Após a seleção do cone principal de guta-percha, de acordo com o diâmetro cirúrgico observado na extensão de trabalho, efetuou-se a obturação.

A técnica de obturação foi a do cone único em que se levou o cimento antes no canal com auxílio de uma espiral Lentullo $n-3^{* * *}$ e, então, introduziu-se 0 cone principal, após averiguação do extravazamento do cimento. O excesso de cone no interior da câmara pulpar foi removido com condensadores aquecidos e a limpeza final foi efetuada utilizando-se bolinhas de algodão e álcool para realização do selamento provisório com Cimpat $e$ as coroas foram impermeabilizadas com cera fundida. Posteriormente, os dentes foram imersos em solução aquosa de azul de metileno a $2 \%$ por sete dias a $37^{\circ} \mathrm{C}$. Após a conclusão do período, removeu-se os mesmos do corante, lavou-os em água corrente, livrou-os da impermeabilização e, então, foram clivados no sentido vestíbulo-lingual após confecção de sulcos na vestibular e lingual, obtendo-se duas hemissecções. A hemissecção (Figuras 2, 3, 4, 5) mais espessa foi conservada para leitura da infiltração e a outra, desprezada. A leitura da

\footnotetext{
* Biodinâmica Química e Farmacêutica Ltda., Ibiporã, Brasil

*** Ciba-Geigy Química S.A., Taboão da Serra, Brasil

${ }^{* * *}$ SS White, Rio de Janeiro, Brasil
} 
infiltração foi realizada em microscópio ótico com auxílio de ocular micrometrada $^{* * * \star}$. Esta leitura foi realizada pela técnica de planimetria, utilizandose uma ocular milimetrada com aumento de $12,5 \mathrm{X}$ e objetiva $4 \mathrm{X}$. Nesta técnica a calibragem do microscópio é realizada com auxílio de uma régua micrométrica, a qual possui um círculo cujo diâmetro corresponde a $1 \mathrm{~mm}$. Este $1 \mathrm{~mm}$, nas condições de ocular micrometrada $12,5 \mathrm{X}$ e objetiva de $4 \mathrm{X}$ correspondia a 4,1 divisões da ocular. Para a leitura, as hemissecções contendo a obturação e a possível marca da infiltração, foram fixadas em lâminas de vidro, para microscopia, com auxílio de cera utilidade e levadas ao microscópio, sendo iluminadas com luz direta. As medidas foram realizadas a partir da ponta do cone principal, caminhando-se em direção cervical. Os números encontrados foram anotados em fichas e, posteriormente, transformados em milímetros. Dois examinadores fizeram a leitura da infiltração marginal, independentemente. Qualquer resultado discrepante em uma mesma amostra era discutido por ambos, chegando-se a um denominador comum. Das medidas encontradas pelos dois examinadores, foram calculadas as médias obtendo-se, assim, o resultado da infiltração marginal. Com os resultados em mãos, efetuou-se o confronto estatístico empregando para isso o teste de KRUSKAL-WALLIS para análise global e o teste de MILLER para comparações individuais.

\subsection{2 - ANÁLISE DO TEMPO DE PRESA}

A determinação do tempo de presa dos cimentos sob teste foi realizada por adaptações à Especificação número 8 da ASSOCIAÇÃO DENTÁRIA AMERICANA preconizada para cimentos de fosfato de zinco conforme sugestões de MORAES ${ }^{99}$.

O tempo de presa foi registrado em função da maturação dos corpos de prova a $37^{0} \mathrm{C}$ em condições ambientais e em umidade relativa de $100 \%$.

\footnotetext{
${ }^{* * * * *}$ Maillefer, Baillanges, Suiça

***** Carl Zeiss, Alemanha
} 
Os cimentos foram proporcionados, espatulados e vertidos em anéis metálicos com 10mm de diâmetro interno e $2 \mathrm{~mm}$ de altura. Após serem levados à estufa, a superfície dos mesmos foram tocadas com a agulha de Gillmore de 453,6 gramas de peso. Sendo que a presa final foi considerada quando a agulha deixou de marcar a superfície. Três testes foram feitos para cada material.

\subsection{3 - TESTES DE CONSISTÊNCIA DOS CIMENTOS (ESCOAMENTO)}

A consistência do cimento foi avaliada usando método similar ao da Especificação número 8 da ASSOCIAÇÃO DENTÁRIA AMERICANA para cimento de fosfato de zinco, conforme sugestão de MORAES ${ }^{99}$, que corresponde hoje a norma $\mathrm{n}^{0} 57$.

$O$ teste foi conduzido tomando-se $0,5 \mathrm{~mL} \pm 0,02 \mathrm{~mL}$ do cimento devidamente proporcionado e espatulado, colocando-se sobre uma placa de vidro plana e lisa. Decorridos três minutos do início da espatulação, outra placa de vidro lisa e plana foi colocada sobre o cimento recebendo um peso que somado ao dela, completou 120gramas. Todo conjunto foi levado à estufa a $37^{\circ} \mathrm{C}$ e $100 \%$ de umidade relativa. Após 10 minutos do início da espatulação, o peso foi removido e mediu-se o diâmetro do círculo formado pelo cimento. Este foi medido duas vezes - na menor e maior dimensão - considerando-se a média, em milímetros, como medida de consistência padrão. Foram realizados 3 testes para cada material.

\subsection{4 - DETERMINAÇÃO DA RADIOPACIDADE}

\subsubsection{1 - Confecção dos corpos de prova}

Corpos de prova cilíndricos foram preparados com os cimentos em teste, com guta-percha de várias procedências e cilindros de dentina de mesma espessura para comparações individuais.

Os cimentos devidamente proporcionados e espatulados foram vertidos, com os devidos cuidados para evitar inclusão de bolhas de ar, em anéis 
de metal com $10 \mathrm{~mm}$ de diâmetro e $2 \mathrm{~mm}$ de altura (Figura 6), os quais foram colocados sobre placas de vidro plana e lisa. Outra placa foi assentada e comprimida sobre os anéis para planificar a superfície e uniformizar a espessura do corpo de prova. O conjunto foi conservado a $37^{\circ} \mathrm{C}$. Depois da presa dos cimentos, as placas foram retiradas e as espessuras dos corpos de prova conferidas com paquímetro. Qualquer aumento foi compensado por raspagem das superfícies dos mesmos.

Já os cones de guta-percha foram amolecidos pela ação do calor e compactados dentro dos anéis de metal sobre placas de vidro vaselinadas, usando-se calcadores de amálgama de tamanhos apropriados. Suas superfícies foram regularizadas, tornando os corpos de prova aptos a serem radiografados.

Os cilindros de dentina foram obtidos de raízes de dentes humanos. Estes foram seccionados com disco de carburundun, obtendo-se cilindros com $2 \mathrm{~mm}$ de espessura, medidas com auxílio de um paquímetro.

\subsubsection{2 - Análise e determinação da radiopacidade por imagem digital}

Todos os corpos de prova foram preliminarmente radiografados, para constatar presença ou não de bolhas, onde se descartou os que apresentaramnas. Os aprovados foram dispostos sobre uma placa ótica com identificações, conjuntamente com um penetrômetro de alumínio (Figura 6).

As placas foram sensibilizadas com um aparelho de raios $X$ XR6010* da Gnatus, com quilovoltagem de $60 \mathrm{kV}$, miliamperagem de $10 \mathrm{~mA}$ com tempo de exposição variando de 0,3s. A distância foco/filme foi de $40 \mathrm{~cm}$.

Após a sensibilização, as placas ópticas foram "scaneadas" no Digora* (Figura 7) e, então, com a medida da densidade foi determinado o valor da radiopacidade em densidade radiográfica a qual foi também convertida em milímetros de alumínio. A conversão foi realizada determinando-se a densidade radiográfica correspondente a cada milímetro de alumínio, de acordo com cada

\footnotetext{
${ }^{*}$ Gnatus, Equipamentos Médico-Odontológicos, Ribeirão Preto, Brasil

*** Digora, Soredex, Finlândia
} 
intervalo entre os milímetros, isto é, entre 1 e 2, 2 e 3, 3 e 4, etc. Para se obter o valor de cada material, observou-se em qual intervalo ele estava, ou seja, se o valor da sua densidade estava, por exemplo, entre o intervalo 4 e 5, 5 e 6 , etc. A cada intervalo o $1 \mathrm{~mm}$ corresponde a valores distintos; por exemplo, a diferença entre o 4 e 5 é 16,83 ( $(5)=162,07-(4)=145,24)$ e entre 5 e 6 é 14,39 $((6)=176,46$ $(5)=162,07)$. Assim se, por exemplo, a densidade do material apresentasse 0 valor entre 5 e 6 , o cálculo era realizado da seguinte maneira. Do valor da densidade do material subtraia-se o valor correspondente a $5 \mathrm{~mm}$ de alumínio, essa diferença era convertida em milímetros de alumínio utilizando-se para o cálculo uma regra de três simples. Exemplo:

- Valor correspondente a $5 \mathrm{~mm} \mathrm{Al}=162,07$

- Valor da densidade do material $=170,16$

- Diferença entre densidade material/5mm Al = 8,09

- Diferença entre densidade de 5 e $6 \mathrm{~m} \mathrm{Al}=14,39$

- Cálculo do valor da densidade do material em mm de Al.

- Se o valor 14,39 corresponde a $1 \mathrm{~mm}$ de Al. (entre 5 e 6) 8,09 corresponderá a $X$; isto é: 14,39----------1

$$
\text { 8,09--- } X \quad X=0,56
$$

Assim, o valor 0,56 , sendo adicionado ao valor 5 têm-se o valor do material em milímetros de alumínio, isto é, 170,16 em densidade radiográfica é correspondente a 5,56 mm Al.

Os valores dos materiais e da dentina foram comparados entre si tanto nos valores de densidade radiográfica como em $\mathrm{mm}$ de Al pelo ANOVA a 1 critério para comparação global e teste de Tukey-Kramer para os confrontos individuais.

\subsection{5 - ANÁLISE DO pH E LIBERAÇÃO DE ÍONS CÁLCIO}

Para avaliação do pH e liberação de íons cálcio proporcionados pelos cimentos foram utilizados 40 tubos com diâmetro de $1,5 \mathrm{~mm}$ e comprimento de $1 \mathrm{~cm}$ que foram preenchidos com os materiais em estudo e, posteriormente imersos em frascos contendo $20 \mathrm{~mL}$ de água deionizada e, então, os vidros foram 
selados hermeticamente e levados àestufa a $37{ }^{\circ} \mathrm{C}$. Nos períodos de 24 horas, e 48 horas, 7 dias, 14dias e 30 dias, $4 \mathrm{~mL}$ da água eram retirados e a análise do $\mathrm{pH}$ e liberação de cálcio era realizada. Foram confeccionadas 10 amostras para cada grupo.

\subsubsection{1 - Leitura do $\mathrm{pH}$}

A leitura do $\mathrm{pH}$ foi efetuada com o auxílio de um pHmetro*. Tomou-se, sempre o cuidado em verificar-se a precisão do aparelho realizando-se medições constantes de tampões conhecidos em pH 4, 7 e 9.

\subsubsection{2 - Leitura da liberação de íons cálcio}

Para monitoração do $\mathrm{Ca}^{++}$foi empregado um espectrofotômetro de

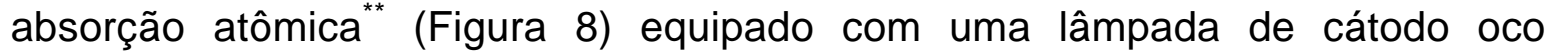
específica para o cálcio. As condições de operação foram:

- Corrente da lâmpada: 3 miliamperes

- Combustível: Acetileno

- Suporte: Oxigênio

- Estequiometria: Redutor

Para o comprimento da onda e fenda foram efetuados testes pilotos para a determinação correta.

Para prevenir possíveis interferências de fosfato e metais alcalinos, as amostras e padrões foram diluídas em EDTA 10\%, e a vidraria a ser empregada previamente lavada com ácido nítrico.

Uma solução padrão estoque de $10 \mathrm{mg} \%$ foi diluída em EDTA $10 \%$ de forma a se obter as seguintes concentrações: 0,025 mg\%; 0,05 mg\%; 0,1 mg\%; $0,2 \mathrm{mg} \%$ e $0,5 \mathrm{mg} \%$.

As amostras foram diluídas conforme o necessário.

\footnotetext{
* Corning Incorporated, New York, Estados Unidos

** Varion Co., São Paulo, Brasil
} 
Para levar o aparelho a zero de absorvância, empregou-se como branco o EDTA $10 \%$.

Os cálculos da liberação foram efetivados por meio da equação da reta da curva padrão.

A leitura da liberação de íons $\mathrm{Ca}^{++}$foi efetuada nos mesmos períodos utilizados para a leitura do $\mathrm{pH}$.

Com os dados em mãos os mesmos foram submetidos àanálise estatística, empregando-se a análise de variância a dois critério e comparações individuais pelo teste de TUKEY-KRAMER. 


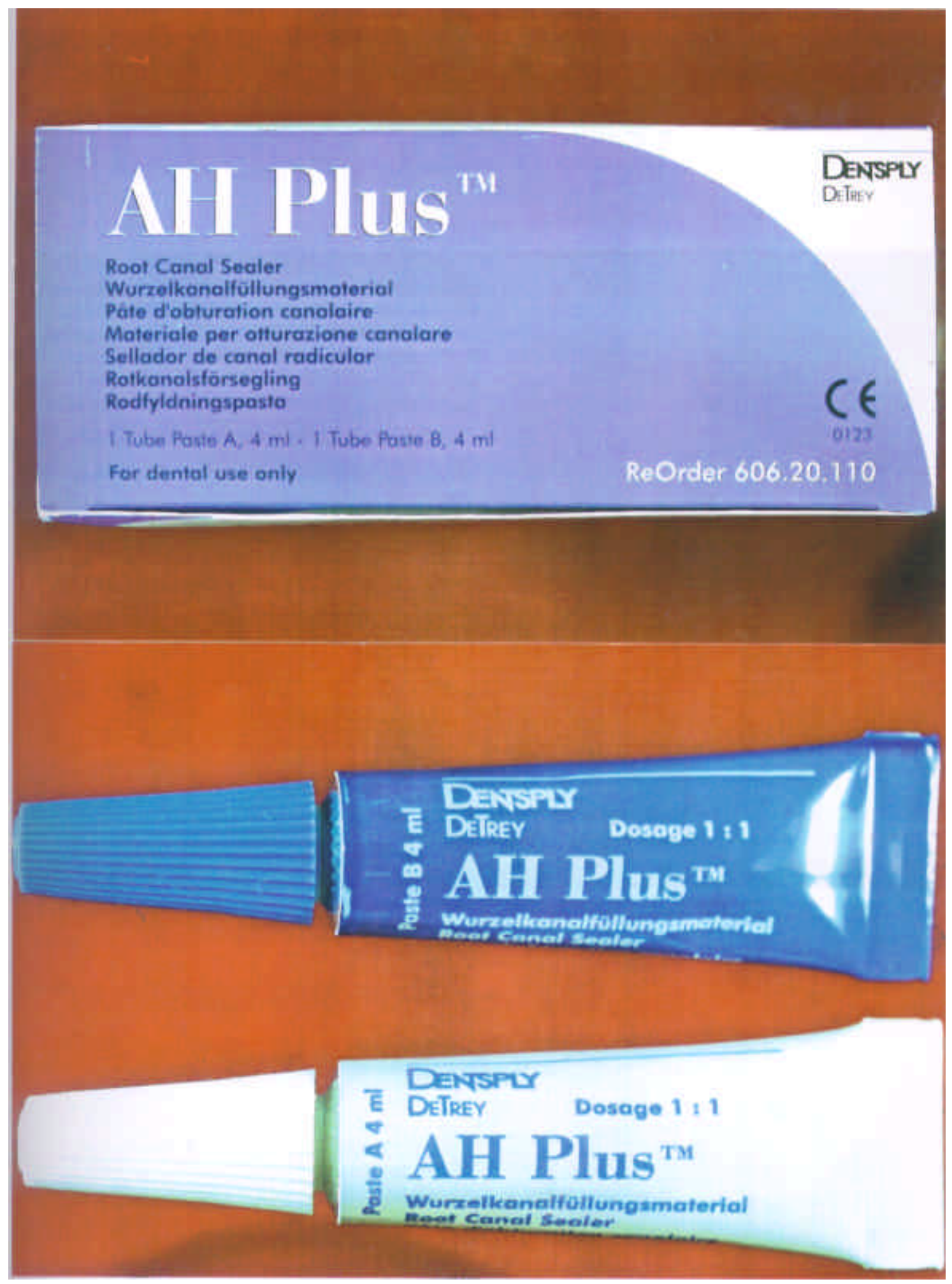

FIGURA 1 - Cimento AH Plus puro 


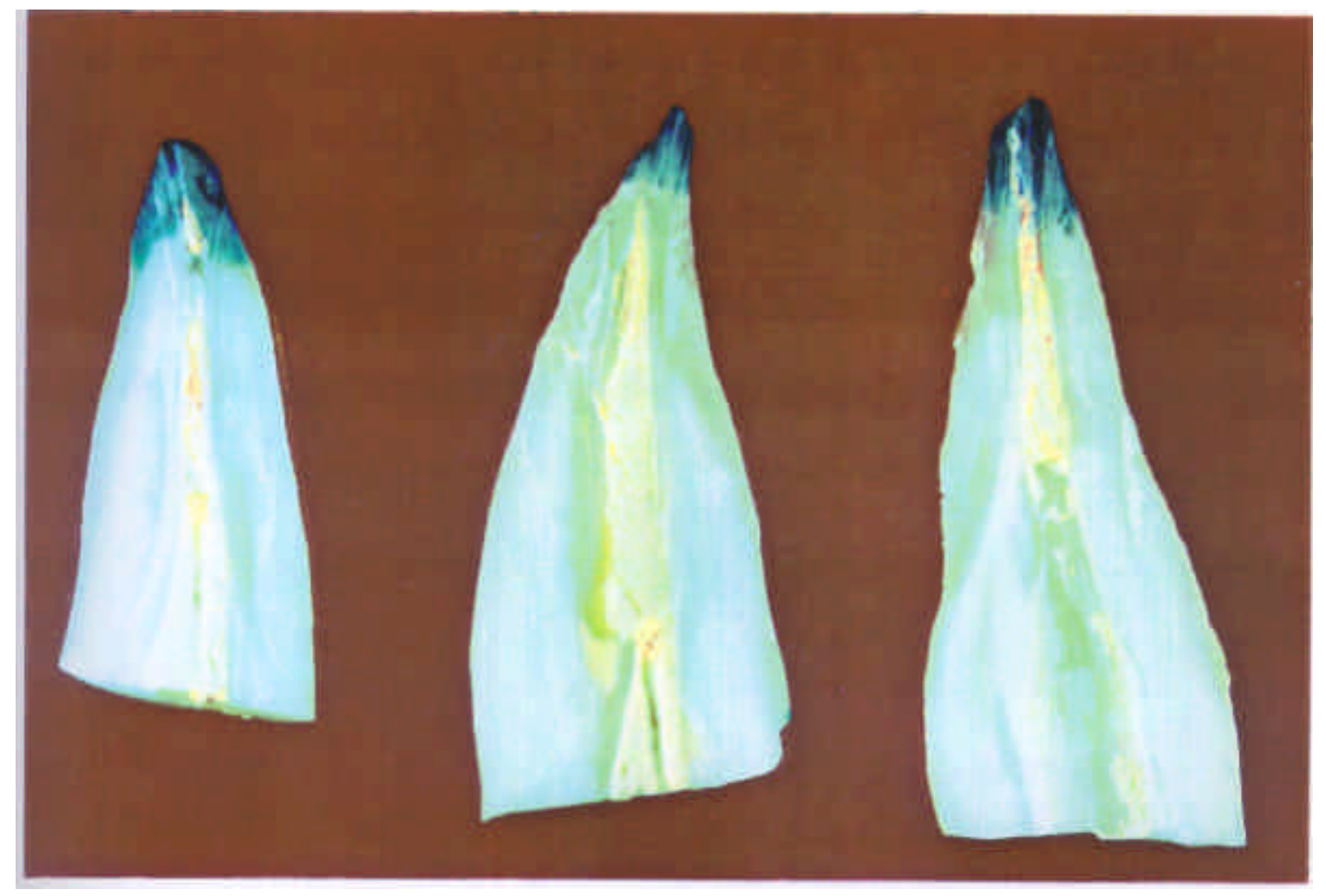

FIGURA 2 - Hemisecções com os canais obturados com o AH Plus puro e utilizados para determinação da infiltração 


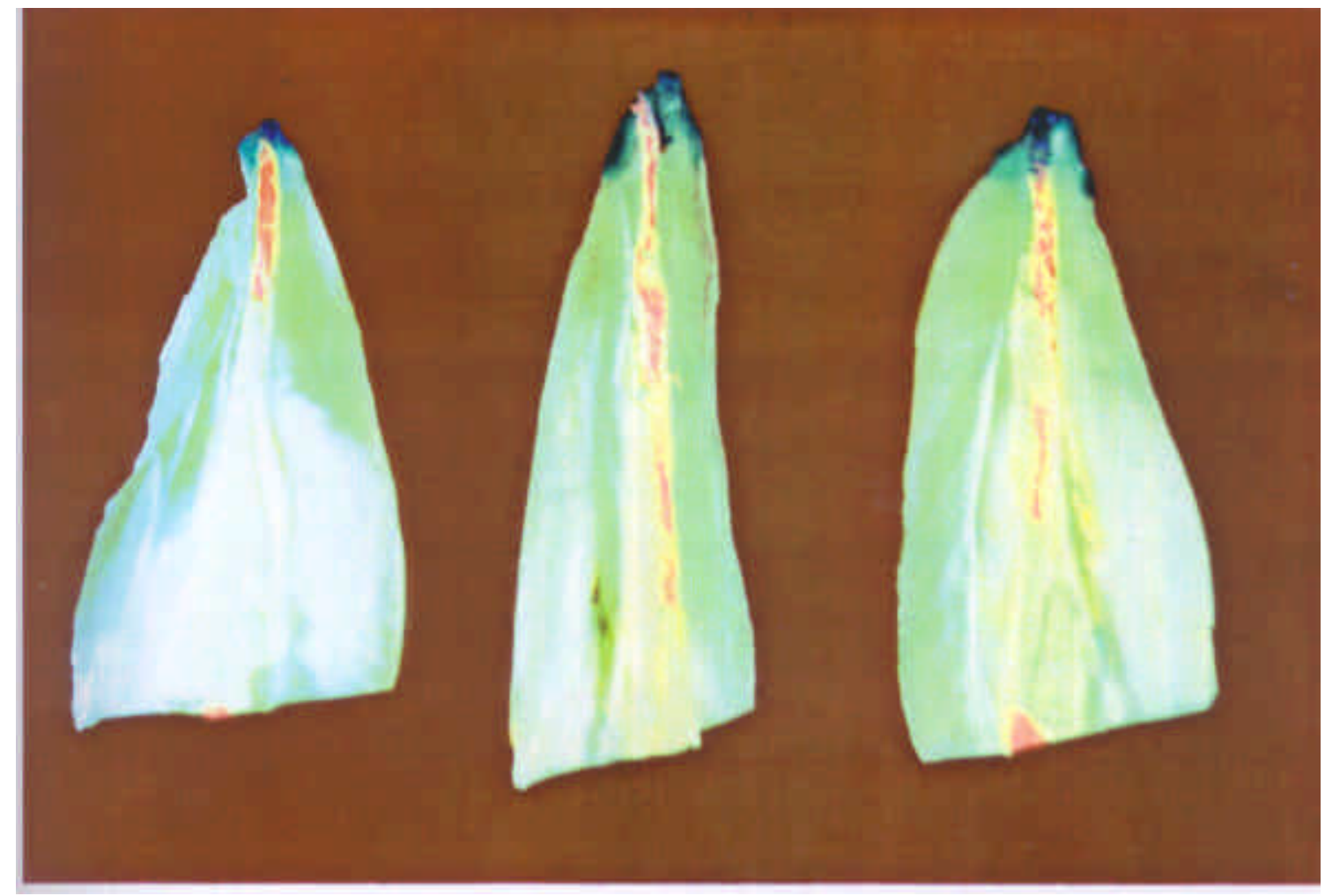

FIGURA 3 - Hemisecções com os canais obturados com o AH Plus acrescido de $5 \%$ de hidróxido de cálcio e utilizados para determinação da infiltração 


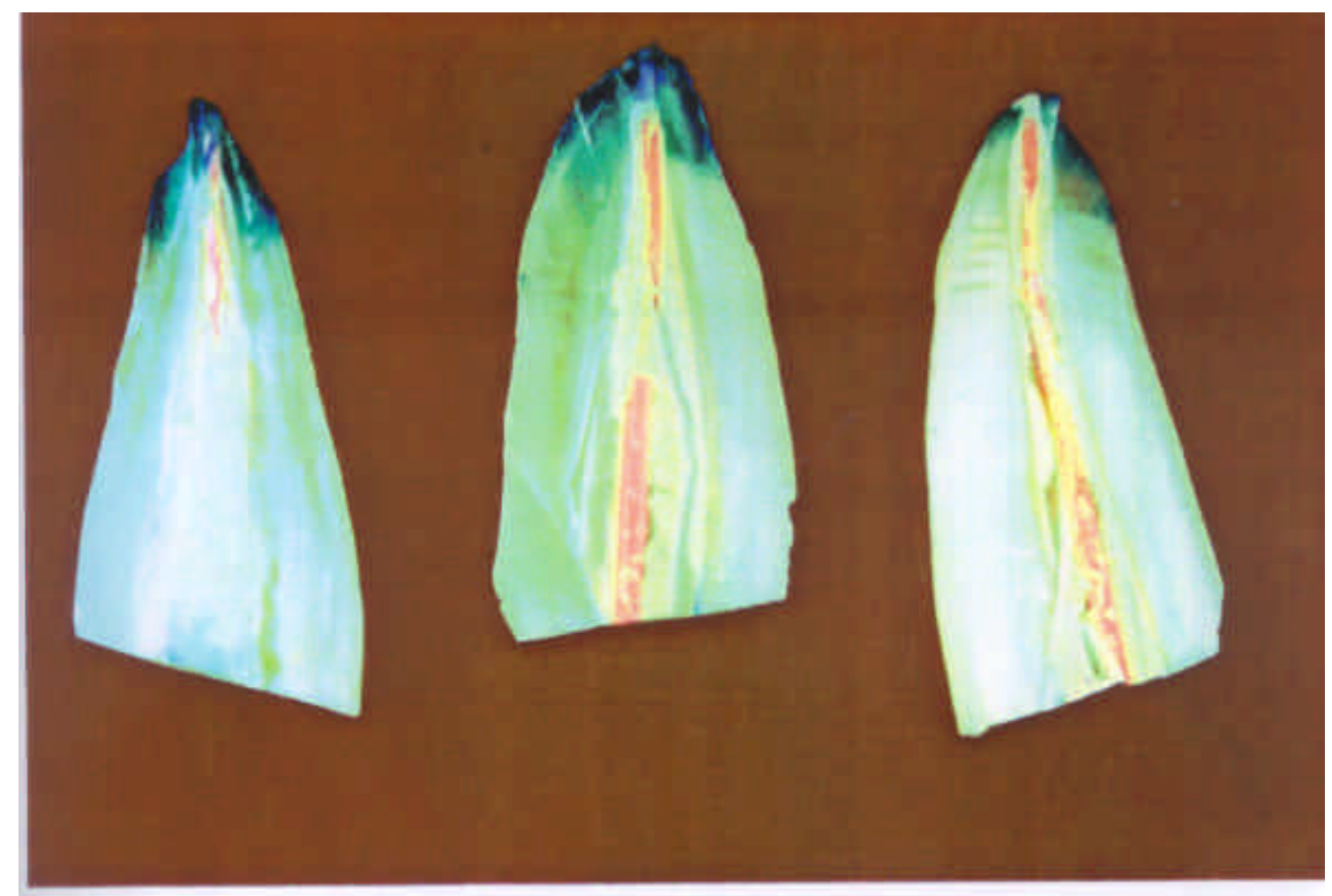

FIGURA 4 - Hemisecções com os canais obturados com o AH Plus acrescido de 10\% de hidróxido de cálcio utilizados para determinação da infiltração 


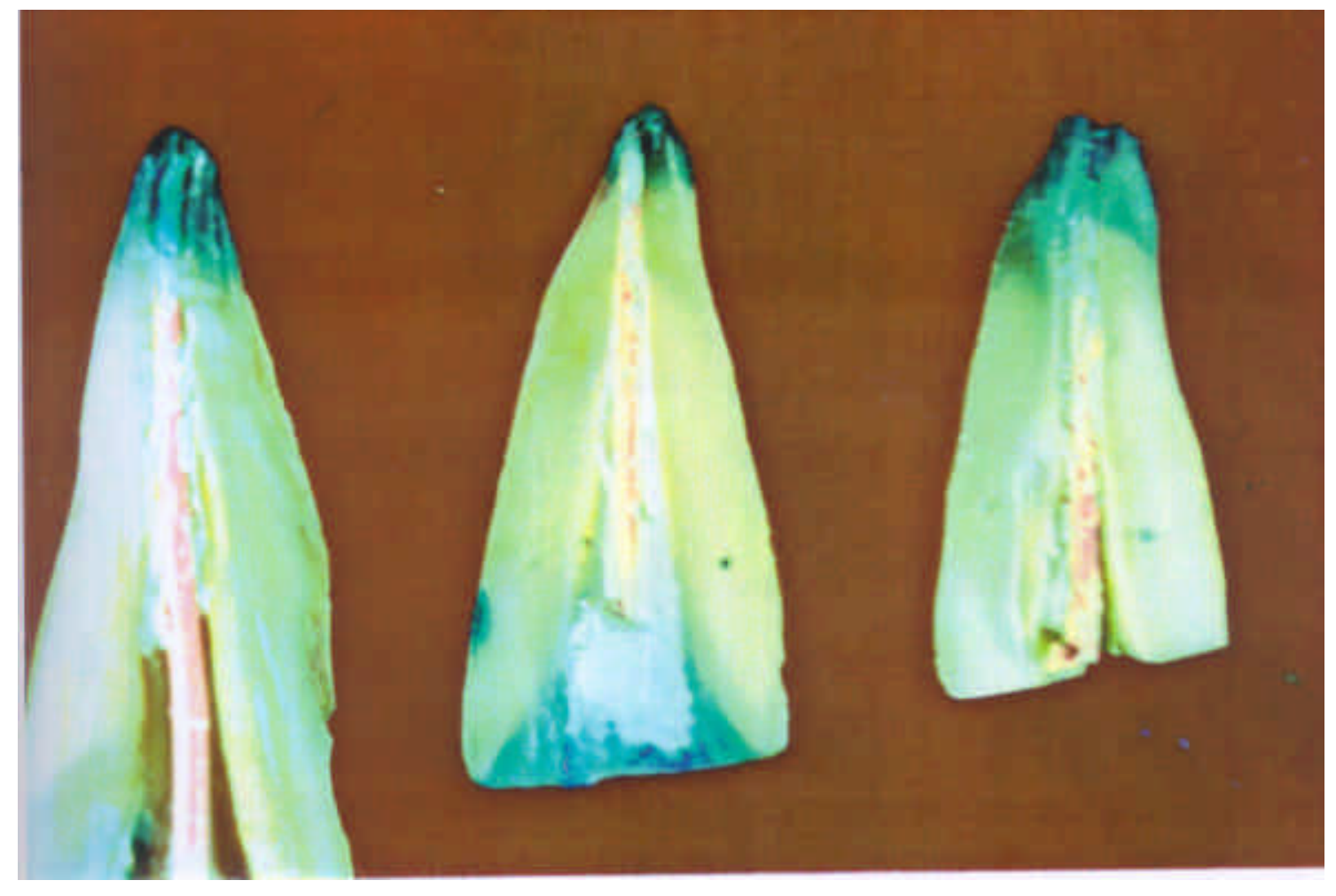

FIGURA 5 - Hemisecções com os canais obturados com o óxido de zinco e eugenol e utilizados para determinação da infiltração 


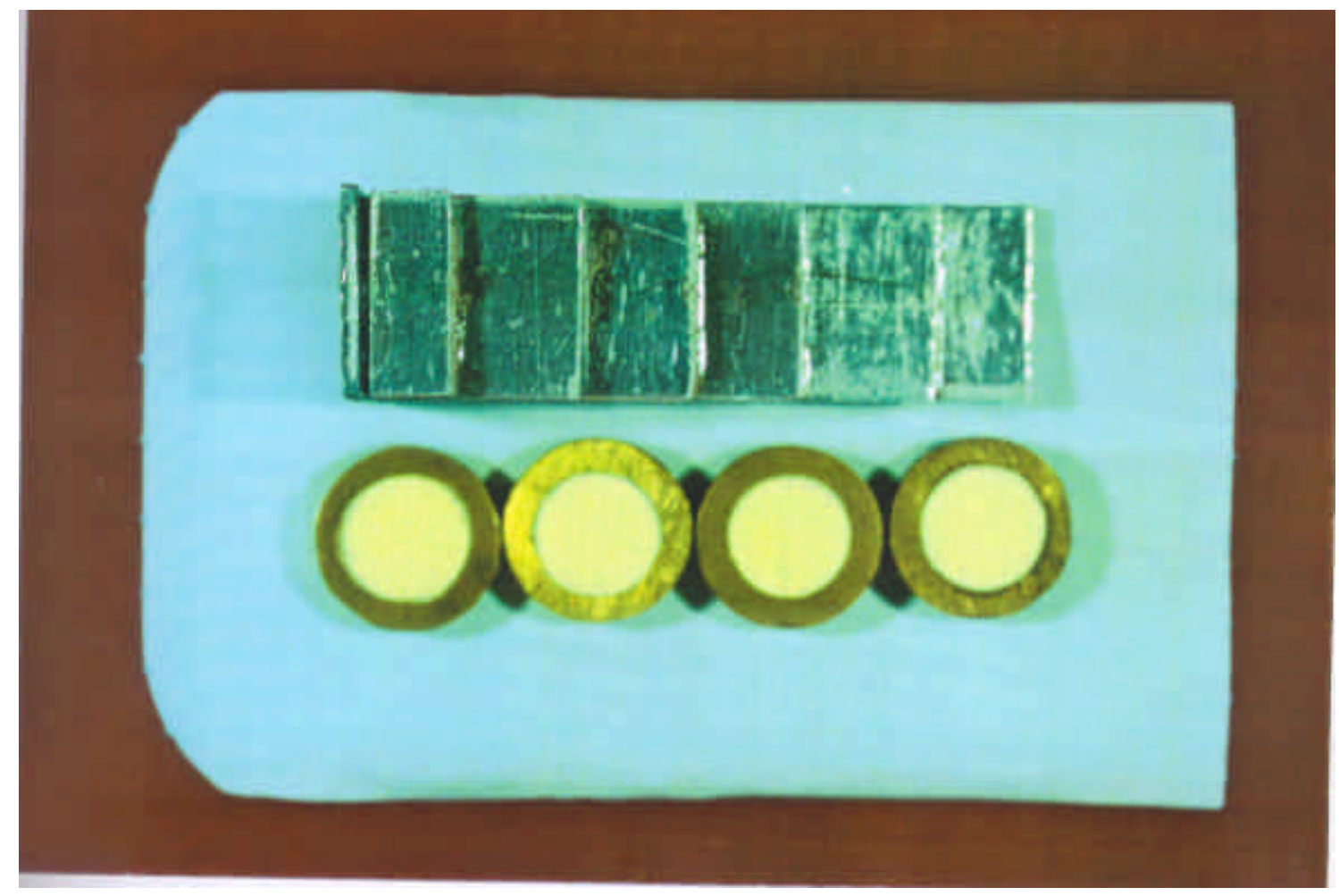

FIGURA 6 - Placa óptica com o penetrômetro e os anéis contendo materiais posicionados para tomadas radiográficas 


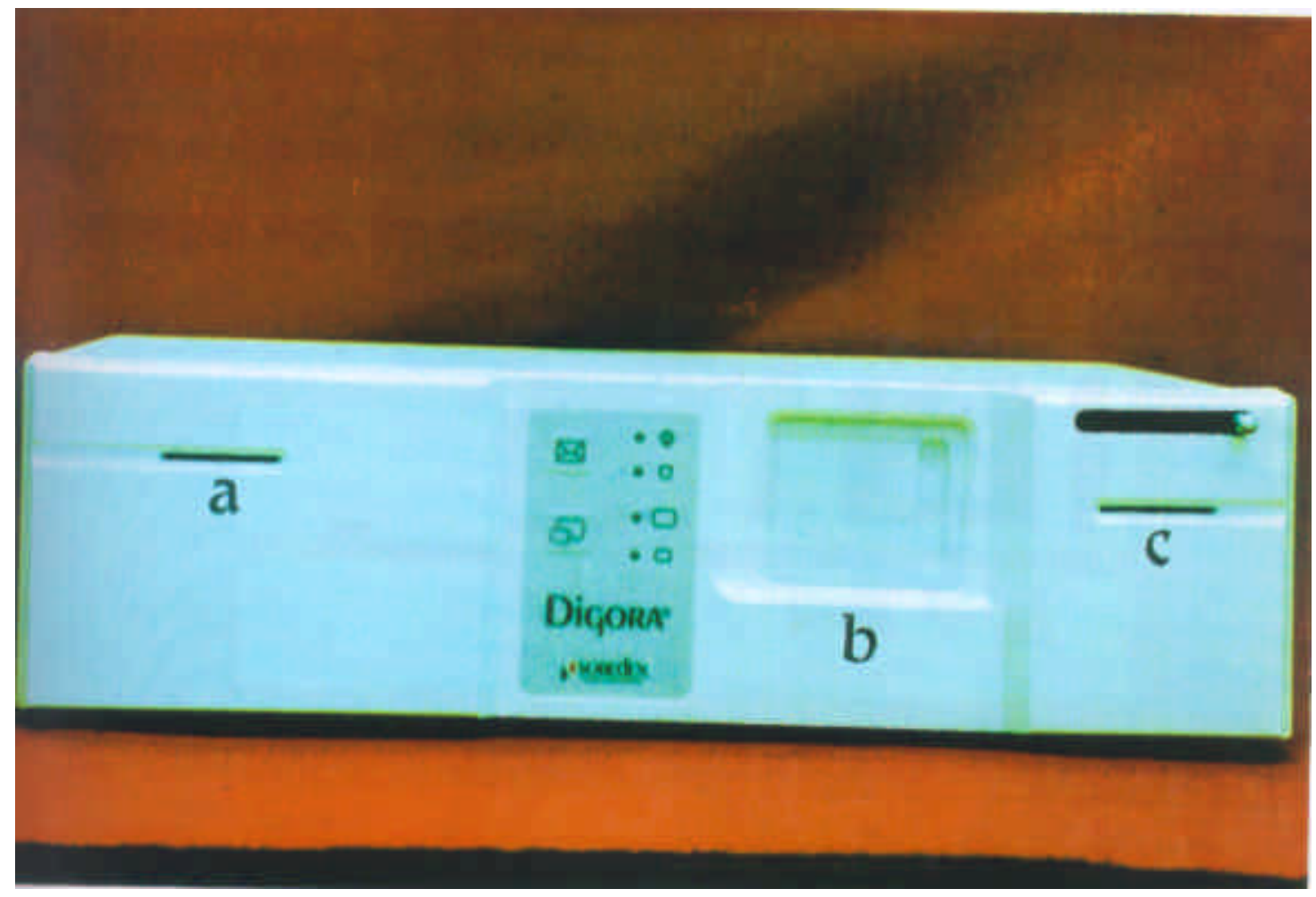

FIGURA 7 - Aparelho de imagem digital Digora empregado para determinação da radiopacidade dos materiais estudados 


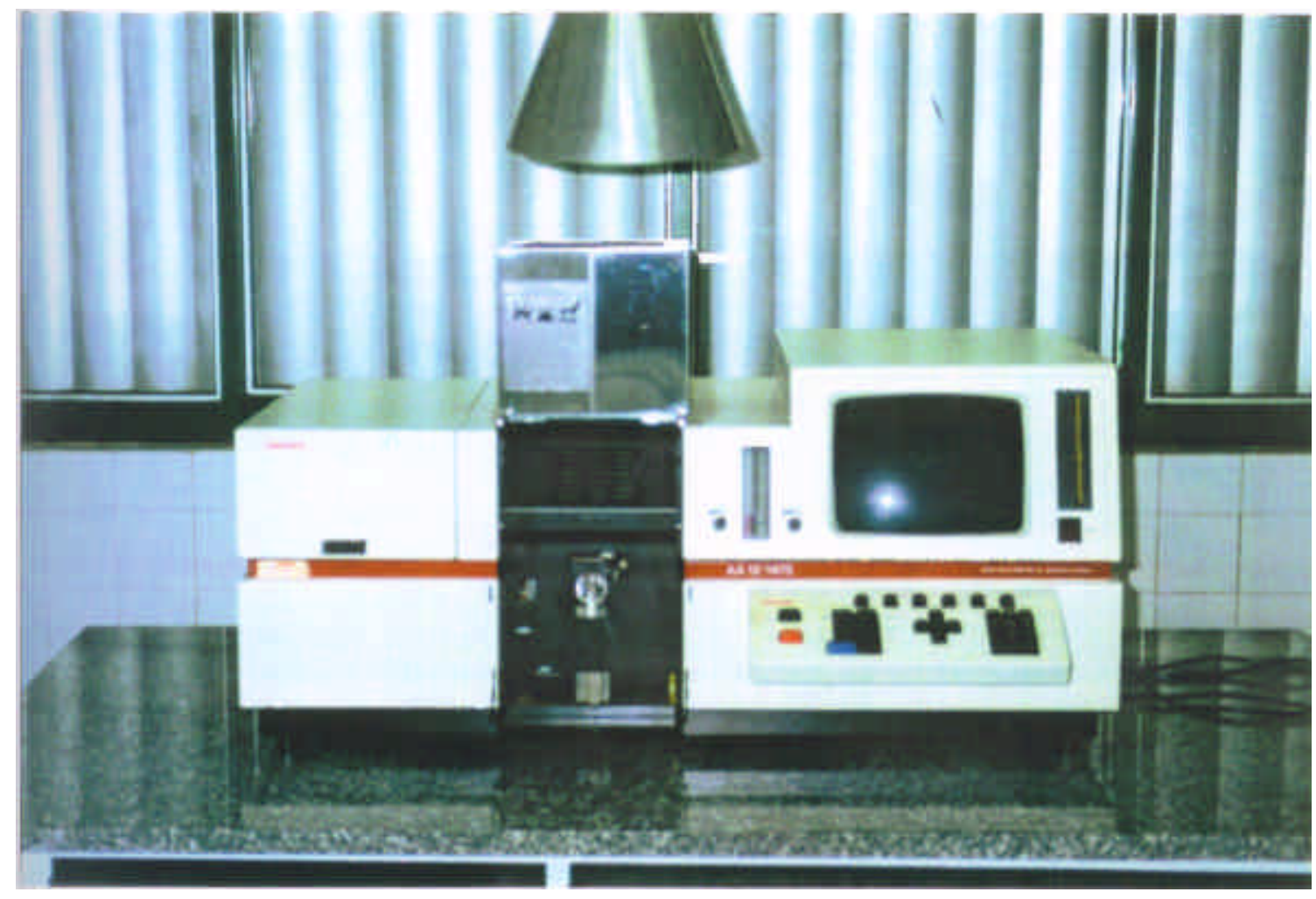

FIGURA 8 - Espectrofotômetro empregado para medição do cálcio liberado pelos materiais estudados 
5 - RESULTADOS 
$5-R \mathcal{E} \mathcal{U L T} \mathcal{A} \mathcal{D O S}$

Para melhor interpretação, os resultados foram divididos em função da propriedade analisada.

\section{1 - Tempo de presa}

$\mathrm{Na}$ Tabela 1 estão os resultados da média dos tempos de presa em minutos, medidos em ambiente seco e úmido.

\begin{tabular}{l|c|c}
\hline \multicolumn{3}{c}{ Tempo (minutos) } \\
\hline \multicolumn{1}{c}{ Ambiente } \\
\hline \multicolumn{1}{c}{ MATERIAL } & Seco & Úmido \\
\hline AH Plus + 10\% Ca $(\mathrm{OH})_{2}$ & 810 & 845 \\
\hline AH Plus + 5\% Ca(OH) $)_{2}$ & 810 & 870 \\
\hline AH Plus puro & 815 & 955 \\
\hline Óxido de zinco e eugenol & 360 & 120 \\
\hline
\end{tabular}

TABELA 1 - Tempo de presa médio, em minutos, dos materiais estudados, em função das condições ambientais

\section{2 - Escoamento}

A Tabela 2 contém as médias dos diâmetros menor e maior do teste de escoamento, bem como a média que corresponde ao escoamento.

\begin{tabular}{l|c|c|c}
\hline \multicolumn{1}{c|}{ MATERIAL } & Diâmetro menor em mm & Diâmetro maior em mm & Escoamento em mm \\
\hline AH Plus $+10 \% \mathrm{Ca}(\mathrm{OH})_{2}$ & 26.5 & 28 & 27.25 \\
\hline AH Plus $+5 \% \mathrm{Ca}(\mathrm{OH})_{2}$ & 36.5 & 37.5 & 37 \\
\hline AH Plus puro & 39.5 & 41 & 40.25 \\
\hline Óxido de zinco e eugenol & 32.5 & 33.5 & 33 \\
\hline
\end{tabular}

TABELA 2 - Diâmetros maior e menor e as médias que correspondem ao escoamento dos materiais estudados 


\section{3 - Radiopacidade}

A Tabela 3 contém as médias e desvios padrão das densidades radiográficas medidas pelo Digora e o correspondente em $\mathrm{mm}$ de alumínio dos materiais estudados. Na Figura 9 constam, graficamente, as médias da radiopacidade em $\mathrm{mm}$ de alumínio de cada grupo. Na Tabela 4 estão as comparações individuais da radiopacidade em densidade radiográfica medida pelo Digora e na Tabela 5 estão as comparações individuais entre as radiopacidades, em mm de alumínio dos materiais.

\begin{tabular}{l|c|c|c|c}
\hline \multirow{2}{*}{ Material } & \multicolumn{4}{|c}{ Radiopacidade } \\
\cline { 2 - 5 } & Densidade & Radiográfica & Milímetro de & Alumínio \\
\cline { 2 - 5 } & Média & Desvio padrão & Média & Desvio padrão \\
\hline AH Plus 10\% Ca(OH) & 240.24 & 80.46 & 6.94 & 2.32 \\
\hline AH Plus 5\% Ca(OH) & 241.03 & 80.73 & 6.95 & 2.33 \\
\hline AH Plus puro & 243.15 & 81.44 & 6.99 & 2.34 \\
\hline OZE & 212.74 & 71.25 & 6.53 & 2.18 \\
\hline Guta-percha & 230.30 & 77.14 & 6.79 & 2.27 \\
\hline Dentina terço cervical & 93.61 & 31.35 & 1.92 & 0.64 \\
\hline Dentina terço médio & 82.94 & 27.78 & 1.63 & 0.54 \\
\hline Dentina terço apical & 70.93 & 23.75 & 1.31 & 0.43 \\
\hline
\end{tabular}

TABELA 3 - Médias e desvios padrão da densidade radiográfica medida pelo Digora e do correspondente em mm de alumínio 


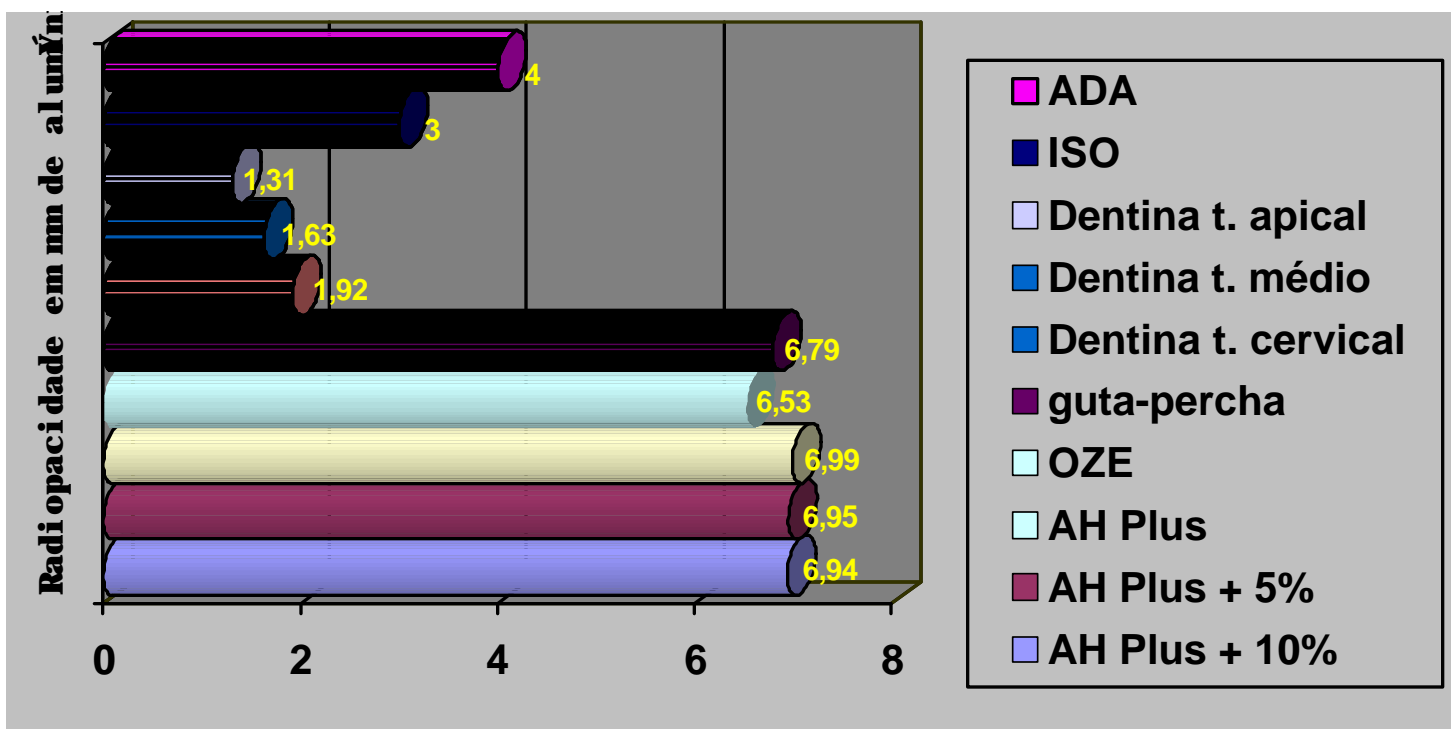

FIGURA 9 - Representação gráfica das médias da radiopacidade, em mm de alumínio 


\begin{tabular}{|c|c|c|}
\hline Comparações individuais & Diferença & Significância \\
\hline AH Plus puro $\mathrm{X}$ AH Plus $5 \% \mathrm{Ca}(\mathrm{OH})_{2}$ & 2.11 & Não significante \\
\hline AH Plus puro $\mathrm{X}$ AH Plus $10 \% \mathrm{Ca}(\mathrm{OH})_{2}$ & 2.91 & Não significante \\
\hline AH Plus puro $\mathrm{X}$ guta-percha & 12.84 & Significante \\
\hline AH Plus puro X OZE & 30.40 & Significante \\
\hline AH Plus puro $\mathrm{X}$ dentina t. cervical & 149.54 & Significante \\
\hline AH Plus puro $\mathrm{X}$ dentina t. médio & 160.21 & Significante \\
\hline AH Plus puro $\mathrm{X}$ dentina t. apical & 172.21 & Significante \\
\hline AH Plus $5 \% \mathrm{Ca}(\mathrm{OH})_{2} \mathrm{X}$ AH Plus $10 \% \mathrm{Ca}(\mathrm{OH})_{2}$ & 0.79 & Não significante \\
\hline AH Plus $5 \% \mathrm{Ca}(\mathrm{OH})_{2} \mathrm{X}$ guta-percha & 10.72 & Significante \\
\hline AH Plus $5 \% \mathrm{Ca}(\mathrm{OH})_{2} \mathrm{X} \mathrm{OZE}$ & 28.28 & Significante \\
\hline AH Plus $5 \% \mathrm{Ca}(\mathrm{OH})_{2} \mathrm{X}$ dentina t. cervical & 147.42 & Significante \\
\hline AH Plus $5 \% \mathrm{Ca}(\mathrm{OH})_{2} \mathrm{X}$ dentina t. médio & 158.09 & Significante \\
\hline AH Plus $5 \% \mathrm{Ca}(\mathrm{OH})_{2} \mathrm{X}$ dentina t. apical & 170.09 & Significante \\
\hline AH Plus $10 \% \mathrm{Ca}(\mathrm{OH})_{2} \mathrm{X}$ guta-percha & 9.93 & Significante \\
\hline AH Plus $10 \% \mathrm{Ca}(\mathrm{OH})_{2} \mathrm{X}$ OZE & 27.49 & Significante \\
\hline AH Plus $10 \% \mathrm{Ca}(\mathrm{OH})_{2} \mathrm{X}$ dentina t. cervical & 146.62 & Significante \\
\hline AH Plus $10 \% \mathrm{Ca}(\mathrm{OH})_{2} \mathrm{X}$ dentina t. médio & 157.29 & Significante \\
\hline AH Plus $10 \% \mathrm{Ca}(\mathrm{OH})_{2} \mathrm{X}$ dentina t. apical & 169.30 & Significante \\
\hline Guta-percha X OZE & 17.56 & Significante \\
\hline Guta-percha $\mathrm{X}$ dentina t. cervical & 136.69 & Significante \\
\hline Guta-percha $\mathrm{X}$ dentina t. médio & 147.36 & Significante \\
\hline Guta-percha $\mathrm{X}$ dentina t. apical & 159.37 & Significante \\
\hline OZE X dentina t. cervical & 119.13 & Significante \\
\hline OZE $X$ dentina t. médio & 129.80 & Significante \\
\hline OZE X dentina t. apical & 141.81 & Significante \\
\hline Dentina t. cervical $\mathrm{X}$ dentina t. médio & 10.67 & Significante \\
\hline Dentina t. cervical $\mathrm{X}$ dentina t. apical & 22.67 & Significante \\
\hline Dentina t. médio $\mathrm{X}$ dentina t. apical & 12.00 & Significante \\
\hline
\end{tabular}

Significante a 5\% Valor crítico: 3,54

TABELA 4 - Comparações individuais entre os grupos pelo teste de TukeyKramer, da radiopacidade, em densidade radiográfica 


\begin{tabular}{|c|c|c|}
\hline Comparações individuais & Diferença & Significância \\
\hline AH Plus puro $\mathrm{X}$ AH Plus $5 \% \mathrm{Ca}(\mathrm{OH})_{2}$ & 0.031 & Não significante \\
\hline AH Plus puro $\mathrm{X}$ AH Plus $10 \% \mathrm{Ca}(\mathrm{OH})_{2}$ & 0.041 & Não significante \\
\hline AH Plus puro X guta-percha & 0.191 & Significante \\
\hline AH Plus puro X OZE & 0.453 & Significante \\
\hline AH Plus puro $\mathrm{X}$ dentina t. cervical & 5.062 & Significante \\
\hline AH Plus puro $\mathrm{X}$ dentina t. médio & 5.353 & Significante \\
\hline AH Plus puro $\mathrm{X}$ dentina t. apical & 5.678 & Significante \\
\hline AH Plus $5 \% \mathrm{Ca}(\mathrm{OH})_{2} \mathrm{X}$ AH Plus $10 \% \mathrm{Ca}(\mathrm{OH})_{2}$ & 0.009 & Não significante \\
\hline AH Plus $5 \% \mathrm{Ca}(\mathrm{OH})_{2} \mathrm{X}$ guta-percha & 0.159 & Significante \\
\hline AH Plus $5 \% \mathrm{Ca}(\mathrm{OH})_{2} \mathrm{X} \mathrm{OZE}$ & 0.422 & Significante \\
\hline AH Plus $5 \% \mathrm{Ca}(\mathrm{OH})_{2} \mathrm{X}$ dentina t. cervical & 5.030 & Significante \\
\hline AH Plus $5 \% \mathrm{Ca}(\mathrm{OH})_{2} \mathrm{X}$ dentina t. médio & 5.322 & Significante \\
\hline AH Plus $5 \% \mathrm{Ca}(\mathrm{OH})_{2} \mathrm{X}$ dentina t. apical & 5.646 & Significante \\
\hline AH Plus $10 \% \mathrm{Ca}(\mathrm{OH})_{2} \mathrm{X}$ guta-percha & 0.150 & Significante \\
\hline AH Plus $10 \% \mathrm{Ca}(\mathrm{OH})_{2} \mathrm{X}$ OZE & 0.412 & Significante \\
\hline AH Plus $10 \% \mathrm{Ca}(\mathrm{OH})_{2} \mathrm{X}$ dentina t. cervical & 5.020 & Significante \\
\hline AH Plus $10 \% \mathrm{Ca}(\mathrm{OH})_{2} \mathrm{X}$ dentina t. médio & 5.312 & Significante \\
\hline AH Plus $10 \% \mathrm{Ca}(\mathrm{OH})_{2} \mathrm{X}$ dentina t. apical & 5.636 & Significante \\
\hline Guta-percha X OZE & 0.262 & Significante \\
\hline Guta-percha $\mathrm{X}$ dentina t. cervical & 4.870 & Significante \\
\hline Guta-percha $\mathrm{X}$ dentina t. médio & 5.162 & Significante \\
\hline Guta-percha $\mathrm{X}$ dentina t. apical & 5.486 & Significante \\
\hline OZE X dentina t. cervical & 4.608 & Significante \\
\hline OZE X dentina t. médio & 4.900 & Significante \\
\hline OZE X dentina t. apical & 5.224 & Significante \\
\hline Dentina t. cervical $\mathrm{X}$ dentina t. médio & 0.291 & Significante \\
\hline Dentina t. cervical $\mathrm{X}$ dentina t. apical & 0.616 & Significante \\
\hline Dentina t. médio $\mathrm{X}$ dentina t. apical & 0.324 & Significante \\
\hline
\end{tabular}

Significante a 5\% Valor crítico: 0,068

TABELA 5 - Comparações individuais entre os grupos, da radiopacidade em milímetro de alumínio pelo teste de Tukey-Kramer 


\section{4 - Infiltração apical}

A Tabela 6 contém as medidas da infiltração apical, em milímetros, dos materiais em estudo. Na Tabela 7 se encontra a comparação global das infiltrações entre os materiais pelo teste de Kruskal-Wallis. A Tabela 8 contém as comparações individuais da infiltração entre os grupos em estudo, pelo teste de Miller. Na Figura 10, consta a representação gráfica das médias de infiltração nos diferentes grupos.

\begin{tabular}{|c|c|c|c|c|}
\hline & AH Plus puro & AH Plus 10\% & AH Plus5\% & $\overline{\mathrm{OZE}}$ \\
\hline 1 & 2.91 & 0.48 & 0.97 & 3.40 \\
\hline 2 & 3.62 & 1.82 & 1.74 & 2.43 \\
\hline 3 & 1.74 & 1.89 & 2.16 & 1.82 \\
\hline 4 & 3.37 & 2.16 & 0.77 & 2.67 \\
\hline 5 & 3.47 & 1.23 & 1.11 & 1.94 \\
\hline 6 & 2.72 & 3.40 & 2.79 & 2.06 \\
\hline 7 & 2.30 & 2.38 & 2.16 & 1.96 \\
\hline 8 & 2.55 & 1.62 & 2.47 & 2.79 \\
\hline 9 & 2.30 & 2.91 & 1.26 & 3.32 \\
\hline 10 & 3.37 & 1.74 & 2.38 & 4.13 \\
\hline 11 & 2.89 & 2.11 & 1.99 & 2.11 \\
\hline 12 & 2.91 & 2.43 & 0.85 & 5.10 \\
\hline 13 & 3.40 & 2.38 & 1.21 & 4.86 \\
\hline 14 & 4.66 & 2.28 & 1.43 & 2.67 \\
\hline 15 & 3.64 & 1.33 & 2.38 & 2.43 \\
\hline 16 & 1.57 & 2.43 & 2.16 & 2.43 \\
\hline 17 & 2.55 & 2.96 & 1.82 & 2.72 \\
\hline 18 & 2.18 & 1.62 & 1.96 & 3.32 \\
\hline 19 & 2.43 & 0.36 & 3.08 & 2.35 \\
\hline 20 & 3.28 & 2.67 & 4.00 & 3.93 \\
\hline
\end{tabular}

TABELA 6 - Infiltração marginal apical medida em milímetros, propiciada pelos materiais em estudo 


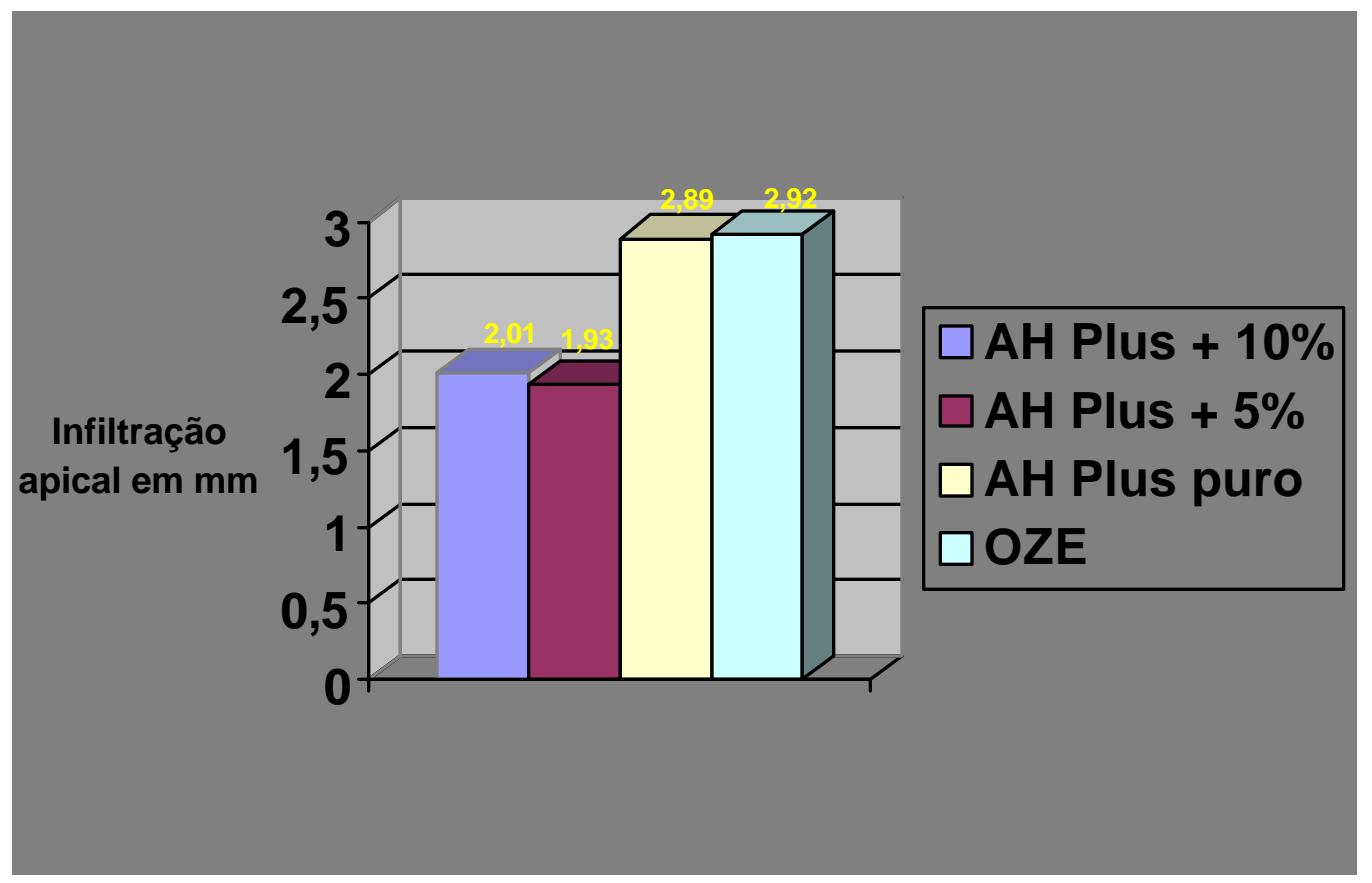

FIGURA 10 - Representação gráfica das médias das infiltrações marginais apicais, em milímetros, propiciadas pelos materiais estudados 


\begin{tabular}{l|c|c|c|c}
\hline \multicolumn{1}{c|}{ Grupo } & Soma de postos & Posto médio & Escore médio & N. valores \\
\hline AH Plus puro & 1074 & 53.7 & 2.893 & 20 \\
\hline AH Plus $10 \% \mathrm{Ca}(\mathrm{OH})_{2}$ & 608 & 30.4 & 2.01 & 20 \\
\hline AH Plus 5\% Ca(OH) 2 & 542.5 & 27.125 & 1.9345 & 20 \\
\hline OZE & 1015.5 & 50.775 & 2.922 & 20 \\
\hline
\end{tabular}

Valor crítico: $7.81 \quad \mathrm{Hc}=20.78774($ Significante para $\mathrm{p}<0,05)$

TABELA 7 - Comparação global da infiltração apical entre os grupos, pelo teste de Kruskal-Wallis

\begin{tabular}{l|c|c}
\hline \multicolumn{1}{c|}{ Comparações } & Diferença & Significância \\
\hline AH Plus puro X AH Plus 10\% Ca(OH $)_{2}$ & 23.3 & Significante \\
\hline AH Plus puro X AH Plus 5\% Ca(OH $)_{2}$ & 26.575 & Significante \\
\hline AH Plus puro X OZE & 2.925 & Não significante \\
\hline AH Plus 10\% Ca(OH $)_{2}$ X AH Plus 5\% Ca(OH $)_{2}$ & 3.275 & Não significante \\
\hline AH Plus 10\% Ca(OH $)_{2}$ X OZE & 20.375 & Significante \\
\hline AH Plus $5 \% \mathrm{Ca}(\mathrm{OH})_{2}$ X OZE & 23.65 & Significante \\
\hline
\end{tabular}

Significante para $\mathrm{p}<0,05$ Valor crítico: 18,86

TABELA 8 - Comparações individuais da infiltração apical entre os cimentos, pelo teste de Miller 


\section{5 - Análise do pH}

A Tabela 9 apresenta as médias e desvios padrão do $\mathrm{pH}$, em função do tempo. Na Figura 11 está a representação gráfica da média do $\mathrm{pH}$ em cada período, em função do material estudado. A Tabela 10 contém as comparações individuais do $\mathrm{pH}$ entre os materiais, enquanto que na Tabela 11 se encontram as comparações entre o períodos de medição do $\mathrm{pH}$, pelo teste de TuKey-Kramer. A Tabela 12 apresenta a comparação intra-grupo do pH, em função do tempo, pelo teste de Tukey-Kramer.

\begin{tabular}{l|c|c|c|c|c|c|c|c}
\hline \multirow{2}{*}{} & \multicolumn{2}{|c|}{$\begin{array}{c}\text { AH Plus 10\% de } \\
\text { Ca(OH) }\end{array}$} & \multicolumn{2}{c|}{$\begin{array}{c}\text { AH Plus 5\% de } \\
\text { Ca(OH) }\end{array}$} & \multicolumn{2}{c}{ AH Plus puro } & \multicolumn{2}{c}{ OZE } \\
\cline { 2 - 9 } & Média & Desv. pad. & Média & Desv. pad. & Média & Desv. pad. & Média & Desv. pad. \\
\hline 24 horas & 7.23 & 0.10 & 7.18 & 0.13 & 7.10 & 0.18 & 6.89 & 0.10 \\
\hline 48 horas & 7.36 & 0.17 & 7.28 & 0.09 & 7.21 & 0.17 & 7.01 & 0.03 \\
\hline 7 dias & 7.51 & 0.14 & 7.41 & 0.11 & 7.38 & 0.09 & 6.97 & 0.05 \\
\hline 14 dias & 7.98 & 0.03 & 7.94 & 0.03 & 7.43 & 0.08 & 7.15 & 0.02 \\
\hline 30 dias & 8.02 & 0.04 & 7.99 & 0.03 & 7.76 & 0.08 & 7.10 & 0.04 \\
\hline
\end{tabular}

TABELA 9 - Médias e desvios padrão do pH dos cimentos estudados nos diferentes períodos de observação 


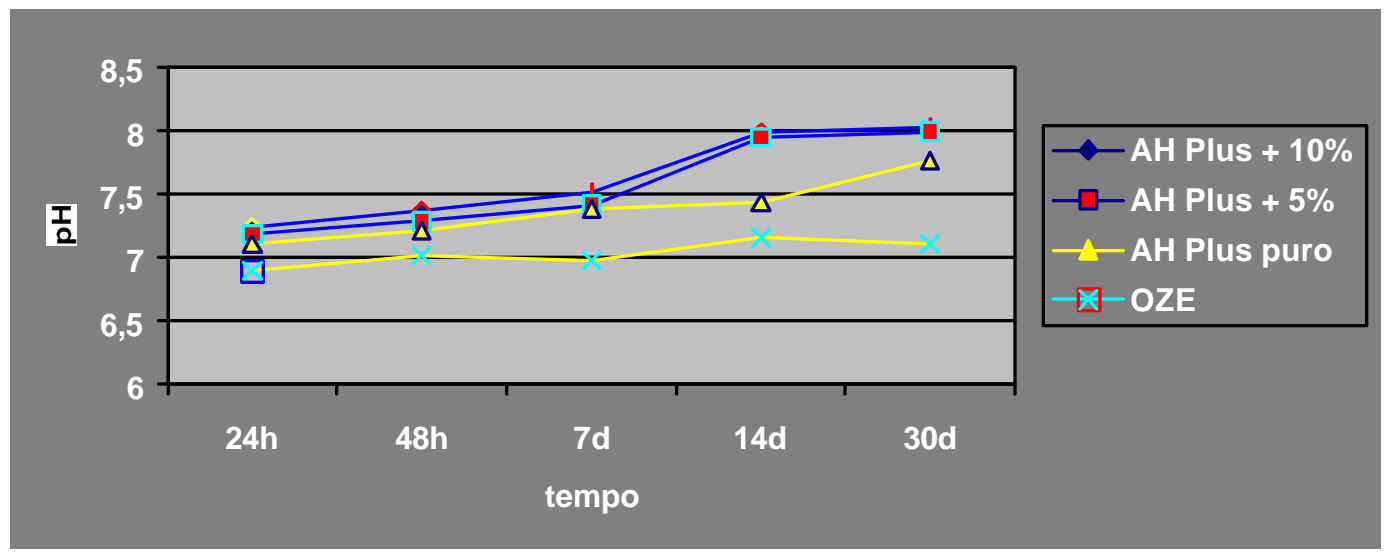

FIGURA 11 - Representação gráfica das médias do pH dos materiais estudados, em função do tempo 


\begin{tabular}{l|c|c|c|c|c}
\hline \multicolumn{1}{c|}{ Comparação } & Média & Média & Diferença & Valor crítico & Significância \\
\hline AH Plus 10\% X AH Plus 5\% & 7.62 & 7.56 & 0.06 & 0.06 & Não significante \\
\hline AH Plus 10\% X AH Plus & 7.62 & 7.37 & 0.25 & 0.06 & Significante \\
\hline AH Plus 10\% X OZE & 7.62 & 7.02 & 0.60 & 0.06 & Significante \\
\hline AH Plus 5\% X AH Plus & 7.56 & 7.37 & 0.19 & 0.06 & Significante \\
\hline AH Plus 5\% X OZE & 7.56 & 7.02 & 0.54 & 0.06 & Significante \\
\hline AH Plus X OZE & 7.37 & 7.02 & 0.35 & 0.06 & Significante \\
\hline
\end{tabular}

Significante para $\mathrm{p}<0,05$

TABELA 10 - Comparações individuais do pH dos cimentos, pelo teste de TukeyKramer

\begin{tabular}{l|c|c|c|c|c}
\hline Comparações & Média & Média & Diferença & Valor Crítico & Significância \\
\hline $24 \mathrm{~h}$ X 48h & 7.10 & 7.22 & 0.12 & 0.095 & Significante \\
\hline $24 \mathrm{~h} \mathrm{X} \mathrm{7d}$ & 7.10 & 7.32 & 0.22 & 0.095 & Significante \\
\hline $24 \mathrm{~h} \mathrm{X} \mathrm{14d}$ & 7.10 & 7.62 & 0.52 & 0.095 & Significante \\
\hline $24 \mathrm{~h} \mathrm{X} \mathrm{30d}$ & 7.10 & 7.72 & 0.62 & 0.095 & Significante \\
\hline $48 \mathrm{~h} \mathrm{X} \mathrm{7d}$ & 7.22 & 7.32 & 0.10 & 0.095 & Significante \\
\hline $48 \mathrm{~h} \mathrm{X} \mathrm{14d}$ & 7.22 & 7.62 & 0.40 & 0.095 & Significante \\
\hline $48 \mathrm{~h} \times$ 30d & 7.22 & 7.72 & 0.50 & 0.095 & Significante \\
\hline $7 \mathrm{~d}$ X 14d & 7.32 & 7.62 & 0.30 & 0.095 & Significante \\
\hline $7 \mathrm{~d}$ X 30d & 7.32 & 7.72 & 0.40 & 0.095 & Significante \\
\hline 14d X 30d & 7.62 & 7.72 & 0.10 & 0.095 & Significante \\
\hline
\end{tabular}

Significante para $p<0,05$

TABELA 11 - Comparações individuais entre os períodos de medição do pH, pelo teste de Tukey-Kramer 


\begin{tabular}{|c|c|c|}
\hline Comparações & Diferença & Significância \\
\hline AH Plus $10 \%$ 24h X AH Plus $10 \%$ 48h & 0.13 & Não Significante \\
\hline AH Plus $10 \%$ 24h X AH Plus 10\% 7d & 0.28 & Não Significante \\
\hline AH Plus $10 \%$ 24h X AH Plus $10 \%$ 14d & 0.75 & Significante \\
\hline AH Plus $10 \%$ 24h X AH Plus $10 \%$ 30d & 0.79 & Significante \\
\hline AH Plus $10 \%$ 48h X AH Plus 10\% 7d & 0.15 & Não Significante \\
\hline AH Plus $10 \%$ 48h X AH Plus $10 \%$ 14d & 0.62 & Significante \\
\hline AH Plus $10 \%$ 48h X AH Plus $10 \%$ 30d & 0.66 & Significante \\
\hline AH Plus $10 \%$ 7d X AH Plus $10 \%$ 14d & 0.47 & Não Significante \\
\hline AH Plus $10 \%$ 7d X AH Plus $10 \%$ 30d & 0.51 & Significante \\
\hline AH Plus $10 \%$ 14d X AH Plus $10 \%$ 30d & 0.04 & Não Significante \\
\hline AH Plus 5\% 24h X AH Plus 5\% 48h & 0.10 & Não Significante \\
\hline AH Plus 5\% 24h X AH Plus 5\% 7d & 0.23 & Não Significante \\
\hline AH Plus 5\% 24h X AH Plus 5\% 14d & 0.76 & Significante \\
\hline AH Plus 5\% 24h X AH Plus 5\% 30d & 0.81 & Significante \\
\hline AH Plus 5\% 48h X AH Plus 5\% 7d & 0.13 & Não Significante \\
\hline AH Plus 5\% 48h X AH Plus 5\% 14d & 0.66 & Significante \\
\hline AH Plus 5\% 48h X AH Plus 5\% 30d & 0.71 & Significante \\
\hline AH Plus 5\% 7d X AH Plus 5\% 14d & 0.53 & Significante \\
\hline AH Plus 5\% 7d X AH Plus 5\% 30d & 0.58 & Significante \\
\hline AH Plus 5\% 14d X AH Plus 5\% 30d & 0.05 & Não Significante \\
\hline AH Plus 24h X AH Plus 48h & 0.11 & Não Significante \\
\hline AH Plus 24h X AH Plus 7d & 0.28 & Não Significante \\
\hline AH Plus 24h X AH Plus 14d & 0.33 & Não Significante \\
\hline AH Plus 24h X AH Plus 30d & 0.66 & Significante \\
\hline AH Plus 48h X AH Plus 7d & 0.17 & Não Significante \\
\hline AH Plus 48h X AH Plus 14d & 0.22 & Não Significante \\
\hline AH Plus 48h X AH Plus 30d & 0.55 & Significante \\
\hline AH Plus 7d X AH Plus 14d & 0.05 & Não Significante \\
\hline AH Plus 7d X AH Plus 30d & 0.38 & Não Significante \\
\hline AH Plus 14d X AH Plus 30d & 0.33 & Não Significante \\
\hline OZE 24h X OZE 48h & 0.12 & Não Significante \\
\hline OZE 24h X OZE 7d & 0.08 & Não Significante \\
\hline OZE 24h X OZE 14d & 0.26 & Não Significante \\
\hline OZE 24h X OZE 30d & 0.21 & Não Significante \\
\hline OZE 48h X OZE 7d & 0.04 & Não Significante \\
\hline OZE 48h X OZE 14d & 0.14 & Não Significante \\
\hline OZE 48h X OZE 30d & 0.09 & Não Significante \\
\hline OZE 7d X OZE 14d & 0.18 & Não Significante \\
\hline OZE 7d X OZE 30d & 0.13 & Não Significante \\
\hline OZE 14d X OZE 30d & 0.05 & Não Significante \\
\hline
\end{tabular}

TABELA 12 - Comparações individuais intra-grupos do $\mathrm{pH}$ para verificar a interação tempo/cimento, pelo teste de Tukey-Kramer 


\section{6 - Análise da liberação de cálcio}

A Tabela 13 apresenta as médias e desvios padrão da liberação de cálcio dos cimentos em estudo. Na Figura 12 está a representação gráfica da média da liberação de cálcio em função do tempo, de cada grupo. A Tabela 14 contém as comparações individuais, entre os grupos, da medição da liberação de cálcio; enquanto que a Tabela 15 apresenta as comparações entre os períodos de medição. A Tabela 16 contém as comparações intra-grupos da liberação de cálcio, demonstrando a interação material-tempo.

\begin{tabular}{l|c|c|c|c|c|c|c|c}
\hline & \multicolumn{2}{|c|}{ AH Plus 10\% de Ca(OH) } & \multicolumn{2}{c|}{$\begin{array}{c}\text { AH Plus 5\% de } \\
\text { Ca(OH) }\end{array}$} & \multicolumn{2}{c}{ AH Plus puro } & \multicolumn{2}{c}{ OZE } \\
\hline & Média & Desv. pad. & Média & Desv. pad. & Média & Desv. pad. & Média & Desv. pad. \\
\hline 24 horas & 0.16 & 0.01 & 0.13 & 0.02 & 0.10 & 0.01 & 0.09 & 0.005 \\
\hline 48 horas & 0.18 & 0.01 & 0.13 & 0.02 & 0.10 & 0.008 & 0.09 & 0 \\
\hline 7 dias & 0.21 & 0.01 & 0.14 & 0.01 & 0.10 & 0.007 & 0.09 & 0.003 \\
\hline 14 dias & 0.39 & 0.02 & 0.26 & 0.01 & 0.11 & 0.01 & 0.10 & 0 \\
\hline 30 dias & 0.46 & 0.02 & 0.35 & 0.03 & 0.11 & 0.01 & 0.10 & 0 \\
\hline
\end{tabular}

TABELA 13 - Médias e desvios padrão da liberação de cálcio em mg\% dos cimentos estudados, nos diferentes períodos de observação 


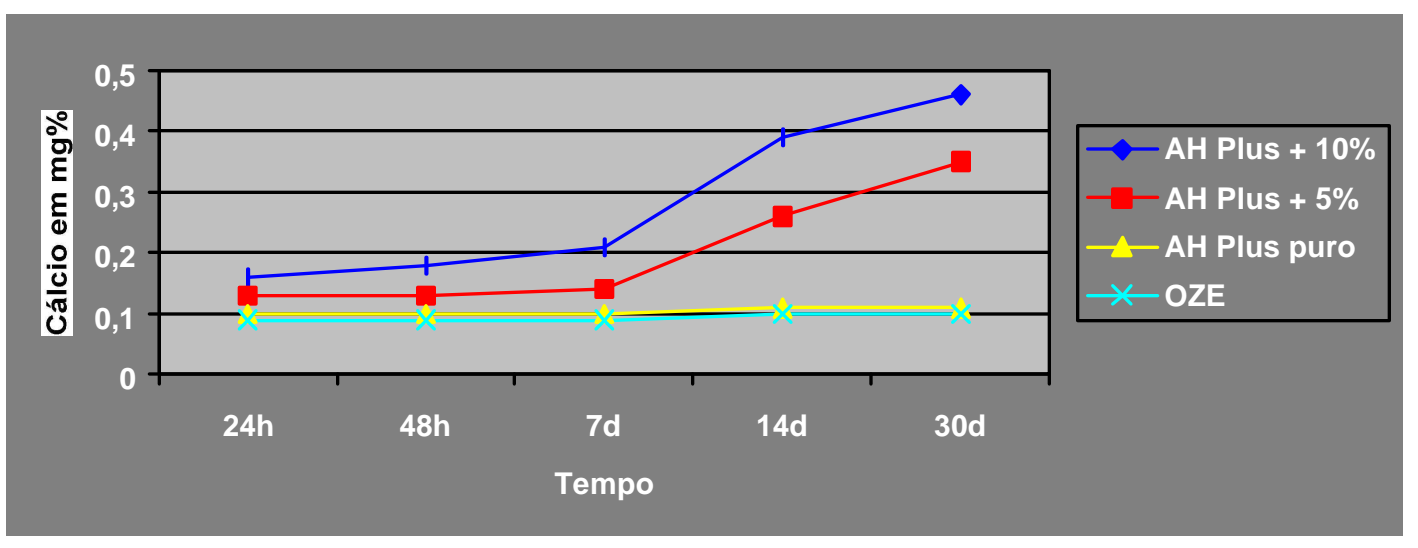

FIGURA 12 - Representação gráfica das médias da liberação de cálcio dos materiais estudados, em função do tempo 


\begin{tabular}{l|c|c|c|c|c}
\hline \multicolumn{1}{c|}{ Comparação } & Média & Média & Diferença & Valor crítico & Significância \\
\hline AH Plus 10\% X AH Plus 5\% & 0.28 & 0.20 & 0.08 & 0.01 & Significante \\
\hline AH Plus 10\% X AH Plus & 0.28 & 0.11 & 0.17 & 0.01 & Significante \\
\hline AH Plus 10\% X OZE & 0.28 & 0.09 & 0.19 & 0.01 & Significante \\
\hline AH Plus 5\% X AH Plus & 0.20 & 0.11 & 0.09 & 0.01 & Significante \\
\hline AH Plus 5\% X OZE & 0.20 & 0.09 & 0.11 & 0.01 & Significante \\
\hline AH Plus X OZE & 0.11 & 0.09 & 0.02 & 0.01 & Significante \\
\hline
\end{tabular}

Significante para $\mathrm{p}<0,05$

TABELA 14 - Comparações individuais da liberação de cálcio dos cimentos, pelo teste de Tukey-Kramer

\begin{tabular}{c|c|c|c|c|c}
\hline Comparações & Média & Média & Diferença & Valor Crítico & Significância \\
\hline $24 \mathrm{~h} \times 48 \mathrm{~h}$ & 0.12 & 0.12 & 0 & 0.01 & Não significante \\
\hline $24 \mathrm{~h} \mathrm{X} \mathrm{7d}$ & 0.12 & 0.13 & 0.01 & 0.01 & Não significante \\
\hline $24 \mathrm{~h} \times 14 \mathrm{~d}$ & 0.12 & 0.22 & 0.10 & 0.01 & Significante \\
\hline $24 \mathrm{~h} \mathrm{X} \mathrm{30d}$ & 0.12 & 0.26 & 0.14 & 0.01 & Significante \\
\hline $48 \mathrm{~h} \mathrm{X} \mathrm{7d}$ & 0.12 & 0.13 & 0.01 & 0.01 & Não significante \\
\hline $48 \mathrm{~h} \mathrm{X} \mathrm{14d}$ & 0.12 & 0.22 & 0.10 & 0.01 & Significante \\
\hline $48 \mathrm{~h} \mathrm{X} \mathrm{30d}$ & 0.12 & 0.26 & 0.14 & 0.01 & Significante \\
\hline $7 \mathrm{~d} \times 14 \mathrm{~d}$ & 0.13 & 0.22 & 0.09 & 0.01 & Significante \\
\hline $7 \mathrm{~d} \times 30 \mathrm{~d}$ & 0.13 & 0.26 & 0.13 & 0.01 & Significante \\
\hline 14d X 30d & 0.22 & 0.26 & 0.04 & 0.01 & Significante \\
\hline
\end{tabular}

Significante para $\mathrm{p}<0,05$

TABELA 15 - Comparações individuais entre os períodos de medição da liberação de cálcio, pelo teste de Tukey-Kramer 


\begin{tabular}{|c|c|c|}
\hline Comparações & Diferença & Significância \\
\hline AH Plus $10 \%$ 24h X AH Plus $10 \%$ 48h & 0.02 & Não Significante \\
\hline AH Plus $10 \%$ 24h X AH Plus $10 \%$ 7d & 0.05 & Não Significante \\
\hline AH Plus $10 \%$ 24h X AH Plus $10 \%$ 14d & 0.23 & Significante \\
\hline AH Plus $10 \%$ 24h X AH Plus $10 \%$ 30d & 0.30 & Significante \\
\hline AH Plus $10 \%$ 48h X AH Plus $10 \%$ 7d & 0.03 & Não Significante \\
\hline AH Plus $10 \%$ 48h X AH Plus $10 \%$ 14d & 0.21 & Significante \\
\hline AH Plus $10 \%$ 48h X AH Plus $10 \%$ 30d & 0.28 & Significante \\
\hline AH Plus $10 \%$ 7d X AH Plus 10\% 14d & 0.18 & Significante \\
\hline AH Plus $10 \%$ 7d X AH Plus $10 \%$ 30d & 0.25 & Significante \\
\hline AH Plus $10 \%$ 14d X AH Plus $10 \%$ 30d & 0.13 & Significante \\
\hline AH Plus 5\% 24h X AH Plus 5\% 48h & 0 & Não Significante \\
\hline AH Plus 5\% 24h X AH Plus 5\% 7d & 0.01 & Não Significante \\
\hline AH Plus 5\% 24h X AH Plus 5\% 14d & 0.13 & Significante \\
\hline AH Plus 5\% 24h X AH Plus 5\% 30d & 0.22 & Significante \\
\hline AH Plus 5\% 48h X AH Plus 5\% 7d & 0.01 & Não significante \\
\hline AH Plus 5\% 48h X AH Plus 5\% 14d & 0.13 & Significante \\
\hline AH Plus 5\% 48h X AH Plus 5\% 30d & 0.22 & Significante \\
\hline AH Plus 5\% 7d X AH Plus 5\% 14d & 0.12 & Significante \\
\hline AH Plus 5\% 7d X AH Plus 5\% 30d & 0.21 & Significante \\
\hline AH Plus 5\% 14d X AH Plus 5\% 30d & 0.09 & Significante \\
\hline AH Plus 24h X AH Plus 48h & 0 & Não Significante \\
\hline AH Plus 24h X AH Plus 7d & 0 & Não Significante \\
\hline AH Plus 24h X AH Plus 14d & 0.01 & Não Significante \\
\hline AH Plus 24h X AH Plus 30d & 0.01 & Não Significante \\
\hline AH Plus 48h X AH Plus 7d & 0 & Não Significante \\
\hline AH Plus 48h X AH Plus 14d & 0.01 & Não Significante \\
\hline AH Plus 48h X AH Plus 30d & 0.01 & Não significante \\
\hline AH Plus 7d X AH Plus 14d & 0.01 & Não significante \\
\hline AH Plus 7d X AH Plus 30d & 0.01 & Não significante \\
\hline AH Plus 14d X AH Plus 30d & 0 & Não significante \\
\hline OZE 24h X OZE 48h & 0 & Não significante \\
\hline OZE 24h X OZE 7d & 0 & Não significante \\
\hline OZE 24h X OZE 14d & 0.01 & Não significante \\
\hline OZE 24h X OZE 30d & 0.01 & Não significante \\
\hline OZE 48h X OZE 7d & 0 & Não significante \\
\hline OZE 48h X OZE 14d & 0.01 & Não significante \\
\hline OZE 48h X OZE 30d & 0.01 & Não significante \\
\hline OZE 7d X OZE 14d & 0.01 & Não significante \\
\hline OZE 7d X OZE 30d & 0.01 & Não significante \\
\hline OZE 14d X OZE 30d & 0 & Não significante \\
\hline
\end{tabular}

Significante para $\mathrm{p}<0,05 \quad$ Valor crítico: 0,07

TABELA 16 - Comparações individuais intra-grupos, da liberação de cálcio, para verificar a interação tempo/cimento, pelo teste de Tukey-Kramer 
6 - DISCUSSÃO 


\section{6 - $\mathcal{D} I S \operatorname{ULS} \mathcal{A} O$}

\section{1 - Das metodologias empregadas}

O presente trabalho teve por objetivo avaliar várias características físico-químicas do material AH Plus puro e acrescido de hidróxido de cálcio. As propriedades avaliadas foram a radiopacidade, tempo de presa, escoamento, $\mathrm{pH}$, liberação de cálcio e infiltração apical de corante. Assim, foram utilizadas metodologias distintas.

Para avaliação da radiopacidade, os materiais devem ser colocados em anéis metálicos com diâmetro e altura padronizadas. A ISO ${ }^{68}$ estipula que o anel deve possuir $10 \mathrm{~mm}$ de diâmetro interno e $1 \mathrm{~mm}$ de altura. Essa metodologia foi empregada por TORABINEJAD et al. ${ }^{140}$ e SHAH et al. ${ }^{124}$ para determinação da radiopacidade de materiais obturadores retrógrados. KATZ et al. ${ }^{73}$ empregaram a mesma metodologia para avaliação da radiopacidade de guta-perchas, enquanto que BEYER-OLSEN; ORSTAVIK ${ }^{19}$ testaram cimentos endodônticos. HIGGINBOTHAN ${ }^{58}$ utilizou anéis com $1,1 \mathrm{~mm}$ de altura para determinação da radiopacidade de materiais obturadores. Alguns autores ( BOSCOLO; BENATTI; GONÇALVES $^{23}$, ZYTKIEVITZ; LIMA; SOBRINHO ${ }^{156}$ ) empregaram anéis com $3 \mathrm{~mm}$ de altura. Já PETRY et al. ${ }^{109}$ utilizaram tubos plásticos para o acondicionamento dos cimentos, ao invés de anéis metálicos. Já RAY;SELTZER ${ }^{114}$ realizaram a determinação da radiopacidade empregando o próprio dente no qual obturaram o canal e, posteriormente, avaliaram visualmente, não determinando quantitativamente, dificultando, portanto, uma melhor comparação entre os materiais. Um outro fator a se salientar, é que há dentina interpondo o material e o dente e essa pode possuir diferentes espessuras, o que pode ser uma fonte de variação que influenciaria os resultados. Apesar desse método se aproximar mais da realidade clínica, acreditamos que não seja viável para esse tipo de comparação. Em nosso trabalho empregamos anéis contendo $10 \mathrm{~mm}$ de diâmetro e $2 \mathrm{~mm}$ de altura, que consiste em uma modificação da norma $n^{\circ}-8$ da $\operatorname{ADA}^{99}$ e, 
hoje corresponde a norma $\mathrm{n}^{\circ} 57$ da $\mathrm{ADA}^{9}$, que é a proposta para materiais obturadores de canais radiculares. Essa metodologia também foi utilizada por McCOMB;SMITH ${ }^{89}$ e ALMEIDA; ANTONIO; MOURA ${ }^{7}$ para determinação da radiopacidade de materiais obturadores, por MORAES ${ }^{99}$ para averiguação de materiais obturadores com resina epóxica na composição, por KAFFE et al. ${ }^{71}$ que testaram as características radiopacas de guta-percha, e ALAÇAM; GÖRGÜL; ÖMÜRLÜ3 ${ }^{3}$ que avaliaram a radiopacidade de materiais de contrastes utilizados em pastas de hidróxido de cálcio.

Como se pode observar, as metodologias variam quanto àmaneira de acondicionamento do material a ser testado, inclusive a normatização proposta pela $1 \mathrm{SO}^{68}$ é diferente da preconizada pela $A D A^{9}$, visto que a primeira propõe $1 \mathrm{~mm}$ de altura para o anel, e a segunda estipula 2mm. ORFALY; LILLEY; MOLOKHIA ${ }^{105}$ comparando a radiopacidade utilizando anéis com duas espessuras diferentes, encontraram diferenças significantes nos valores de um mesmo material, devendo portanto verificar a metodologia na hora de comparar o resultado obtido por outros autores.

Outra variável que pode ocorrer diz respeito ao aparelho de raios $X$ empregado. A norma da $\mathrm{ISO}^{68}$ e da $\mathrm{ADA}^{9}$ estipulam que o aparelho deva possuir uma Kilovoltagem entre $60 \mathrm{kV}$ e $70 \mathrm{kV}$, com 10 miliamperes e uma distância foco filme de $40 \mathrm{~cm}$. MORAES ${ }^{99}$ testou a radiopacidade de cimentos epóxicos empregando aparelhos com quilovoltagens diferentes (50,60 e $90 \mathrm{kV})$ e verificou que os valores não se diferiram significantemente. Em nosso trabalho utilizamos um aparelho de $60 \mathrm{kV}$, com 10 miliamperes e distância foco filme de $40 \mathrm{~cm}$.

Quanto ao filme a ser empregado, esse pode ser do grupo $D$ ou $E, e$ apesar dos do grupo $D$ possuírem grânulos menores e mais próximos um dos outros, oferecendo melhor qualidade de imagem, não difere nos valores da radiopacidade de materiais quando comparado com os do grupo $\mathrm{E}$, conforme já constatado na literatura (KATZ et al. ${ }^{73}$ ).

No presente trabalho não foi utilizado filme e sim uma placa ótica que era sensibilizada pelos raios $\mathrm{X}$ e, então, scaneada posteriormente pelo aparelho Digora e, posteriormente, jogado para o programa Digora 1.0, que consiste de um 
sistema de imagem digital. Semelhante metodologia foi utilizada por PETRY et al. ${ }^{109}$. Apesar desse método de análise fugir das normas propostas pela $150^{68} \mathrm{e}$ $A D A^{9}$, ele se mostrou vantajoso, visto que a obtenção da imagem é mais rápida e elimina fatores como processamento radiográfico que podem interferir na qualidade final de uma radiografia, pois pode ser influenciado pelas características do revelador e fixador, bem como pelo tempo e temperatura.

Normalmente, eram utilizadas três unidades para medição da radiopacidade de uma película ou imagem radiográfica: a transparência, ou transmitância, a opacidade e a densidade ótica. A transparência é a relação entre a luz que consegue atravessar a prata depositada na película (luz transmitida) e a luz que nela incide (luz incidente). Se, por exemplo, a luz transmitida é de 1/10 da luz incidente, diz-se que a transparência é 1/10. A opacidade é, por definição, a recíproca (o inverso) da transparência. Se a transparência é de $1 / 10$, a opacidade é 10. A densidade ótica é definida como o logaritmo decimal da opacidade $\left(\right.$ MORAES $\left.{ }^{99}\right)$. Então, para obtenção dos resultados, quando se utiliza filmes radiográficos, os valores podem ser determinados em densidade ótica, isto é feito com auxílio de fotodensitômetro ${ }^{3,19,99}$, que mede a quantidade de luz necessária para ultrapassar a imagem. Quando o material é radiopaco, pouca luz é necessária, enquanto que materiais radiolúcidos necessitam de uma maior quantidade de luz, portanto, nos resultados, quanto maior o valor registrado pelo fotodensitômetro, ou seja quanto maior a densidade ótica, mais radiolúcido é o material testado.

$\mathrm{Na}$ determinação da radiopacidade pelo sistema digital, de utilização bastante recente, ocorre a quantificação das várias tonalidades de cinza, oscilando desde o preto até o branco, em um total de 256 tons de cinza. Com isso se determinará a densidade radiográfica, e nesse caso quanto maior o valor registrado pelo aparelho mais radiopaco será o material, sendo o inverso do que ocorre quando se analisa as medidas oferecidas pelo fotodensitômetro, em densidade ótica. PETRY et al. ${ }^{109}$ denominaram erroneamente os valores obtidos de densidade ótica, pois pelo o sistema digital os valores obtidos são densidades radiográficas, conforme enfatizado por COCLETI ${ }^{29}$. 
Em 1961, MANSON-HING ${ }^{93}$ verificou que a radiopacidade do alumínio se assemelhava àda dentina e ELIASSON; HAASKEN ${ }^{36}$ propuseram que os valores obtidos em densidades óticas fossem convertidos em $\mathrm{mm}$ de alumínio, colocando uma escala de alumínio, denominada de penetrômetro na parte superior do filme. Com isso, hoje tanto a $\mathrm{ISO}^{68} \mathrm{como}$ a $\mathrm{ADA}^{9}$ estipulam os valores mínimos de radiopacidade de um material em $\mathrm{mm}$ de alumínio. Em nosso trabalho, apesar de termos utilizado o sistema digital, os valores da densidade radiográfica também foram convertidos em $\mathrm{mm}$ de alumínio, na intenção de comparar com o valor mínimo exigido pela $\mathrm{ISO}^{68}$ e pela $\mathrm{ADA}^{9}$ para materiais obturadores de canais radiculares.

Outra propriedade testada foi o escoamento que vem ditar a facilidade de manipulação e inserção do material no interior do canal radicular, bem como sua adaptação nas irregularidades da suas paredes. Métodos diferentes têm sido propostos para averiguação dessa propriedade. WEISMAN ${ }^{145}$, em 1970, utilizou pipetas com $336 \mathrm{~mm}$ de altura e $0,19 \mathrm{~mm}$ de diâmetro e volume de $0,001 \mathrm{~mL}$, simulando um canal constrito, que foram conectadas àvertical de um $T$ de vidro por meio de uma borracha, aplicando-se vácuo em uma das horizontais e o dedo na outra. A pipeta era encaixada na borracha e colocada em contato com 0 cimento espatulado, e com a aplicação do vácuo o cimento escorria para a pipeta, determinando o quanto o cimento entrou na pipeta. Este era considerado o valor do escoamento. Esse método, apesar de procurar simular as condições clinicas, apresenta a desvantagem de requerer equipamentos especiais ̀̀ vezes, difíceis de serem encontrados, sendo também difícil de ser executado. GROSSMAN ${ }^{56}$, em 1976 propôs um método em que colocava gotas dos cimentos sobre uma placa de vidro polida e limpa e, então, posicionava a placa verticalmente e após 24 horas media em $\mathrm{cm}$ a extensão do fluxo. Tal metodologia também foi empregada por ONO; MATSUMOTO ${ }^{104}$. Já SAMPAIO; SATO ${ }^{117}$ e BIRMAN et al. ${ }^{21}$ realizaram pequena modificação, colocando uma folha de papel milimetrada entre duas placas, sendo, portanto, placas duplas, e o objetivo do papel milimetrado foi facilitar a leitura. As placas também eram mantidas em posição vertical a $37^{\circ} \mathrm{C}$ por 24 horas. Esse método tem a desvantagem do tempo requerido, e também que o 
escoamento fica por conta apenas da gravidade, o que dificulta a interpretação do escoamento de alguns materiais. Em nosso trabalho empregamos a metodologia proposta pela $\mathrm{ISO}^{68}$ e $\mathrm{ADA}^{9}$, que são similares, diferindo apenas nas dimensões das placas que devem ser de $40 \times 40 \mathrm{~mm}$ para $1 S O^{68}$ e de $30 \times 30 \mathrm{~mm}$ para ADA $^{9}$, em nossos trabalho as placas apresentavam dimensões de $100 \times 100 \mathrm{~mm} \mathrm{O}$ método consiste, portanto, no emprego de duas placas de vidro lisas e sobre uma delas coloca-se $0,5 \mathrm{~mL}$ de cimento e depois posiciona a outra placa com um peso sobre o cimento. O peso que é colocado sobre o peso quando somado ao dela, deve possuir o valor de 120 gramas. Este pese deve ser mantido por um tempo de 10 minutos e, então, mede-se o maior e menor diâmetro. A média dos dois consiste no valor do escoamento. Essa metodologia foi utilizada por vários autores (McCOMB; SMITH ${ }^{89}$, MORAES ${ }^{99}$, SAVIOLI; SILVA; PÉCORA ${ }^{119}$ ). Já BENATTI; STOLF; RUHNKE ${ }^{17}$ e ZYTKIEVITZ; LIMA; SOBRINHO ${ }^{156}$ utilizaram a mesma quantidade de cimento, porém empregaram dois pesos diferentes; além do de 120 gramas proposto pelas normas, utilizaram também o peso de 520 gramas. Consideramos que o uso desse último peso é exagerado e desnecessário, além de não ser proposto pela $1 S O^{68}$ ou $\mathrm{ADA}^{9}$. Quando comparando a metodologia proposta pela $\mathrm{ISO}^{68}$ e $\mathrm{ADA}^{9}$ com aquela proposta por GROSSMAN ${ }^{56}$, ONO; MATSUMOTO ${ }^{104}$ obtiveram resultados discordantes. Apesar desses autores ${ }^{104}$ terem medido o escoamento após 1 minuto, 5 minutos e 10 minutos e não por 24 horas como proposto por GROSSMAN ${ }^{56}$. Verificaram que cimentos que apresentavam escoamentos altos na metodologia proposta pela ISO $^{68}$ e ADA ${ }^{9}$, demonstraram resultados extremamente insatisfatórios na desenvolvida por GROSSMAN $^{56}$. Porém, ficou a dúvida se no trabalho de ONO; MATSUMOTO ${ }^{104}$, o tempo para se medir foi insuficiente. Entretanto BIRMAN et al. ${ }^{21}$ avaliando o mesmo cimento (Sealapex) e a mesma metodologia (GROSSMAN ${ }^{56}$ ) empregada por ONO; MATSUMOTO ${ }^{104}$, tiveram valores bem baixos e similares aos dos dois em tempos prolongados, diante dessas observações se constata que a metodologia proposta por GROSSMAN ${ }^{56}$ favorece resultados discordantes da metodologia da $\mathrm{ISO}^{68}$ e $\mathrm{ADA}^{9}$. 
Com relação ao tempo de presa, BOVIS;HARRINGTON; WILSON ${ }^{24}$ empregaram, para averiguação dessa propriedade em materiais restauradores, um aparelho denominado reômetro e DEGEE; WU; WESSELINK ${ }^{31}$ utilizaram o mesmo método para a determinação do tempo de presa do Ketac-Endo e AH26. Esse aparelho, além de determinar a presa, também avalia a alteração volumétrica, sendo, portanto, um método vantajoso, pois não há necessidade do pesquisador ficar observando constantemente. Entretanto, requer o uso de equipamento especial. Na realização desse trabalho, os cimentos testados foram colocados em anéis de $10 \mathrm{~mm}$ de diâmetro e $2 \mathrm{~mm}$ de altura, sendo a presa constatada com o auxílio de agulha de Gilmore. Essa metodologia é recomendada tanto pela $\mathrm{ISO}^{68} \mathrm{como}$ pela $\mathrm{ADA}^{9}$, porém o peso empregado na agulha foi superior ao proposto pelas normas, que é de 100 gramas e diâmetro de $2 \mathrm{~mm}$, enquanto que a utilizada por nós possuía peso de 456,3 gramas e 1,06 mm de diâmetro, sendo essa mesma agulha utilizada também por MORAES ${ }^{99}$, que determinou 0 tempo de presa de cimentos obturadores endodônticos com resina epóxica na composição. Já ZYTKIEVITZ; LIMA; SOBRINHO ${ }^{156}$ empregaram três agulhas com pesos diferentes, sendo eles de 10 gramas, 50 gramas e 113,5 gramas para determinar tempo de presa de cimentos endodônticos. Agulha com peso de 113,5 gramas também foi empregada por TORABINEJAD et al. ${ }^{140}$ para avaliação de materiais obturadores retrógrados. Já McCOMB; $\mathrm{SMITH}^{89}$ empregaram peso de 300 gramas para determinação do tempo de presa de cimentos endodônticos. $O$ emprego de agulhas com pesos maiores, provavelmente, façam maiores marcações e por tempos mais prolongados conforme constatado por ZYTKIEVITZ; LIMA; SOBRINHO ${ }^{156}$. Já que quando da utilização do peso de 113,5 gramas o tempo de presa foi mais prolongado do que quando se utilizou agulhas com 10 gramas e 50 gramas. Contudo, quando se utiliza agulhas com pesos maiores os resultados com relação àpresa final do material ficam mais precisos. Diante disso, fica a dúvida do motivo pelo qual as normas da $\operatorname{ISO}^{68}$ e da $\operatorname{ADA}^{9}$ propõem o peso de 100 gramas, e não utiliza pesos maiores.

$\mathrm{Na}$ realização do teste de selamento apical se empregou dentes humanos unirradiculados, que têm sido os mais utilizados para a efetuação 
desses testes. (BRAMANTE; DUARTE; BRAMANTE ${ }^{25}$, HOLLAND et al. ${ }^{62,63}$, MORAES ${ }^{98,99}$ TANOMARU FILHO et al. ${ }^{138}$ ). Já WU; DEGEE; WESSELINK ${ }^{149}$ avaliando a influência da espessura do cimento no selamento apical utilizaram dentes bovinos, sendo que esse mesmo tipo de dentes também, foi utilizado por DEGEE; WU; WESSELINK ${ }^{31}$, na forma de cilindros com altura e diâmetros padronizados. GROSMAN ${ }^{56}$, em 1976 utilizou tubos de vidro para verificar o selamento de cimentos obturadores. Similar metodologia também foi empregada por ONO; MATSUMOTO ${ }^{104}$. Porém, o uso de tubos de vidro tem o inconveniente de fugir da realidade, pois o vidro apresenta uma lisura, além de não possuir túbulos dentinários. KERSTEN et al. ${ }^{77}$ em 1988, questionando as variações anatômicas que ocorrem em dentes humanos e que podem influenciar no selamento apical, acarretando variações nos resultados, descreveram um método para desenvolver dentina artificial e confeccionaram dentes com esse material, realizando testes de infiltrações com os mesmos, obtendo resultados mais uniformes. Entretanto, essa metodologia é difícil de ser realizada e também diverge da realidade, principalmente por não apresentar túbulos dentinários. Blocos de resina também já foram empregados para determinação do selamento apical (PANTHOMVANICH; EDMUNDS ${ }^{107}$ ) porém, apresentam as mesmas desvantagens que o tubo de vidro e dentina artificial. Diante do exposto, apesar do dente humano apresentar alguns inconvenientes, se aproxima mais da realidade sendo conforme já enfatizado, o mais empregado para análise dessa propriedade.

$\mathrm{Na}$ realização do trabalho manteve-se a coroas dos dentes e os mesmos foram abertos de maneira convencional conforme outros autores (BRAMANTE; DUARTE; BRAMANTE ${ }^{25}$, MORAES ${ }^{99}$, TANOMARU FILHO et al. ${ }^{138}$ ). Concluída a abertura coronária efetuou-se a padronização do forame até a lima $\mathrm{K}$ no 30 conforme já utilizada por BRAMANTE; DUARTE; BRAMANTE ${ }^{25}$ e TANOMARU FILHO et al. ${ }^{138}$. Já MORAES ${ }^{99}$ ampliou o forame até a lima $\mathrm{K} 40 \mathrm{e}$ $\operatorname{ALMEIDA}^{8}$ até a $\mathrm{K} \mathrm{n}^{\circ}$ 50. A padronização do forame visou manter a mesma abertura apical para todo os espécimes, proporcionando assim uma mesma área de contato entre o material e o corante, evitando uma fonte de variação que poderia favorecer oscilações nos resultados. A técnica de instrumentação utilizada 
foi a escalonada regressiva mantendo como instrumento de memória a lima $\mathrm{K}$ no 50 conforme já utilizada por outros autores ${ }^{25,}{ }^{138}$. Durante a etapa da instrumentação a solução irrigadora empregada foi o hipoclorito de sódio e ao final foi empregado o EDTA para remoção da Smear Layer, visto que esta promove influência significante no selamento apical de alguns cimentos ${ }^{28,35,98}$. Além disso, a sua remoção, em caso de necropulpectomia é imprescindível para favorecer uma melhor antissepsia.

Após a instrumentação procedeu-se àmpermeabilização da superfície externa dos dentes para, então, se realizar a obturação. Já ALMEIDA ${ }^{8}$ efetuou a obturação para então impermeabilizar, deixando os dentes sem contato com umidade durante 48 horas para a secagem do impermeabilizante. Com isso o cimento fica em ambiente seco durante a sua presa, fugindo da realidade clínica além do que, esse fato pode interferir nas características do material.

No que diz respeito àtécnica de obturação empregada, ut ilizamos a do cone único, onde o cimento foi levado antes com Lentullo para o interior do canal para então se assentar o cone principal, seguindo metodologia empregada em outros trabalhos ${ }^{25,99,138}$. Apesar de na clínica, a técnica mais empregada ser a condensação lateral e também ser a mais utilizada em trabalhos de infiltração $8,61,63,64,65,69$, alguns estudos ${ }^{12,61}$ não têm demonstrado diferenças entre elas, além disso a intenção do presente trabalho foi testar o cimento obturador e quando se realiza a condensação lateral, algumas fontes de variação podem influenciar; como a melhor familiarização do operador com determinado cimento, realizando obturações mais confiáveis com o mesmo. Outro fator que pode influenciar diz respeito ao número de cones acessórios a ser introduzidos no canal que pode variar de dente para dente, influenciando diretamente na capacidade seladora. Diante desses fatos é que optamos pela técnica do cone único, esperando que diante da mesma o cimento possa mostrar melhor sua real característica seladora.

Quanto àforma para se determinar o selamento inúmeras têm sido empregadas, como a infiltração bacteriana ${ }^{51,54,92,128,139}$ que pode ser avaliada histologicamente ${ }^{51}$ ou por meio de aparato ${ }^{139}$ em que o microrganismo $0^{51,54,139}$ ou 
saliva humana ${ }^{92,128}$ são colocados na porção coronária e a região apical fica imersa em caldo e quando esse se turvar significa que o microorganismo penetrou em toda extensão obturada. Porém, na avaliação pela turvação do meio, se determina apenas quantos dias se leva para ocorrer a penetração bacteriana em toda extensão do canal, além do que não há necessidade de que o microorganismo infiltre em toda extensão para agredir, visto que, eles podem liberar produtos com tamanhos menores que vão atingir pontos distantes e promover agressão. Atento àesses fatores KERSTEN; MOORER ${ }^{76}$, em 1989, verificaram 0 selamento de materiais endodônticos empregando produtos bacterianos, entre eles a endotoxina e o ácido butírico.

WU et al. ${ }^{151}$ desenvolveram um método de transporte propagativo de água da porção coronária para a apical, empregando a pressão de 1,2 atm de maneira que a infiltração é medida em um capilar conectado no ápice. Comparando esse método verificaram que obturações que sofreram o transporte de fluido não permitiram a passagem de bactérias. Essa metodologia tem sido empregada em outros trabalhos ${ }^{31,149}$ porém, tem a desvantagem de utilizar aparatos especiais e também de necessitar de infiltração em toda extensão da raiz para se quantificar.

Outro método empregado é o eletroquímico ${ }^{69}$, em que os ápices dos dentes são imersos em solução eletrolítica e um metal é inserido na câmara pulpar, de modo que, no momento em que a solução infiltra através da obturação o metal se corroe estabelecendo a quantidade média de infiltração. Apresenta também como desvantagem de necessitar de aparato especial para sua execução e também da infiltração total da solução.

O emprego de marcadores tem sido o método mais utilizado para determinar a infiltração, sendo que os mesmos podem ser radioisótopos ${ }^{62,72,95,116}$ que apresentam fatores que influenciam na medição, como a qualidade da auto radiografia, para se determinar a infiltração correta do radioisótopo sendo. A qualidade da auto radiografia depende de uma série de fatores, como a média de radiação, tamanho dos grânulos da emulsão, método de processamento e concentração do radioisótopo sendo, inclusive necessário a realização de estudos 
pilotos, principalmente para determinar a concentração máxima e mínima do isótopo e determinação do tempo de processamento, para se obter imagens mais confiáveis $^{72}$.

Os marcadores mais utilizados têm sido os corantes, entre eles a tinta Nankin ${ }^{2,112,118}$, Rhodamine $\mathrm{B}^{82}$, Verde da Prússia ${ }^{136}$, Eosina ${ }^{111}$ porém, o mais empregado é o azul de metileno ${ }^{5,14,25,32,52,61,66,69,80,87,88,99,138}$ que foi o utilizado no presente trabalho. Apesar de ser um corante com partículas extremamente pequenas, menor que os microrganismos e ser questionado seu uso, ele apresenta moléculas compatíveis com o daquelas do ácido butírico que é um produto bacteriano tóxico (KERSTEN ${ }^{76}$ 1989). O azul de metileno tem que apresentar, idealmente, um pH neutro, visto que alterações no mesmo podem influenciar no grau de infiltração, dependendo do material. (STARKEY; ANDERSON; PASHLEY ${ }^{133}$ ). Outro fator que varia é a concentração do corante, sendo que a mais utilizada para marcar a infiltração em obturações endodônticas tem sido a solução aquosa de azul de metileno a $2 \%{ }^{25,80,138}$. Porém WU; KONTAKIOTIS; WESSELINK ${ }^{150}$ têm demonstrado que o azul de metileno pode ser descolorido por algumas substâncias, entre elas o hidróxido de cálcio e esse fato tem posto em dúvida alguns trabalhos ${ }^{61,64,113}$ que demonstram que resíduos de pasta de hidróxido de cálcio favorecem o selamento em obturações endodônticas. Contudo, no trabalho de WU; KONTAKIOTIS; WESSELINK ${ }^{150}$ o volume de azul de metileno empregado foi pequeno, ficando a dúvida se em volumes maiores esse fato também ocorre. No Index Merk ${ }^{97}$ é relatado que o azul de metileno é incompatível com o pH alcalino e sofre alterações na presença de zinco, porém TANOMARU FILHO et al. ${ }^{138}$ comparando o Sealapex e o cimento de óxido de zinco eugenol com o Sealer 26, obtiveram resultados significantemente melhores com o último, embora o Sealapex apresenta pH mais alcalino que o Sealer 26 , conforme já demostrado ${ }^{125}$. Tal fato também foi constatado por LIMKANGWALMONGKOL et al. ${ }^{87}$ que confrontando o Sealapex com o Apexit e AH26 observou piores resultados com primeiro e o mesmo é o cimento que apresenta $\circ \mathrm{pH}$ mais alcalino. Portanto, acreditamos que problemas relatados 
quanto àdescoloração e àncompatibilidade do azul de metileno com substâncias alcalinas devem ser melhores estudados.

Quanto aos métodos de quantificação da infiltração, a mesma pode ser mensurada após seccionamento dental ${ }^{25,75,138}$, clareação dos dentes ${ }^{136}$ ou volumetricamente ${ }^{32,70,90,113,153}$. Porém, para realização da clareação, só é possível se o corante for a tinta Nankin ou o Verde da Prússia, pois o azul de metileno, quando da descalcificação é removido pelo ácido e, baseado nesta premissa, que ZAKARASSEN; DOUGLAS; STADEM ${ }^{153}$ desenvolveram a medição volumétrica, em que as secções dos dentes, após a infiltração são colocadas no ácido cítrico e a infiltração ocorrida é medida volumetricamente através de espectrofotômetro. MADISON; ZAKARIASEN ${ }^{90}$ comparando a medição volumétrica e linear, verificaram baixa correlação entre a infiltração linear e volumétrica, ou seja, os resultados da infiltração volumétrica foram distintos da linear. Já PORKAEW et al. ${ }^{113}$ observaram o inverso, os resultados da infiltração linear coincidiram com a medição volumétrica. Porém, no trabalho de PORKAEW et al. ${ }^{113}$ foi testada a influência de restos de curativos de hidróxido de cálcio no selamento das obturações endodônticas. Como a pasta de hidróxido de cálcio pode levar à obliteração dos túbulos dentinários evitando assim que o corante penetre na massa dentinária, isso pode ter favorecido a concordância entre a medição linear e volumétrica. No presente trabalho a infiltração foi determinada linearmente por meio de seccionamento longitudinal e medição com 0 auxílio de ocular micrometrada, seguindo metodologia de outros autores ${ }^{25,80,98,99,138}$. Essa forma de análise tem a vantagem de ser de realização muito fácil e a desvantagem de limitar a área avaliada porém, tem sido o método mais empregado e por isso foi o eleito para realização desse trabalho.

Entretanto, há de ressaltar que na análise da capacidade seladora pode-se constatar que as metodologias oscilam muito, acarretando numa dificuldade da interpretação e confronto dos resultados entre os autores, sendo tal fato atribuído a não normatização dessa avaliação.

Além desse fato, tem que se enfatizar que um material pode produzir um bom selamento, porém pode apresentar um comportamento clínico ruim, pois 
PITTFORD $^{111}$ demonstrou em um trabalho, correlacionando a capacidade seladora com o comportamento clínico que materiais que selaram bem; apresentaram os piores resultados clínicos.

Com relação àdeterminação do $\mathrm{pH}$, tem -se verificado a liberação do íon hidroxila, tanto em condições in vivo ${ }^{39,142}$ como in vitro $26,33,42,53,101,125,126,135$.

No método in vivo, TRONSTAD et al. ${ }^{142}$, em 1981, determinaram o $\mathrm{pH}$ da dentina de dentes de macaco, após o tratamento de seus canais com hidróxido de cálcio. Utilizaram para análise, marcadores, onde um corante era colocado superficialmente àraiz do dente e, então, se difundia em direção ao canal. A alteração da cor do corante e o indicador ditava o pH nos diferentes pontos da dentina radicular. Concluíram ser o método eficiente, porém, o cuidado de se colocar o corante primeiro na superfície é de suma importância para evitar ou reduzir o fenômeno da difusão.

ESTRELA; PESCE ${ }^{38}$ utilizaram tubos de polietileno preenchidos com hidróxido de cálcio e que foram implantados em tecido subcutâneo de cão. Avaliaram a liberação de íon cálcio e por analogia, de hidroxila. Os tubos eram implantados e deixados por períodos estipulados, depois removidos e a pasta, então, titulada e medida com auxílio de condutímetro. Alguns cuidados devem ser tomados como, corrigir o fator de condutibilidade pela diluição, pois a mesma reduz a condutibilidade durante a titulação. Outro aspecto é o transporte dos tubos após a remoção do tecido, que deve ser feito em vidro inerte, contendo atmosfera de nitrogênio, procurando evitar a presença de oxigênio que, pode reagir com o cálcio e influir na análise da liberação.

Nos métodos in vitro, com auxílio de pHmetro e microeletrodos, NERWICH et al. ${ }^{101}$ determinaram o $\mathrm{pH}$ da dentina proporcionado pelo hidróxido de cálcio. Esta metodologia também foi empregada por ESBERARD; CARNES; DELRIO ${ }^{37,38}$. NERWICH et al. ${ }^{101}$ analisaram o $\mathrm{pH}$ da raiz, interna e externamente, averiguando assim, a capacidade tampão da dentina. Já ESBERARD; CARNES; DEL $\mathrm{RIO}^{37,38}$, determinaram $\circ \mathrm{pH}$ apenas nas superfícies radiculares externas radiculares, após o preparo de cavidades com brocas, bastante superficiais, com o intuito de, apenas, remover o cemento, que é uma barreira àdifusão do íon 
hidroxila (NERWICH et al. ${ }^{101}$ ). Há de ressaltar que no período inicial o pH da raiz, internamente, pode apresentar-se alcalino devido ao resíduo de hipoclorito de sódio utilizado no preparo biomecânico; $\mathrm{pH}$ este que não condiz com a realidade (ESBERARD; CARNES; DELRIO ${ }^{37,38}$ ).

Ao invés do emprego do pHmetro, o $\mathrm{pH}$ da dentina, pode também ser determinado com a utilização de corantes como vermelho cresol a 1\% (STAEHLE et al. ${ }^{131}$ ), porém, este método não fornece valores absolutos (quantitativos). O que se consegue é uma determinação visual, se ocorreu ou não a alcalinização. Já ESTRELA et al. ${ }^{42}$, utilizando uma solução indicadora universal, determinaram também os valores da alcalinização da dentina. Entretanto, enfatizaram que alguns cuidados, neste método, devem ser tomados para evitar possíveis variáveis. Citam como tais, a presença de oxigênio e luz. Assim, após a secção, o dente deve ser mantido em plataformas inertes e em uma atmosfera de nitrogênio completamente selada, na ausência de luz e àtemperatura de $36,5^{\circ} \mathrm{C}$.

Outros autores ${ }^{10,108}$, após espatularem o material, colocam-no direto na solução dissolvendo-o e medindo o seu pH.

A metodologia que empregamos consiste em imergir os materiais, em teste na solução, porém, acondicionados em recipientes específicos e depois com auxílio de pHmetro (ANTHONY; GORDON; ALEXANDER ${ }^{10}$ ) ou potenciômetro (TAMBURIC; VULETA; OGNJANOVIC ${ }^{137}$ ) determinar o pH da solução, Em nosso trabalho foi utilizado o pHmetro, esta metodologia tem sido amplamente empregada para determinação do pH de pastas de hidróxido de cálcio, elaboradas com os mais diferentes veículos (ANTHONY; GORDON; DEL RIO ${ }^{10}$, STAMOS; HAASH; GERSTEIN ${ }^{132}$; SIMON; BATH; FRANCIS ${ }^{126}$, PENICHE; SAMPAIO; COLLESI $^{108}$ ) ou de materiais forradores e obturadores (GORDON; ALEXANDER ${ }^{53}$, TAGGER; TAGGER; KFIR ${ }^{135}$, LEONARDO et al. ${ }^{84}$; SIQUEIRA JÚNIOR; FRAGA; GARCIA $^{127}$, DUARTE ${ }^{33}$, SILVA et al. ${ }^{125}$ ). Alguns autores têm colocado o material dentro do canal radicular (GORDON; ALEXANDER ${ }^{53}$, SIMON; BATH; FRANCIS $^{126}$ ). Há que ser ressaltado que, quando do emprego de dentes, um cuidado especial deve ser tomado com relação àpadroniz ação dos forames apicais em relação ao diâmetro dos tubos. Resultados diferentes, entre 
pesquisas, podem ser obtidos se isto não for observado, pois, áreas de contato menores, com certeza, apresentarão valores de $\mathrm{pH}$ mais baixos, desde que a quantidade de solução para imersão dos espécimes seja a mesma.

DUARTE $^{33}$ utilizou tubos com diâmetro de $2 \mathrm{~mm}$, padronizando-o para todos materiais evitando, assim, a influência de diferentes áreas de contato que favoreceria discrepâncias nos resultados. Nesse trabalho, também se utilizou tubos com aberturas padronizadas porém, com diâmetros menores, de $1 \mathrm{~mm}$. A mesma metodologia também foi utilizada por BELTES et al. ${ }^{16}$ para se determinar o $\mathrm{pH}$ de pastas de hidróxido de cálcio.

Outro fator, foi com relação àsolução, que no tra balho de DUARTE ${ }^{33}$ ela era substituída após cada período de leitura, enquanto que no presente trabalho os tubos foram imersos em $20 \mathrm{~mL}$ de solução e a cada período $4 \mathrm{~mL}$ da solução eram retirados para leitura do $\mathrm{pH}$. Com isso sempre se obteve uma ascendência nos valores de $\mathrm{pH}$, enquanto que substituindo a solução, os resultados podem oscilar mais porém favorece, uma noção do ponto em que ocorreu a maior liberação.

A incubação a $37^{\circ} \mathrm{C}$ do conjunto frasco-solução e espécime foi feita em condições de aerobiose visto que, FUSS et al. ${ }^{48}$, em 1996, demonstraram que tanto em aerobiose como em anaerobiose, o pH não difere.

Em última instância, vale ressaltar que a intenção com essa metodologia foi avaliar a capacidade de cada material propiciar a liberação de íon hidroxila. Não se pode olvidar que, clinicamente existem fatores que poderão influir no pH do material, levando-o com certeza a uma redução e, é claro, esses valores obtidos neste trabalho, com certeza não serão exatamente iguais घ̀ueles encontrados em clínica.

Na determinação da liberação de íons cálcio, várias metodologias têm sido propostas. ESTRELA; PESCE ${ }^{39}$ estudaram in vivo a liberação de íons cálcio de pastas de hidróxido de cálcio com diferentes veículos. Utilizando tubos com os materiais inseridos em tecido subcutâneo de cão, após diferentes períodos removiam os tubos e, por meio de analogia determinaram quanto de cálcio havia sido liberado para o tecido. Essa metodologia é a que demonstra melhor a 
realidade, porém a sua execução é de extrema dificuldade, além da necessidade de saber-se precisamente o quanto de cálcio tem no material testado.

GUIGUAND et al. ${ }^{58}$ compararam a liberação de cálcio in vitro de uma pasta de óxido de cálcio com uma de hidróxido de cálcio, utilizando dentes de porco, extraídos. Quantificaram por meio de microanálise, em microscopia de varredura, a liberação de cálcio para a massa dentinária. Essa metodologia apresenta o inconveniente de necessitar-se de equipamento especial, nada mais do que o microscópio eletrônico de varredura.

O método mais empregado para esse tipo de análise consiste no acondiciomamento do material em tubos (TAGGER; TAGGER; KFIR ${ }^{135}$, SILVA et al. ${ }^{125}$ ) ou dentes extraídos (SIMON; BHAT; FRANCIS ${ }^{126}$, ÇALT et al. ${ }^{26}$ ) e determinação da liberação de cálcio pelo emprego de potenciômetro com eletrodo seletivo para cálcio (TAMBURIC; VULETTA; OGNJANOVIVC ${ }^{137}$, ÇALT et al. ${ }^{26}$ ), por meio de titulação e analisador específico de cálcio, sendo um método titulométrico (TAGGER; TAGGER; KFIR ${ }^{135}$ ) ou por intermédio de espectrofotômetro de absorção atômica (LEONARDO et al. ${ }^{84}$, SILVA et al. ${ }^{125}$ ). Em nosso trabalho os cimentos foram acondicionados em tubos, visto que quando do uso de dentes, fica a dúvida se o cálcio liberado e encontrado na solução é decorrente apenas do cálcio do material em estudo, e não faz parte do cálcio do dente. Diante dessa dúvida é que se deu preferência ao uso de tubos.

Os tubos preenchidos com os materiais foram imersos individualmente em frascos contendo $20 \mathrm{~mL}$ da solução e nos períodos estipulados, $4 \mathrm{~mL}$ da solução foram retirados para determinação do cálcio. Para a leitura do cálcio liberado, empregou-se o espectrofotômetro de absorção atômica, que determina o cálcio ionizado e também o que está na solução e ainda não se ionizou. Com o emprego do potenciômetro, ocorre a determinação eletrolítica, ou seja, se quantifica apenas o cálcio ionizado, portanto se houver na solução cálcio que ainda não ionizado e que com o tempo se ionizará, o potenciômetro não acusará. Portanto, com o uso do potenciômetro, a leitura efetuada pode ser muitas vezes inferior a realidade, diante desses argumentos é que se optou pelo 
espectrofotômetro de absorção atômica. Quanto ao método titulométrico, esse se apresenta como o menos confiável.

\section{2 - Dos resultados}

$\mathrm{O}$ cimento AH Plus que, neste trabalho foi avaliado e modificado com acréscimo de hidróxido de cálcio consiste de um derivado do $\mathrm{AH} 26$, tratando-se de um material com resina epóxica na composição, cujas modificações favoreceram a sua apresentação na forma de duas pastas. Alguns componentes do $\mathrm{AH} 26$ foram substituídos, entre eles o endurecedor; sendo outros acrescentados.

Apesar de favorecer a espatulação durante a sua manipulação, se constatou uma fluidez elevada que foi comprovada pelo teste de escoamento que apresentou o diâmetro de $40,25 \mathrm{~mm}$, em média. Já o fabricante relata um valor de $36 \mathrm{~mm}$, portanto abaixo do observado nesse trabalho. MORAES ${ }^{99}$ avaliando o $\mathrm{AH}$ 26 em metodologia similar à empregada nesse trabalho, constatou um escoamento de $45 \mathrm{~mm}$, então, maior do que o do AH Plus. Já ZYTKIEVITZ; LIMA; SOBRINHO ${ }^{156}$, testando o $\mathrm{AH} 26 \mathrm{com}$ um peso de 100 gramas, obtiveram escoamento de $33 \mathrm{~mm}$ e com 500 gramas o valor foi de $45 \mathrm{~mm}$, divergindo um pouco de MORAES ${ }^{99}$ que utilizou peso de 120 gramas. Porém, os valores encontrados neste trabalho demonstram que o $\mathrm{AH}$ Plus apresentou valores elevados (40,25mm), estando bem acima do mínimo recomendado pela $150^{68} \mathrm{e}$ $\mathrm{ADA}^{9}$, de $20 \mathrm{~mm}$ e $25 \mathrm{~mm}$ respectivamente. Essa fluidez é elevada e, clinicamente averiguamos ser um material com manipulação inadequada. MORAES ${ }^{\star}$ relatou casos clínicos de extravazamento em obturações de canais realizadas com o $\mathrm{AH}$ Plus. Procurando diminuir a fluidez do AH Plus, foi que se propôs acrescentar $5 \mathrm{e}$ $10 \%$ de hidróxido de cálcio no material. Com isso pode-se verificar uma redução no escoamento, obtendo-se valores de $37 \mathrm{~mm}$ quando se acresceu $5 \%$ e 27,25 $\mathrm{mm}$ com o acréscimo de 10\%, mantendo-se esses dois valores acima, ainda, do mínimo recomendado pela $I S O^{68}$ e $\operatorname{ADA}^{9}$. Com relação ao óxido de zinco e

\footnotetext{
* Comunicação pessoal
} 
eugenol, o valor do escoamento foi de $33 \mathrm{~mm}$, similar ao observado por MORAES $^{99}$, que foi de $32,8 \mathrm{~mm}$. Isso é atribuído ao fato de se ter utilizado proporcionamento e metodologia similares, no presente trabalho. Já ZYTIKIEVITZ; LIMA; SOBRINHO ${ }^{156}$ obtiveram valores diferentes e menores daqueles obtidos por MORAES ${ }^{99}$ e o presente trabalho, sendo tal fato atribuído ao proporcionamento, pois ZYTIKIEVITZ; LIMA; SOBRINHO ${ }^{156}$ empregaram uma mistura mais consistente.

Outra propriedade analisada foi o tempo de presa. Constatou-se que para o AH Plus o valor foi de $+/-14 \mathrm{~h} \mathrm{em}$ ambiente seco e de $15 \mathrm{~h}$ em ambiente úmido. O fabricante estipula na bula, um tempo de $8 \mathrm{~h}$, no mínimo, a $37^{\circ} \mathrm{O}$. $\mathrm{O}$ tempo de presa encontrado nesse trabalho, foi bem maior do mínimo do fabricante, que é de $8 \mathrm{~h}$. Tal fato pode ser atribuído àdiferença de peso das agulhas empregadas nos diversos testes que variam de 100 gramas até a que foi empregada no presente trabalho (453,6 gramas). Já MORAES ${ }^{99}$, testando o $\mathrm{AH}$ 26 , encontrou a presa em 40 horas em temperatura ambiente e 17 horas em ambiente úmido. Um fato observado em nosso trabalho foi que a umidade não acelerou o tempo de presa do $\mathrm{AH}$ Plus como acontece em outros cimentos ${ }^{99}$. Esse fato, provavelmente seja devido a ele possuir óleo de silicona na composição e esse, talvez, evitasse a influência da umidade. Com relação ao acréscimo de hidróxido de cálcio constatou-se que não houve interferências significantes conforme dados da TABELA 1 levando, inclusive, a uma ligeira aceleração do tempo de presa. MORAES ${ }^{99}$, acrescendo hidróxido de cálcio ao AH 26 encontrou um pequeno retardamento no tempo de presa. $O$ tempo de presa constatado para o óxido de zinco e eugenol foi similar a aquele obtido por MORAES ${ }^{99}$, que utilizou metodologia e proporção similares àempregada neste trabalho.

Com relação àradiopacidade, se co nstatou um valor alto para $0 \mathrm{AH}$ Plus. BEYER-OLSEN; ORSTAVIK ${ }^{19}$ e BOSCOLO; BENATTI; GONÇALVES ${ }^{23}$, obtiveram valores maiores para o $\mathrm{AH}$ 26, sendo que BEYER-OLSEN; ORSTAVIK ${ }^{19}$ obtiveram um valor de $6,66 \mathrm{~mm}$ de alumínio, empregando metodologia semelhante. Para o AH Plus se constatou, uma radiopacidade equivalente a 6,94 mm de alumínio. O radiopacificador no $\mathrm{AH}$ Plus é diferente 
daquele do $\mathrm{AH} 26$, sendo que no primeiro o radiopacificador é o óxido de zircônio que possui coloração branca e é encontrado na natureza no mineral badileita e é utilizado em dermatologia. Já, no segundo, o radiopacificador é o óxido de bismuto que apresenta coloração amarela e é encontrado na natureza no metal bismita sendo utilizado como adstringente.

Quanto ao acréscimo de hidróxido de cálcio tanto, na proporção de 5\% e $10 \%$, observa-se que não houve não influência significante na radiopacidade quando observadas as Tabelas 4 e 5 . Em comparação ao óxido de zinco e eugenol e àguta -percha, a radiopacidade do AH Plus Puro e com 5\% a $10 \%$ de hidróxido de cálcio, foi significantemente superior; porém todos os materiais testados quanto à essa propriedade, apresentaram resultados superiores ao mínimo estipulado pela $\mathrm{ISO}^{68}$ e $\mathrm{ADA}^{9}$ que é de 3 e $4 \mathrm{~mm}$ respectivamente.

Com relação ao selamento apical pode-se observar pelos resultados que o AH Plus puro apresentou infiltração similar ao óxido de zinco e eugenol, não apresentando, portanto, resultados satisfatórios. O valor médio da infiltração apical foi de 2,893 mm. ANTONOPOULOS; ATTIN; HELLWIG ${ }^{12}$ realizando obturações pela técnica do cone único e penetração passiva do corante encontraram infiltração de $1,58 \mathrm{~mm}$, porém o corante empregado foi a tinta da Índia, enquanto que neste trabalho foi empregado o azul de metileno. Este apresenta moléculas de tamanho bem menores, o que favorece uma infiltração maior, conforme comprovação de AHLBERG; ASSAVANOP; TAY ${ }^{2}$. ALMEIDA ${ }^{8}$ encontrou para o AH Plus infiltração de $1,01 \mathrm{~mm}$, porém em seu trabalho ele empregou o cone ultrapassando além ápice, diminuindo a película de cimento e também realizou a condensação lateral ativa. A redução da película de cimento favorece o selamento do mesmo, conforme observações de DEGGE; WU; WESSELINK ${ }^{31}$. Outro fator foi que a presa do cimento ocorreu em ambiente seco, e paira a dúvida se a umidade não interferiria no selamento proporcionado pelo AH Plus. Apesar de ser derivado do $\mathrm{AH} 26$, um cimento que apresenta boa capacidade seladora, o comportamento do $\mathrm{AH}$ Plus com relação a essa propriedade não tem sido semelhante e tal fato foi confirmado por ZMENER et al. ${ }^{155}$, que comparando o $\mathrm{AH}$ Plus com o $\mathrm{AH} 26$, constataram piores resultados por parte do primeiro, apresentando, inclusive, 
diferença significante. Tencionando explicar tal ocorrência, ZMENER et al. ${ }^{155}$ levantaram a hipótese de que a presa mais rápida do AH Plus levaria um estresse de contração maior, levando a uma desunião s̀ paredes dentinárias favorecendo a infiltração. Outra hipótese levantada para explicar os piores resultados por parte do AH Plus é a presença do óleo de silicona e outros ingredientes e como todos espécimes foram mantidos em $100 \%$ de umidade, pode ser especulado que o $\mathrm{AH}$ Plus, pela presença do óleo, se aderiria pobremente àdentina úmida, formando espaços na interface cimento-dentina favorecendo a infiltração. PORKAEW et al. ${ }^{113}$ testando a influência de resíduos de hidróxido de cálcio no selamento de obturações endodônticas constataram que a Vitapex, uma pasta que contém óleo de silicone proporcionou a maior infiltração, sustentando a hipótese levantada por ZMENER et al. ${ }^{155}$. Os valores obtidos por ZMENER et al. ${ }^{155}$ foram altos após 10 dias sendo, 3,3 mm para o AH Plus empregando condensação lateral ativa. No que diz respeito ao acréscimo de hidróxido de cálcio foi constatada uma melhora significante no selamento, tanto para proporção de $5 \%$ como para a de $10 \%$. Isso vem corroborar com os achados de outros autores ${ }^{25,63,65,138}$ que demonstraram que cimentos que possuem óxido de cálcio ou hidróxido de cálcio na composição apresentaram resultados melhores que os demais. MORAES ${ }^{99}$, desenvolveu cimentos epóxicos com hidróxido de cálcio na composição, e observou melhor capacidade seladora por parte desses quando comparados ao $\mathrm{AH} 26$, que é um cimento a base de resina epóxica, sem hidróxido de cálcio.

Porém, fica a dúvida se a melhor capacidade seladora não seria devido a descoloração do azul de metileno pelo hidróxido de cálcio, conforme já demonstrado ${ }^{150}$, ou devido à incompatibilidade do corante com substâncias alcalinas $^{97}$. Entretanto, analisando os resultados desse trabalho pode-se verificar que o $\mathrm{AH}$ Plus com $5 \%$ de hidróxido de cálcio apresentou infiltração ligeiramente menor que o AH Plus com $10 \%$ de hidróxido de cálcio, contrariando as dúvidas anteriores, visto que, o cimento com $10 \%$ apresentou $\mathrm{pH}$ um pouco mais alcalino e, portanto, deveria infiltrar menos e, pela lógica levaria a uma maior descoloração pois possui uma maior quantidade de hidróxido de cálcio. Este fato não foi observado. Entretanto, acreditamos que o melhor selamento conseguido, foi 
devido uma melhora na característica de manipulação, e tal fato pode ser subsidiado por KUGA; MORAES; BERBERT ${ }^{80}$ que acresceram iodofórmio ao Sealapex, visando melhorar a radiopacidade do material e manipulação e constataram melhora no selamento.

Constatou-se em todos os grupos, uma grande oscilação nos resultados da infiltração. Tal ocorrência pode ser atribuída àvariações anatômicas entre os dentes empregados, conforme já chamado àatenção por KERSTEN et al. ${ }^{77}$, Tentando amenizar este fato é que empregou-se para o confronto estatístico um teste não paramétrico pois, quando ocorre essas variações é o teste mais indicado (KERSTEN et al. ${ }^{77}$, SCHURRS et al. ${ }^{121}$ ).

Outras propriedades físico-químicas analisadas foram $\mathrm{opH}$ e a liberação de cálcio. Pode-se constatar que os acréscimos de 5 e 10\% de hidróxido de cálcio favoreceram um pH mais alcalino e maior liberação de cálcio em relação ao cimento $\mathrm{AH}$ Plus puro concordando com outros autores ${ }^{84,125,135}$ que têm observado em cimentos com óxido de cálcio e hidróxido de cálcio na composição, que os mesmos favorecem o pH alcalino e maior liberação de cálcio. Essa alcalinidade maior e a liberação de cálcio favorecem um comportamento biológico e microbiológico melhor, visto que o $\mathrm{pH}$ mais alcalino leva a um favorecimento na deposição de tecido mineralizado além de propiciar uma ação antimicrobiana (ESTRELA et al. ${ }^{41,43}$ ). Quanto ao cálcio, ele favorece a mineralização, visto que o cálcio reage com o gás carbônico tecidual formando carbonato de cálcio, que é um cristal que serve de núcleo para a calcificação (SEUX et al. ${ }^{123}$ ). Porém, existe um nível de $\mathrm{pH}$ e liberação cálcio ótimo, pois o $\mathrm{pH}$ muito alto e uma grande quantidade de cálcio liberado, podem prejudicar a migração fibroblástica, conforme observado por LENGHENDEN et al. ${ }^{83} \mathrm{e}$, portanto, prejudicará o processo de reparo.

Observando os resultados deste trabalho pode-se deduzir que tanto, no acréscimo de $5 \%$ como no de $10 \%$, o pH e liberação de cálcio não foram tão elevados o que com certeza, não prejudicaria a migração fibroblástica.

Com relação ao AH Plus, apesar de possuir tungstênio de cálcio na composição, a liberação de cálcio, praticamente, não ocorreu, visto que os valores 
desse cimento foram similares aos do óxido de zinco e eugenol, e os mesmos foram considerados como, praticamente nulos.

\section{3 - Considerações finais}

Apesar do AH Plus ter apresentado resultados biológicos satisfatórios ${ }^{8}$, a proposta do acréscimo de hidróxido de cálcio teve a intenção inicial de melhorar a manipulação desse cimento. Pode-se constatar que 0 acréscimo dessa substância ao AH Plus não interferiu significantemente nas propriedades tendo, inclusive favorecido algumas, como pH e liberação de cálcio e infiltração apical. Além disso, o hidróxido de cálcio é uma substância que apresenta bom comportamento biológico e deve favorecer mais o aspecto biológico do AH Plus, visto que, tal premissa foi comprovada por BERBERT ${ }^{18}$ que acrescendo hidróxido de cálcio ao $\mathrm{AH} 26$ observou uma melhora biológica significativa por parte desse cimento. Então, acreditamos que o acréscimo de hidróxido de cálcio ao AH Plus, talvez leve, também, aos mesmos resultados.

Com relação \&̀ duas proporções utilizadas a de $5 \%$ foi melhor quanto a fluidez, visto que $10 \%$ tornou o cimento muito espesso conforme pode-se constatar nos valores de escoamento que ficaram bem próximos do mínimo recomendado pela $\operatorname{ADA}^{9}$. Já, com a proporção de $5 \%$ se obteve um escoamento melhor, por isso optamos para essa proporção. Biologicamente, paira a dúvida.

Porém, uma pergunta pode ser feita. Como o clínico estipularia essa proporção, visto que a maioria não possui balança de precisão no consultório?

Realizando alguns testes estipulamos que colocando porções iguais, correspondentes um fio de $1,5 \mathrm{~cm}$ de pastas base e catalisadora se deve colocar meia concha da medida que acompanha o IRM, de pó de hidróxido de cálcio na placa, dividir essa quantia na metade e essa metade deve ser dividida novamente ao meio, tendo-se, assim, um quarto da quantidade inicial. Esse um quarto deve, então, ser agregado aos $1,5 \mathrm{~cm}$ das pastas base e catalisadora. 


\section{7 - CONCLUSÕES}




\section{7 - CONCLUL ÕES}

Através da análise dos resultados e da discussão pertinente, pudemos concluir que o acréscimo de hidróxido de cálcio no cimento AH Plus nas proporções de $5 \%$ e $10 \%$ em peso:

a) Não interferiu, significantemente no tempo de presa do material;

b) Não acarretou em alterações significantes da radiopacidade do material;

C) Favoreceu uma melhora significante da capacidade seladora do material; $(p<0,05)$

d) Tornou o cimento menos fluido, melhorando o escoamento, principalmente na proporção de $5 \%$. Já com o acréscimo de 10\%, o cimento ficou muito espesso;

e) Propiciou um pH mais alcalino por parte do cimento e uma maior liberação de cálcio, sendo esse valores maiores na proporção de 10\% que se diferenciou estatisticamente dos demais na liberação de cálcio $(p<0,05)$, enquanto que no $\mathrm{pH}$ se diferenciou do OZE e AH Plus puro $(p<0,05)$. 
ANEXOS 
ANEXO 1 - Valores das densidades radiográficas para a escala de $\mathrm{mm}$ de alumínio do penetrômetro

\begin{tabular}{c|c} 
Mm de Al. & Densidade radiográfica \\
\hline $\mathbf{0}$ & 6,62 \\
\hline $\mathbf{1}$ & 59,16 \\
\hline $\mathbf{2}$ & 96,19 \\
\hline $\mathbf{3}$ & 124,03 \\
\hline $\mathbf{4}$ & 145,24 \\
\hline $\mathbf{5}$ & 162,07 \\
\hline $\mathbf{6}$ & 176,46 \\
\hline $\mathbf{7}$ & 244,41
\end{tabular}


ANEXO 2 - Valores do pH do cimento AH Plus com $10 \%$ de hidróxido de cálcio

\begin{tabular}{|c|c|c|c|c|c|}
\hline & $\mathbf{2 4 h}$ & $\mathbf{4 8 h}$ & $\mathbf{7 d}$ & $\mathbf{1 4 d}$ & $\mathbf{3 0 d}$ \\
\hline $\mathbf{1}$ & 7.10 & 7.34 & 7.28 & 8.00 & 8.00 \\
\hline $\mathbf{2}$ & 7.18 & 7.23 & 7.45 & 8.00 & 8.10 \\
\hline $\mathbf{3}$ & 7.26 & 7.33 & 7.45 & 7.95 & 8.00 \\
\hline $\mathbf{4}$ & 7.28 & 7.30 & 7.50 & 8.00 & 8.00 \\
\hline $\mathbf{5}$ & 7.09 & 7.27 & 7.44 & 8.01 & 8.00 \\
\hline $\mathbf{6}$ & 7.20 & 7.33 & 7.51 & 7.94 & 8.00 \\
\hline $\mathbf{7}$ & 7.47 & 7.61 & 7.70 & 8.01 & 8.04 \\
\hline $\mathbf{8}$ & 7.27 & 7.16 & 7.45 & 8.00 & 8.02 \\
\hline $\mathbf{9}$ & 7.25 & 7.39 & 7.54 & 7.90 & 8.00 \\
\hline $\mathbf{1 0}$ & 7.24 & 7.72 & 7.80 & 8.00 & 8.10 \\
\hline
\end{tabular}


ANEXO 3 - Valores do $\mathrm{pH}$ do cimento AH Plus com $5 \%$ de hidróxido de cálcio

\begin{tabular}{|c|c|c|c|c|c|}
\hline & $\mathbf{2 4 h}$ & $\mathbf{4 8 h}$ & $\mathbf{7 d}$ & $\mathbf{1 4 d}$ & $\mathbf{3 0 d}$ \\
\hline $\mathbf{1}$ & 7.05 & 7.30 & 7.33 & 7.90 & 8.00 \\
\hline $\mathbf{2}$ & 7.15 & 7.17 & 7.24 & 8.00 & 8.10 \\
\hline $\mathbf{3}$ & 6.95 & 7.25 & 7.26 & 7.95 & 7.97 \\
\hline $\mathbf{4}$ & 7.40 & 7.20 & 7.35 & 7.98 & 8.00 \\
\hline $\mathbf{5}$ & 7.18 & 7.45 & 7.45 & 8.00 & 8.00 \\
\hline $\mathbf{6}$ & 7.15 & 7.16 & 7.49 & 7.95 & 7.97 \\
\hline $\mathbf{7}$ & 7.16 & 7.25 & 7.50 & 7.90 & 7.97 \\
\hline $\mathbf{8}$ & 7.36 & 7.36 & 7.62 & 7.95 & 7.97 \\
\hline $\mathbf{9}$ & 7.24 & 7.35 & 7.48 & 7.95 & 7.98 \\
\hline $\mathbf{1 0}$ & 7.20 & 7.36 & 7.45 & 7.90 & 7.99 \\
\hline
\end{tabular}


ANEXO 4 - Valores do $\mathrm{pH}$ do cimento AH Plus puro

\begin{tabular}{|c|c|c|c|c|c|}
\hline & $\mathbf{2 4 h}$ & $\mathbf{4 8 h}$ & $\mathbf{7 d}$ & $\mathbf{1 4 d}$ & $\mathbf{3 0 d}$ \\
\hline $\mathbf{1}$ & 6.77 & 7.09 & 7.30 & 7.40 & 7.75 \\
\hline $\mathbf{2}$ & 7.03 & 6.94 & 7.20 & 7.30 & 7.80 \\
\hline $\mathbf{3}$ & 6.84 & 7.15 & 7.28 & 7.35 & 7.75 \\
\hline $\mathbf{4}$ & 7.04 & 7.10 & 7.40 & 7.45 & 7.70 \\
\hline $\mathbf{5}$ & 7.30 & 7.30 & 7.40 & 7.40 & 7.56 \\
\hline $\mathbf{6}$ & 7.22 & 7.20 & 7.45 & 7.48 & 7.78 \\
\hline $\mathbf{7}$ & 7.25 & 7.30 & 7.40 & 7.45 & 7.82 \\
\hline $\mathbf{8}$ & 7.33 & 7.57 & 7.52 & 7.52 & 7.82 \\
\hline $\mathbf{9}$ & 7.14 & 7.14 & 7.49 & 7.58 & 7.85 \\
\hline $\mathbf{1 0}$ & 7.15 & 7.35 & 7.40 & 7.40 & 7.80 \\
\hline
\end{tabular}


ANEXO 5 - Valores do pH do cimento óxido de zinco e eugenol

\begin{tabular}{|c|c|c|c|c|c|}
\hline & $\mathbf{2 4 h}$ & $\mathbf{4 8 h}$ & $\mathbf{7 d}$ & $\mathbf{1 4 d}$ & 30d \\
\hline $\mathbf{1}$ & 6.77 & 7.00 & 7.00 & 7.20 & 7.00 \\
\hline $\mathbf{2}$ & 6.75 & 7.00 & 7.03 & 7.17 & 7.15 \\
\hline $\mathbf{3}$ & 6.80 & 6.98 & 6.85 & 7.18 & 7.10 \\
\hline $\mathbf{4}$ & 6.85 & 7.02 & 7.00 & 7.17 & 7.10 \\
\hline $\mathbf{5}$ & 6.97 & 7.05 & 7.03 & 7.16 & 7.10 \\
\hline $\mathbf{6}$ & 6.79 & 6.95 & 6.90 & 7.14 & 7.10 \\
\hline $\mathbf{7}$ & 6.99 & 7.05 & 7.00 & 7.13 & 7.15 \\
\hline $\mathbf{8}$ & 6.99 & 7.05 & 7.00 & 7.17 & 7.10 \\
\hline $\mathbf{9}$ & 7.00 & 7.00 & 6.98 & 7.13 & 7.10 \\
\hline $\mathbf{1 0}$ & 6.99 & 7.04 & 7.00 & 7.10 & 7.12 \\
\hline
\end{tabular}


ANEXO 6 - Valores da liberação de cálcio em mg\% do cimento AH Plus com 10\% de hidróxido de cálcio

\begin{tabular}{|c|c|c|c|c|c|}
\hline & $\mathbf{2 4 h}$ & $\mathbf{4 8 h}$ & $\mathbf{7 d}$ & $\mathbf{1 4 d}$ & $\mathbf{3 0 d}$ \\
\hline $\mathbf{1}$ & 0.16 & 0.17 & 0.20 & 0.45 & 0.50 \\
\hline $\mathbf{2}$ & 0.16 & 0.18 & 0.21 & 0.38 & 0.45 \\
\hline $\mathbf{3}$ & 0.15 & 0.20 & 0.20 & 0.40 & 0.45 \\
\hline $\mathbf{4}$ & 0.18 & 0.16 & 0.20 & 0.40 & 0.45 \\
\hline $\mathbf{5}$ & 0.18 & 0.16 & 0.22 & 0.38 & 0.43 \\
\hline $\mathbf{6}$ & 0.18 & 0.18 & 0.20 & 0.41 & 0.45 \\
\hline $\mathbf{7}$ & 0.15 & 0.20 & 0.23 & 0.38 & 0.45 \\
\hline $\mathbf{8}$ & 0.16 & 0.20 & 0.22 & 0.38 & 0.46 \\
\hline $\mathbf{9}$ & 0.18 & 0.19 & 0.22 & 0.41 & 0.49 \\
\hline $\mathbf{1 0}$ & 0.18 & 0.20 & 0.20 & 0.38 & 0.46 \\
\hline
\end{tabular}


ANEXO 7 - Valores da liberação de cálcio em mg\% do cimento AH Plus com 5\% de hidróxido de cálcio

\begin{tabular}{|c|c|c|c|c|c|}
\hline & $\mathbf{2 4 h}$ & $\mathbf{4 8 h}$ & $\mathbf{7 d}$ & $\mathbf{1 4 d}$ & $\mathbf{3 0 d}$ \\
\hline $\mathbf{1}$ & 0.16 & 0.16 & 0.16 & 0.28 & 0.38 \\
\hline $\mathbf{2}$ & 0.16 & 0.16 & 0.16 & 0.30 & 0.43 \\
\hline $\mathbf{3}$ & 0.14 & 0.15 & 0.15 & 0.25 & 0.38 \\
\hline $\mathbf{4}$ & 0.12 & 0.12 & 0.14 & 0.28 & 0.38 \\
\hline $\mathbf{5}$ & 0.16 & 0.15 & 0.15 & 0.28 & 0.36 \\
\hline $\mathbf{6}$ & 0.10 & 0.11 & 0.13 & 0.25 & 0.35 \\
\hline $\mathbf{7}$ & 0.12 & 0.12 & 0.12 & 0.25 & 0.35 \\
\hline $\mathbf{8}$ & 0.12 & 0.12 & 0.14 & 0.26 & 0.32 \\
\hline $\mathbf{9}$ & 0.12 & 0.11 & 0.15 & 0.27 & 0.33 \\
\hline $\mathbf{1 0}$ & 0.12 & 0.12 & 0.14 & 0.25 & 0.30 \\
\hline
\end{tabular}


ANEXO 8 - Valores da liberação de cálcio em mg\% do cimento AH Plus puro

\begin{tabular}{|c|c|c|c|c|c|}
\hline & $\mathbf{2 4 h}$ & $\mathbf{4 8 h}$ & $\mathbf{7 d}$ & $\mathbf{1 4 d}$ & $\mathbf{3 0 d}$ \\
\hline $\mathbf{1}$ & 0.12 & 0.10 & 0.10 & 0.13 & 0.13 \\
\hline $\mathbf{2}$ & 0.10 & 0.10 & 0.10 & 0.13 & 0.13 \\
\hline $\mathbf{3}$ & 0.10 & 0.10 & 0.10 & 0.15 & 0.15 \\
\hline $\mathbf{4}$ & 0.11 & 0.11 & 0.10 & 0.10 & 0.10 \\
\hline $\mathbf{5}$ & 0.12 & 0.12 & 0.11 & 0.13 & 0.13 \\
\hline $\mathbf{6}$ & 0.11 & 0.12 & 0.10 & 0.11 & 0.11 \\
\hline $\mathbf{7}$ & 0.09 & 0.10 & 0.10 & 0.11 & 0.11 \\
\hline $\mathbf{8}$ & 0.09 & 0.10 & 0.12 & 0.11 & 0.11 \\
\hline $\mathbf{9}$ & 0.10 & 0.10 & 0.11 & 0.11 & 0.11 \\
\hline $\mathbf{1 0}$ & 0.09 & 0.10 & 0.11 & 0.11 & 0.11 \\
\hline
\end{tabular}


ANEXO 9 - Valores da liberação de cálcio em mg\% do cimento de óxido de zinco e eugenol

\begin{tabular}{|c|c|c|c|c|c|}
\hline & $\mathbf{2 4 h}$ & $\mathbf{4 8 h}$ & $\mathbf{7 d}$ & $\mathbf{1 4 d}$ & $\mathbf{3 0 d}$ \\
\hline $\mathbf{1}$ & 0.09 & 0.09 & 0.10 & 0.10 & 0.10 \\
\hline $\mathbf{2}$ & 0.09 & 0.09 & 0.10 & 0.10 & 0.10 \\
\hline $\mathbf{3}$ & 0.10 & 0.09 & 0.10 & 0.10 & 0.10 \\
\hline $\mathbf{4}$ & 0.09 & 0.09 & 0.10 & 0.10 & 0.10 \\
\hline $\mathbf{5}$ & 0.08 & 0.09 & 0.10 & 0.10 & 0.10 \\
\hline $\mathbf{6}$ & 0.09 & 0.09 & 0.09 & 0.10 & 0.10 \\
\hline $\mathbf{7}$ & 0.09 & 0.09 & 0.10 & 0.10 & 0.10 \\
\hline $\mathbf{8}$ & 0.09 & 0.09 & 0.10 & 0.10 & 0.10 \\
\hline $\mathbf{9}$ & 0.10 & 0.09 & 0.10 & 0.10 & 0.10 \\
\hline $\mathbf{1 0}$ & 0.09 & 0.09 & 0.10 & 0.10 & 0.10 \\
\hline
\end{tabular}




\section{REFERÊNCIAS BIBLIOGRÁFICAS}




\section{REFER $\hat{E} \mathcal{N C I}$ AS BI BLIOGRÁFICAS}

1. ABRAMOVICH, A.; GOLDBERG, F. The relationship of the root canal sealer to the dentine wall. An in vitro study using the Scanning Electron Microscope. J. Brit. Endod. Soc., v.9, n.2, p.81-6, 1976.

2. AHLBERG, K. M. F., ASSAVANOP, P.; TAY, W. M. A comparison of the apical dye penetration patterns shown by methylene blue and india ink in root-filled teeth. Int. Endod. J., v.28. n.1, p.30-4, Jan.1995.

3. ALAÇAM, T.; GÖRGÜL, G.; ÖMÜRLÜ, H. Evaluation of diagnostic radiopaque contrast materials used with calcium hydroxide. J. Endod, v.16, n.8, p.365-8, Aug. 1990.

4. ALAÇAM, T.; YOLDAS, O.; GÜLEN, O. Dentin penetration of 2 calcium hydroxide combinations. Oral Surg., v.86, n.4, p.469-72, Oct. 1998.

5. ALEXANDER, J. B.; GORDON, T. M. Acomparison of the apical seal produced by two calcium hydroxide sealers and a Grossman-type sealer when used with laterallymcondensed guta-percha.Quintess. Int., v.16, n.9, p.615-71, Sept. 1985.

6. ALLISON, D. A.; MICHELICH, R. J.; WALTON, R. E. The influence of master cone adaptation on the quality of the apical seal. J. Endod., v.7, n.2, p.61-5, Feb. 1981.

7. ALMEIDA, P.M.; ANTONIO, M.P. da S.; MOURA, A.A.M. de. Estudo comparativo da radiopacidade de quatro cimentos obturadores de canais radiculares. Rev. Inst. Ciênc. Saúde, v.16, n.1, p.27-30, Jan./June 1998.

\footnotetext{
*Normas recomendadas para uso no âmbito da Universidade de São Paulo, com base no documento "Referências Bibliográficas: exemplos", emanado do Conselho Supervisor do Sistema Integrado de Bibliotecas da USP, em reunião de 20 de setembro de 1990.
} 
8. ALMEIDA, W. A. de Cimentos obturadores de canais radiculares. Avaliação histológica da resposta dos tecidos apicais e periapicais em dentes de cães, após biopulpectomia. Estudo da infiltração apical. Araraquara, 1997. 190p. Tese (Doutorado) - Faculdade de Odontologia de Araraquara, Universidade Estadual Paulista "Júlio de Mesquita Filho".

9. AMERICAN DENTAL ASSOCIATION. Council on Dental Materials. Specification no 57 for endodontic filling material Chicago, 1984. p.147-169.

10. ANTHONY, D.R.; GORDON, T.M.; DEL RIO, C.E. The effect of three vehicles on the $\mathrm{pH}$ of calcium hydroxide. Oral Surg., v.54, n.5, p.560-5, Nov. 1982.

11. ANTONIO, M. P. do S.; MOURA, A. A. M. de Análise in vitro do selamento marginal apical de obturações realizadas com cones de guta-percha associada a quatro tipos de cimentos. Rev Odont. USP, v.11, n.1, p.616, jan./mar. 1997.

12. ANTONOPOULOS, K.G.; ATTIN, T.; HELLWIG, G. Evaluation of the apical seal of root canal fillings with different methods. J. Endod., v.24, n.10, p.655-8, Oct. 1998.

13. BAKHORDAR, R. A.; BUI, T.; WARANABE, L. An evaluation of sealing ability of calcium hydroxide sealers. Oral Surg.,v.68, n.1, p.88-92, July 1989.

14. BARTHEL, C. R. et al. Dye penetration in root canals filled with AH26 in different consistencies. J. Endod., v.20, n.9, p.436-44, Sept. 1994.

15. BELTES, P. et al. In vitro evaluation of the cytotoxicity of calcium hydroxidebased root canal sealers. Endod. dent. Traumat., v.11, n.5, p.245-9, Oct. 1995. 
16. BELTES, P.G. et al. In vitro release of hydroxyl ions from six types of calcium hydroxide nonsetting pastes. J. Endod., v.23, n.7, p.413-5, July 1997.

17. BENATTI , O.; STOLF, W.L.; RUHNKE, L.A. Verification of the consistency, setting time, and dimensional changes of root canal filling materials. Oral surg., v.46, n.1, p.107-13, July 1978.

18. BERBERT, A. Comportamento dos tecidos apicais e periapicais após biopulpectomia e obturação do canal com AH26, hidróxido de cálcio ou mistura de ambos. Estudo histológico em dentes de cães. Bauru, 1978. 174 p. Tese (Livre-Docência) - Faculdade de Odontologia de Bauru, Universidade de São Paulo.

19. BEYER-OLSEN, E.M.; ORSTAVIK, D. Radiopacity of root canal sealers. Oral surg., v.51, n.3, p.320-8, Mar. 1981.

20. BINNIE, W. H.; MITCHELL, D. F. Induced Calcification in the subdermal tissues of the rat. J. dent. Res., v.52, n.6, p.1087-91, Nov./Dec. 1973.

21. BIRMAN, E.G. et al. Estudo de propriedades físicas e biológicas de um cimento endodôntico àbase de hidróxido de cálcio. Rev. odont. USP, v.4, n.1, p.25-30, jan./mar. 1990.

22. BONETTI FILHO, I. et al. Capacidade seladora de novos cimentos obturadores. Através da infiltração do corante azul de metileno a $2 \%$. Rev. gaúcha Odont., v.43, n.4, p.221-4, jul./ago. 1995.

23. BOSCOLO, F.N.; BENATTI, O.; GONÇALVES, N. Estudo comparativo da radiopacidade dos cimentos obturadores de canais radiculares. Rev. Ass. paul. cirurg. Dent., v.33, n.2, p.154-60, mar./abr. 1979.

24. BOVIS, S. C.; HARRINGTON, E.; WILSON, H. J. Setting characteristics of composite filling materials. Brit dent. J., v.131, n.8, p.352-6, Oct.1971. 
25. BRAMANTE, A.S.; DuARTE, M. A. H.; BRAMANTE, M. A.H. Capacidade seladora do apexit, pró-canal e set sealer em obturações de canais. Rev. bras. Odont., v.53, n.3, p.5-7, maio/jun.1996.

26. ÇALT, S. et al. pH changes and calcion íon diffusion from calcium hydroxide dressing materials through root dentin. J. Endod., v.25, n.25, p.329-31, May 1999.

27. CARVALHO, E. M. O. F. de et al. Avaliação in vitro do selamento marginal apical de diferentes tipos de cimentos àbase de óxido de zinco e eugenol frente a vibração intra-radicular ultra-sônica. Rev. paul. Odont., v.17, n.2, p.34-5, mar./abr. 1995.

28. CERGNEUX, M. et al. The influence of the smear layer on the sealing ability of canal obturation. Int. Endod. J, v.20, n.5, p.228-32, Sept. 1987.

29. COCLETI, G. Avaliação da solução Kodak RPX-amat quando utilizada na processadora T4, da Dupont, quanto às densidades ótica e radiográfica, analisadas pelo fotodensitômetro MRA e pelo sistema digital Digora. Bauru, 1999. 88p. Tese (Doutorado) - Faculdade de Odontologia de Bauru, Universidade de São Paulo.

30. CURSON, I.; KIRK, E.E.J. An assessment of root canal-sealing cements. Oral surg., v.26, n.2, p.229-36, Aug. 1968

31. DEGEE, A.J.; WU, M.K.; WESSELINK, P.R. Sealing properties of Ketac-Endo glass ionomer cement and AH26 root canal sealers. Int. Endod. J., v.27, n.5, p. 239-44, Sept. 1994.

32. DOUGLAS, W. H.; ZAKARIASEN, K. L. Volumetric assessment of apical leakage utilizing a spectrophptometic, dye recovery method. J. dent. Res., v.60, n.1, p.438, Jan. 1981. Abstract 512 
33. DUARTE, M. A. H. Avaliação in vitro do poder anti-séptico e pH de diversos materiais empregados na prática endodôntica. Bauru, 1996 134p. Dissertação (Mestrado) - Faculdade de Odontologia de Bauru, Universidade de São Paulo.

34. ECONOMIDES, N. et al. Experimental study of the biocompatibility of four root canal sealers and their influence on the zinc and calcium content of several tissues. J. Endod., v.21, n.3, p.122-7, Mar. 1995.

35. ECONOMIDES, N. et al. Long-term evaluation of the influence of the smear layer on the sealing ability of different sealers. J. Endod., v.25, n.2, p. 123-5, Feb. 1999.

36. ELIASSON, S.T.; HAASKEN, B. Radiopacity of impression materials. Oral surg., v.47, n.5, p.485-91, May 1979.

37. ESBERARD, R.; CARNES, D.L.; DELRIO, C.E. Changes in $\mathrm{pH}$ at the dentin surface of roots obturated with calcium hydroxide pastes. J. Endod., v.22, n.8, p.402-5, Aug. 1996.

38. ESBERARD, R.; CARNES, D.L.; DELRIO, C.E. pH changes at the surface of root dentin when using root canal sealers containing calcium hydroxide. J. Endod., v.22, n.8, p.399-401, Aug. 1996.

39. ESTRELA, C.; PESCE, H. F. Chemical analysis of the liberation of calcium and hydroxyl ions from calcium hydroxide pastes in connective tissue in the dog - part I. Braz. dent. J., v.7, n.1, p.41-6, 1996.

40. ESTRELA, C.; PESCE, H. F. Chemical analisys of the formation of calcium carbonate and its influence on calcim hydroxide pastes in connective of the dog - part II. Braz. dent. J., v.8, n.1, p.49-53, 1997.

41. ESTRELA, C. et al. Estudo do efeito biológico do pH na atividade enzimática de bactérias anaerobias. Rev. Fac. Odont. Bauru, v.2, n.4, p.31-8, out./dez. 1994. 
42. ESTRELA, C. et al. Dentinal diffusion of hydroxyl ions of various calcium hydroxide pastes. Braz. dent. J., v.6, n.1, p.5-9, 1995.

43. ESTRELA, C. et al. Mechanism of action of calcium and hydroxylnions of calcium hydroxide on tissue and bacteria. Braz. dent. J., v.6, n.2, p.8590, 1995.

44. FIDEL, R.A.S. et al. Adhesion of calcium hydroxide-containing root canal sealers. Braz. dent. J., v.5, n.1, p.53-7, 1994.

45. FIDEL, R.A.S. et al. Estudo in vitro sobre a solubilidade e a desintegração de alguns cimentos endodônticos que contém hidróxido de cálcio. Rev. Odont. USP, v.8, n.3, p.217-20, jul./set. 1994.

46. FIDEL, R.A.S. et al. Estudo in vitro da estabilidade dimensional de alguns cimentos endodônticos contendo hidróxido de cálcio. Rev. bras. Odont., v.52, n.5, p.14-6, set./out. 1995.

47. FIDEL, R.A.S. et al. Tempo de endurecimento de alguns cimentos endodônticos que contém hidróxido de cálcio. ROBRAC, v.5, n.16, p.157, 1995.

48. FUSS, Z. et al. Intracanal pH changes of calcium hydroxide pastes exposed to carbon dioxide in vitro. J. Endod., v.22, n.7, p.362-4, July 1996.

49. GALE, M.S.; DARVELL, B.W. Dentine permeability and tracer tests. J. Dent., v.27, n.1, p.1-11, jan. 1999.

50. Gettleman, B.H.; MeSSER, H.H.; ElDEEB, M.E. Adhesión de los cementos selladores a la dentina con y sin barro dentinario. Endodoncia, v.9, n.2, p.83-91, abr./jun. 1991.

51. GOLDMAN , L. B. et al. Adaptation and porosity of poly-hema in a model system using two micoorganisms. J.Endod., v.6, n.9, p.683-6, Aug. 1980. 
52. GOLDMAN, M.; SIMMONDS, S.; RUSH, R. The usefulness of dyepenetration studies reexamined. Oral Surg, v.67, n.3, p.327-32, Mar.1989.

53. GORDON, T.M.; ALEXANDER, J.B. Influence on $\mathrm{pH}$ level of two calcium hydroxide root canal sealers in vitro. Oral Surg., v.60, n.6, p.624-8, June 1986.

54. GROSSMAN, L. I. A study of temporary fillimng as hermetic sealing agents. J. dent Res., v.18, n.1/2, p.67-71, Jan./Feb. 1939.

55. GROSSMAN, L.I. An improved root canal cement. J. Amer. dent. Ass., v.56, n.3, p.381-5, Mar. 1958.

56. GROSSMAN, L.I Physical properties of root canal cements. J. Endod., v.2, n.6, p.166-75, June 1976.

57. GROSSMAN, L.I Solubility of root canal cements. J. dent. Res., v.57, n.9/10, p.927, Sept./Oct. 1978.

58. GUIGAND, M. In vitro Study of intradentinal calcium diffusion induced by two endodontic biomaterials. J. Endod., v.23, n.6, p.387-90, June 1997.

59. HIGGINBOTHAM, T.L. A comparative study of the physical properties of five commonly used root canal sealers. Oral surg., v. 24, n.1, p.89-101, July 1967.

60. HOLLAND, R.; SOUZA, V. de. Ability of a new calcium hydroxide root canal filling material induce hard tissue formation. J. Endod., v.11, n.12, p.53543, Dec. 1985.

61. HOLLAND, R.; MURATA, S. S.; SALIBA, O. Efeito a curto e médio prazo dos resíduos de hidróxido de cálcio na qualidade do selamento marginal após a obturação de canal. Rev. paul. Odont., v.17, n.2, p.12-6. mar./abr. 1995. 
62. HOLLAND, R. et al. Sealing properties of some root filling materials evaluated with radioisotope. Aust. dent. J., v.19, n.5, p.322-5, Oct. 1974.

63. HOLLAND, R. et al. Infiltração marginal dos cimentos endodônticos. Rev. gaúcha Odont., v.39, n.6, p.413-6, nov./dez. 1991.

64. HOLLAND, R. et al. Infiltração marginal após o emprego do hidróxido de cálcio como curativo de demora. Rev. Odont. Unesp, v.22, n.2, p.49-55, jul./dez. 1993.

65. HOLLAND, R. et al. Análise do selamento marginal obtido com cimentos à base de hidróxido de cálcio. Rev. Ass. paul. cirug. Dent., v.50, n.1, p.61-4, jan./fev. 1996.

66. HOLLAND, $R$. et al. Apical leakage after root canal filling with an experimental calcium hydroxide guta-percha point. J. Endod., v.22, n.2, p.71-4, Feb. 1996.

67. HUANG, T.H.; KAD, C-T. pH Measurement of root canal sealers. J. Endod., v.24, n.4, p.236-8, Apr. 1998.

68. INTERNATIONAL ORGANIZATION FOR STANDARDIZATION. ISO $\mathrm{n}^{\circ}$. 6976.2. Dental root canal sealing, Geneve, 1998.

69. JACOBSON, S.; VON FRAUNHOFER, J. A. The investigation of microleakage in root canal therapy. An electrochemical technique. Oral Surg., v.42, n.6, p.817-23, Dec. 1976.

70. JOHNSON, N.T.; ZAKARIASEN, K.L. Spectrophotometric analysis of microleakage in the fine curved canals found in the mesial roots of mandibular molars. Oral Surg, v.56, n.3, p.305-9, Sept. 1983.

71. KAFFE, I et al. Is the radioopacity standard for guta-percha sufficient in clinical use? J. Endod., v.9, n.2, p.58-9, Feb. 1983. 
72. KAPSIMALIS, P.; EVANS, R. TUCKERMAN, M.M. Modified autoradiographic technique for marginal penetration studies. Oral Surg., v.20, n.4, p.494504, Oct. 1965.

73. KATZ, A. et al. Densitometric measurement of radiopacity of guta-percha cones and root dentin. J. Endod., v.16, n.5, p.211-3, May 1990.

74. KAUFMAN, A.V. et al. Life and AH26 as sealers in thermatically compacted guta-percha root canal fillings: leakage to a dye. J. Endod., v.15, n.2, p.68-71, Feb. 1989.

75. KAZEMI, K.B.; SAFAVI, K.E.; SPANGBERG, L.S.W. Dimensional changes of endodontic sealers. Oral surg., v.76, n.6, p.766-71, Dec. 1993.

76. KERSTEN, H.W.; MOORER, W.R. Particles and molecules in endodontic leakage. Int. Endod. J., v.22, n.3, p.118-24, May 1989.

77. KERSTEN, H. W. et al. A standardized leakage test with curved root canals in artificial dentine. Int. Endod. J., v.21, n.3, p.191-9, May 1988.

78. KING, K.T. et al. Longitudinal evaluation of the seal of endodontic retrofillings. J. Endod., v.16, n.7, p.307-10, July 1990.

79. KONTAKIOTIS, E. G.; WU, M.K.; WESSWLINK, P. R. Effect of calcium hydroxide dressing on seal of permanent root filiing. Endod. Dent. Traumat., v.13, n.5, p.281-4, Sept. 1995.

80. KUGA, M. C.; MORAES, I. G. de; BERBERT, A. Capacidade seladora do cimento sealapex puro ou acrescido de iodofórmio. Rev. Odont. USP, v.2, n.3, p.139-42, jul./set. 1988.

81. LAGE-MARQUES, J.L. et al. Avaliação da velocidade de dissociação iônica do hidróxido de cálcio associado a diferentes veículos. Rev. Odont. USP, v.8, n.2, p.81-7, abr./jun. 1994. 
82. LEAL, J.M. et al. Sealapex, AH26 silver free e fill canal. Avaliação in vitro do selamento apical através da infiltração do corante rodamina B a $2 \%$. Influência do tempo de armazenagem. Rev. bras. Odont., v.44, n.6, p.814, nov./dez. 1987.

83. LENGHEDEN, A. Influence of $\mathrm{pH}$ and calcium on growth and attachment of human fibroblasts in vitro. Scand. J. dent Res., v.102, n.2, p.130-6, Apr. 1994.

84. LEONARDO, M. R. et al. Hidróxido de cálcio em endodontia. Avaliação da alteração do $\mathrm{pH}$ e da liberação de íons de cálcio em produtos endodônticos a base de hidróxido de cálcio. Rev. gaúcha Odont., v.4, n.1, p.69-72, jan./fev. 1992.

85. LEONARDO, M.R. et al. Penetrabilidade do curativo de demora no sistema do canal radicular. Avaliação de diferentes produtos. Rev. gaúcha Odont., v.41, n.4, p.199-203, jul./ago. 1993.

86. LIM, K. C.; TIDMARSH, B. G. The sealing ability of sealapex compared with AH26. J. Endod., v.12, n.12, p.564-6, Dec.1986.

87. LIMKANGWALMONGKOL, S. et al. A comparative study of the apical leakage of four root canal sealeres and laterally condensed guta-percha. J. Endod., v.17, n.10, p.495-9, Oct. 1991.

88. LIMKANGWALMONGKOL, S.; ABBOT, P.V.; SANDLER, A.B. Apical dye penetration with four root canal sealers and guta-percha using longitudinal sectioning. J. Endod., v.18, n.11, p.535-9, Nov. 1992.

89. McCOMB, D.; SMITH, J.C. Comparison of physical properties of polycarboxylate-based and conventional root canal sealers. J. Endod., v.2, n.6, p.228-35, June 1976. 
90. MADISON, S.; ZAKARIASEN, K. L. Linear and volumetric analysis of apical leakage in teeth prepared for posts. J. Endod., v.10, n.9, p.422-7, Sept. 1984.

91. MADISON, S.; SWASON, K.; CHILES, S.A. Na evaluation of coronal microleakage in endodontically treated teeth. Part II. Sealer types. J. Endod., v.13, n.3, p. 109-12, Mar. 1987.

92. MAGURA, M. E. et al. Human saliva coronal microleakage in obturated root canals: an in vitro study. J. Endod., v.17, n.7, p.324-31, July 1991.

93. MANSON-HING, L. R. An investigation of the roentgenographic contrast of enamel, dentine, and aluminum. Oral surg., v.11, n.12, p.1456-72, Dec. 1961.

94. MARCIANO, J.; MICHAILESCO, P.M. Dental guta-percha: chemical composition, x-ray identification, enthalpic studies, and clinical implications. J. Endod., v.15, n.4, p.149-53, Apr. 1989.

95. MATLOFF, I.R. et al. A comparison of methods used in root canal sealability studies. Oral Surg., v.53, n.2, p.203-8, Feb. 1982.

96. MEDEIROS, J. M. F. de; PESCE, H. F.; MOURA, A. A. M. de Estudo comparativo da qualidade de selamento marginal propiciado por duas condições distintas de inserção do cimento obturador. Rev. Pós Grad., v.1, n.3, p.18-20, jul./set. 1994.

97. MERCK INDEX 12. ed., Whitehouse Station, Merck, 1996.

98. MORAES, I. G. de. Infiltração marginal nas obturações de canais radiculares em função de agentes irrigadores e cimentos obturadores. Bauru, 1981. 114p. Dissertação (Mestrado) - Faculdade de Odontologia de Bauru, Universidade de São Paulo. 
99. MORAES, I.G. de. Propriedades físicas de cimentos epóxicos experimentais para obturações de canais radiculares, baseados no AH26. Bauru, 1984. 149p. Tese (Doutorado) - Faculdade de Odontologia de Bauru, Universidade de São Paulo.

100. NEGM, M.M. The effect of human blood on sealing ability of root canal sealers: An in vitro study. Oral Surg., v.67, n.4, p.449-52, Apr. 1989.

101. NERWICH, A. et al. $\mathrm{pH}$ changes in root dentin over over a 4 week period following root canal dressing with calcium hydroxide. J. Endod., v.19, n.6, p.302-6, June 1993.

102. OLIVER, C.M.; ABBOTT, P.V. An in vitro study of apical and coronal microleakage of laterally condensed gutta percha with Ketac-endo and AH26. Aust. dent. J., v.43, n.4, p.262-8, Aug. 1998.

103. OLIVEIRA, A. S. de, et al. Efeitos histopatológicos do AH26, do $\mathrm{Ca}(\mathrm{OH})_{2}$ e de mistura de ambos em tecido subcutâneo de ratos. Rev. paul. Endod., v.1, n.3, p.4-16, jul./set. 1980.

104. ONO, K.; MATSMUTO, K. Physical Properties of CH61, a newly developed root canal sealer. J. Endod., v.24, n.4, p.244-7, Apr. 1998.

105. ORFALI, F.; LILLEY, J. D.; MOLOKHIA, A. The radiopacity of some endodontic sealer cements. J. Dent Res., v.66, n.4, p.876, Apr. 1987. Abstract 368

106. ORSTAVIK, D.; ERIKSEN, H. M.; BEYER-OLSEN, E. M. Adhesive properties and leakage of root canal sealers in vitro. Int. Endod. J., v.16, n.1, p.59-63, Jan. 1983.

107. PANTHOMVANICH, S.; EDMUNDS, D. A. Variations in the microleakage produced by four different techniques in root fillings in a simulated root canal model. Int. Endod. J., v.29, n.3, p.156-62, May 1996. 
108. PENICHE, C. E. C.; SAMPAIO, J. M. P.; COLLESI, R. R. Verificação do pH de diversas soluções àbase de hidróxido de cálcio. Rev. Odont. Univ. Santo Amaro, v.1, n.1, p.5-8, jan./jun. 1996.

109. PETRY, A.E.A. et al. Evaluation of endodontic sealer radiopacity using digitized imaging equipment. Braz. Endod., v.2, n.1, p.24-8, 1997.

110. PITT FORD, T.R. The leakage of root fillings using glass ionomer cement and other materials. Brit. dent J., v.146, n.1, p.273-8, May. 1979.

111. PITT FORD, T. R. Relation between seal of root filling and tissue response. Oral Surg., v.55, n.3, p.291-4, Mar.1983.

112. POLLARD, B.K.; WELLER, R.N.; KULILD, J.C. A standardized technique for linear dye leakage studies: immediate versus delayed immersion times. Int. Endod. J., v.23, n.5, p.250-3, Sept. 1990.

113. PORKAEW, P. et al. Effects of calcium hydroxide paste as an intracanal medicament on apicla seal. J. Endod., v.16, n.8, p.369-74, Aug. 1990.

114. RAY, H.; SELTZER, S. A new glass lonomer root canal sealer. J. Endod., v.17, n.12, p.598-603, Dec. 1991.

115. REHMAN, K. et al. Calcium íon diffusion from calcium hydroxide containing materials in endodontically - treated teeth: An in vitro study. Int. Endod. J., v.29, n.4, p.271-9. July 1996.

116. SAHLI, C.C. et al. The apical seal of root canal sealing cements using a radionuclide detection technique. Int. Endod. J., v.25, n.5, p.250-6, Sept. 1992.

117. SAMPAIO, J.M.P.; SATO, E.F.L. Avaliação da fluidez de vários materiais obturadores de canais radiculares. Rev. Inst. Odont. paul., v.2, n.1, p.1-5, jan./jun. 1984. 
118. SAUNDERS, E.M.; SAUNDERS, W.P. Long-term coronal leakage of JS Quickfill root fillings with Sealapex and Apexit sealers. Endod. dent. Traumat., v.11, n.4, p.181-5, aug. 1995.

119. SAVIOLI, R.N.; SILVA, R.G.; PÉCORA, J.D. Influência de cada componente do cimento de Grossman sobre as propriedades físicas de escoamento. Tempo de endurecimento e espessura do filme. Rev. paul. Odont., v.16, n.3, p.14-6, maio/jun. 1994.

120. SATO, E.F.L.; SAMPAIO, J.M.P. Avaliação da adesividade existente entre a dentina e três diferentes cimentos obturadores de canais radiculares. Rev. paul. Odont., v.7, n.3, p.20-32, maio/jun. 1985.

121. SCHUURS, A. H. B. et al. Endodontic leakage studies reconsidered. Part II. Statistical aspects. Int. Endod. J., v.26, n.1, p.44-52, Jan. 1993.

122. SEM, B.H.; PISKIN, B.; BARAN, N. The effect of tubular penetration of root canal sealers on dye microleakage. Int. Endod. J., v.29, n.1, p.23-8, Jan. 1996.

123. SEUX, D. et al. Odontoblast-like cytodifferentiation of human dental pulp "in vitro" in the presence of a calcium hydroxide-containing cement. Arch. Oral Biol., v.36, n.2, p.117-28, Feb. 1991.

124. SHAH, P.M.M. et al. Radiopacity of potencial root-end filling materials. Oral surg., v.81, n.4, p.476-9, Apr. 1996.

125. SILVA, L. A. B. da et al. Calcium hydroxide root canal sealers: evaluation of $\mathrm{pH}$, calacium íon concentration and conductivity. Int. Endod. J., v.30, n.3, p.205-9, May 1997.

126. SIMON, S.T.; BHAT, K.S; FRANCIS, R. Effect of four vehicles on the $\mathrm{pH}$ of calcium hydroxide and the release of calcium íon. Oral Surg., v.80, n.4, p.459-64, Oct.1995. 
127. SIQUEIRA JÚNIOR; J.F.; FRAGA, R.C.; GARCIA, P.F. Evaluation of sealing ability $\mathrm{pH}$ and flow rate of three calcium hydroxide-based sealers. Endod. dent. Traumat., v.11, n.5, p.225-8, Oct. 1995.

128. SIQUEIRA JUNIOR., J.F. et al. Coronal Leakage of two root canal sealers containing calcium hydroxide after exposure to human saliva. J. Endod., v.25, n.1, p.14-6, Jan. 1999.

129. SMITH, M. A.; STEIMAN, H. R. An in vitro evaluation of microleakage of two new and two old root canal sealers. J. Endod., v.20, n.1, p.18-21, Jan. 1994.

130. SPÁNGBERG, L. S. W.; ACIERNO, T. G.; CHA, B. C. Influence of entrapped air on the accuracy of leakage studies using dye penetration methods. J. Endod., v.15, n.11, p.548-51, Nov.1989.

131. STAEHLE, $\mathrm{H}$. J. et al. Effect of root canal filling materials containing calcium hydroxide on the alkalinity of root dentin. Endod. dent. Traumat., v.11, n.4, p.163-8, Aug. 1995.

132. StAMOS, D. G.; HAASCH, G. C.; GERSTEIN, H. The pH of local anesthetic/calcium hydroxide solutions. J. Endod., v.6, n.11, p264-265, June 1995.

133. STARKEY, D. L.; ANDERSON, R. W.; PASHLEY, D. H. An evaluation of the effect of methylene blue dye pH on apical leakage. J.Endod., v.19, n.9, p.435-9, Sept. 1993.

134. TAGGER, M.; TAGGER, E. Periapical reactions to calcium hydroxidecontaining sealers and AH26 in monkeys. Endod. dent. Traumat., v.5, n.3, p.139-46, June 1989.

135. TAGGER, M.; TAGGER, E.; KFIR, A. Release of calcium and hydroxyl ions from set endodontic sealers containing calcium hydroxide. J. Endod., v.14, n.12, p.588-91, Dec. 1988. 
136. TAGGER, M. et al. An improved method of three-dimensional study of apical leakage. Quintessence Int., v.14., n.10, p.1-6, Oct. 1983.

137. TAMBURIC, S.D.; VULETA G.M.; OGNJANOVIC. J.M. In vitro release of calcium and hydroxyl ions from too types of calcium hydroxide preparation. Int. Endod. J., v.26, n.2, p.125-30, Mar. 1993.

138. TANOMARU FILHO, M. et al. Avaliação do selamento apical de dois cimentos obturadores àbase de hidróxido de cálcio . Rev. bras. Odont., v. 53, n.3, p.2-4, maio/jun. 1996.

139. TORABINEJAD, M.; UNG, B.; KETTERING, J.D. In vitro bactéria penetration of coronally unsealed endodontically treated teeth. $\mathbf{J}$. Endod., v.16, n.12, p.566-9, Dec. 1990.

140. TORABINEJAD, M. et al. Physical and chemical properties of a new root end filling material. J.Endod., v.21, n.7, p.349-53, July 1995.

141. TRONSTAD, L.; BARNETT, F; FLAX, M. Solubility and biocompatibility of calcium hydroxide-containing root canal sealers. Endod. dent. Traumat., v.4, n.4, p.152-9, Aug. 1988.

142. TRONSTAD, L. et al. $\mathrm{pH}$ changes in dental tissues after root canal filling with calcium hydroxide. J. Endod., v.7, n.1, p.17-21, Jan. 1981.

143. WAKABAYASHI, $\mathrm{H}$. et al. Bio-microscopical observation of dystrophic calcification induced by calcium hydroxide. Endod. dent. Traumat., v.9, n.4, p.165-70, Aug. 1993.

144. WANG, J.D.; HUME, W.R. Diffusion of hydrogen íon and hydroxyl íon from various sources through dentine. Int. Endod. J., v.21, n.1, p.17-26, Jan. 1988.

145. WEISMAN, M.I. A study of the flow rate of tem root canal sealers. Oral Surg., v.29, n.2, p.255-61, Feb. 1970. 
146. WIENER, B.H.; SCHILDER, H. A comparative study of important physical properties of various root canal sealers. Oral surg., v.32, n.5, p.768-77, Nov. 1972.

147. WU, M. K.; WESSELINK, P. R. Endodontic leakage studies reconsidered. Part I. Methodology, aplication and relevance. Int. Endod. J., v.26, n.1, p.37-43, Jan.1993.

148. WU, M.K.; DE GEE, A.J.; WESSELINK, P.R. Fluid transport and dye penetration along root canal fillings. Int. Endod. J., v.27, n.5, p.233-8, Sept. 1994.

149. WU, M.K.; DE GEE, A.J.; WESSELINK, P.R. Leakage of four root canal sealers at different thicknesses. Int. Endod. J., v.27, n.6, p. 304-8, Nov. 1994.

150. WU, M.K.; KONTAKIOTIS, E.G.; WESSELINK, P.R. Decoloration of $1 \%$ methylene blue solution in contact with dental filling materials. J. Dent., v.26, n.7, p. 585-9, Sept. 1998.

151. WU, M. K. et al. Fluid transport and bacteial penetration along root canal fillings. Int. Endod. J., v.26, n.3, p.203-8, May 1993.

152. YESILSOY, C. et al. A comparative tissue toxicity evaluation of established and newer root canal sealers. Oral surg., v.65, n.4, p.459-67, Apr. 1988.

153. ZAKARIASEN, K. L.; DOUGLAS, W. H.; STADEM, P. Comparison of volumetric and linear measurements of root canal leakage. J. dent. Res., v.60, n.1, p.627, Jan. 1981. Abstract 1273

154. ZMENER, O. Evaluation of the apical seal obtained with two calcium hydroxide based endodontic sealers. Int. Endod. J., v.20, n.2, p.87-90, Mar. 1987. 
155. ZMENER, O. et al. Sealing ability properties of a new epoxy resin-based root-canal sealer. Int. Endod. J., v.30, n.5, p.332-4, Sept. 1997.

156. ZYTKIEVITZ, E.; LIMA, J.L.M. de A.; SOBRINHO, J.B. Tempo de presa e escoamento de alguns cimentos obturadores de canais radiculares. Odont. mod., v.12, n.10, p.32-41, nov./dez. 1985. 
ABSTRACT 


\section{$\mathcal{A B S} \mathcal{T} R \mathcal{A C T}$}

Some physico-chemical properties as radiopacity, cure time, flow, $\mathrm{pH}$, calcium release, and apical leakage of $\mathrm{AH}$ Plus plain or modified were analyzed and compared in vitro to the ones of zinc oxide eugenol. The changes performed in the Ah-plus cement implied in a $5 \%$ and $10 \%$ increase of calcium hydroxide in weight. For the radiopacity analysis, the cements were placed in $10 \mathrm{~mm}$ diameter and $2 \mathrm{~mm}$ hight rings according to the $\mathrm{n}-57$ ADA norm and the values determination were given by the Digora digital image system and latter converted in $\mathrm{mm}$ of Al. For the cure time test, the cements were also placed in metal rings and with the aid of a Gilmore needle weighing 453.6 it was determined the final cure time. In the flow assessment, the cements were prepared and $0,5 \mathrm{~mL}$ of them were placed on a glass slab and, immediately, another slab with a weight totalizing $120 \mathrm{gr}$ was placed on the cement and after 10 minutes the largest and smaller cement diameter was measured and the average of both was considered the flow value. For the assessment of apical leakage, human canine or cuspid teeth had their canals instrumented and the external surfaces impermealized before proceding the obturation by the simple cone technique with the cements under study. In sequence the teeth were immersed in methilene blue $2 \%$ during 7 days. After this period, the teeth were removed from the die, washed, scrubbed, seccioned and the marker leakage was determined in an optical microscope with micrometered ocular. For the $\mathrm{pH}$ and calcium release assessment, the cements were placed in tubes measuring $1 \mathrm{~cm}$ in length and $1 \mathrm{~mm}$ in diameter and later immersed in $20 \mathrm{~mL}$ of deionized water. Measurements were made in 24 hours, 48 hours, 7 days, 14 days and 30 days, when $4 \mathrm{~mL}$ of the solution were removed to assess the $\mathrm{pH}$ with the aid of a pHmeter, and the calcium release through a spectrophometer of atomic absorption. The results showed that the increase of calcium hydroxide to the $\mathrm{AH}$ Plus cement did not significantly interfere in the radiopacity, did not alter the cure time, improved the flow, specially with the addition of $5 \%$, significantly favored the apical sealing and provided a more alcaline 
$\mathrm{pH}$, as well as calcium íons release. As to the plain AH Plus, it was evidenced a low apical sealing and a very high flow rate. 